COMPORTAMENTO BIOCLIMÁTICO DE MATRIZES SUÍNAS EM GESTAÇÃO E O USO DE SISTEMAS INTELIGENTES NA CARACTERIZAÇÃO DO AMBIENTE PRODUTIVO: SUINOCULTURA DE PRECISÃO

\author{
HÉLITON PANDORFI
}

Tese apresentada à Escola Superior de Agricultura

"Luiz de Queiroz", Universidade de São Paulo, para obtenção do título de Doutor em Agronomia, Área de Concentração: Física do Ambiente Agrícola

P I R A C I C A B A

Estado de São Paulo - Brasil

Junho - 2005 
COMPORTAMENTO BIOCLIMÁTICO DE MATRIZES SUÍNAS EM GESTAÇÃO E O USO DE SISTEMAS INTELIGENTES NA CARACTERIZAÇÃO DO AMBIENTE PRODUTIVO: SUINOCULTURA DE PRECISÃO

\author{
HÉLITON PANDORFI \\ Engenheiro Agrônomo
}

Orientador: Prof. Dr. IRAN JOSÉ OLIVEIRA DA SILVA

\begin{abstract}
Tese apresentada à Escola Superior de Agricultura
"Luiz de Queiroz", Universidade de São Paulo, para obtenção do título de Doutor em Agronomia, Área de Concentração: Física do Ambiente Agrícola
\end{abstract}

P I R A C I C A B A

Estado de São Paulo - Brasil

Junho - 2005 
Dados Internacionais de Catalogação na Publicação (CIP) DIVISÃO DE BIBLIOTECA E DOCUMENTAÇÃO - ESALQ/USP

\section{Pandorfi, Héliton}

Comportamento bioclimático de matrizes suínas em gestação e o uso de sistemas inteligentes na caracterização do ambiente produtivo: suinocultura de precisão / Héliton Pandorfi. - - Piracicaba, 2005

119 p. : il.

Tese (doutorado) - - Escola Superior de Agricultura Luiz de Queiroz, 2005. Bibliografia.

1. Bioclimatologia animal 2. Confinamento animal 3. Conforto térmico das construções 4. Matrizes animais 5. Prenhez 6. Sistema de produção 7. Sistemas inteligentes 8. Suinocultura de precisão I. Título 
Aos meus pais, Hélio e Lourdes.

As palavras nunca serão suficientes para expressar a gratidão e o respeito que tenho para com aqueles que não só me deram a vida, como também orientaram meus passos.

Foi por vocês que cheguei até aqui. É por vocês que seguirei em frente!

MINHA HOMENAGEM

A minha esposa, Cristiane Guiselini, pelo amor, cumplicidade, apoio, carinho $e$ incentivo, e aos meus filhos Pamela e Victor, grandes motivadores de tudo.

OFEREÇO E DEDICO 


\section{AGRADECIMENTOS}

A Deus, que me iluminou e me deu forças nos momentos em que mais precisei para vencer os obstáculos surgidos durante esse percurso.

À Escola Superior de Agricultura "Luiz de Queiroz", pelas tantas oportunidades oferecidas.

Ao Professor Dr. Iran José Oliveira da Silva, pela orientação, amizade, confiança, incentivo e entusiasmo na execução deste trabalho, responsável pelo meu crescimento pessoal e científico.

Ao Sr. Paulo Cesar Micheloni, gerente da granja Querência e a todos os seus funcionários, pela atenção, confiança, sugestões e colaboração para o desenvolvimento deste trabalho, viabilizando a instalação e execução do experimento a campo.

Aos Professores do Programa de Pós-Graduação em Física do Ambiente Agrícola, pelos ensinamentos e oportunidade de realização do curso.

Aos Professores Luiz Roberto Angelocci, Daniella Jorge de Moura, Valdomiro Shigueru Miyada, pelos ensinamentos, sugestões para a melhoria e engrandecimento deste trabalho.

À Professora Sônia Maria de Stefano Piedade, pelo auxílio na definição e execução das análises estatísticas.

Ao Professor Dr. Ernane José Xavier da Costa, pelo apoio e sugestões na aplicação das ferramentas computacionais neste trabalho.

Ao colega Jefferson Luiz de Carvalho, pelo incansável apoio na instalação e condução do experimento a campo. 
A minha esposa Cristiane Guiselini, pelo apoio e companheirismo na análise de dados e edição da tese.

Aos colegas do Núcleo de Pesquisa em Ambiência, Mauríco Perissinotto, José Antonio Delfino Barbosa Filho, Edilaine Regina Pereira, Aurélio Telatin Junior, Euclides Foroni Neto, Ligia Carvalho Cordeiro, Maristela N. da Conceição, Sulivan Pereira Alves, Wagner de Oliveira, Ivana Ferreira, pela amizade e apoio direto e indireto na realização deste trabalho.

Aos colegas do Curso de Pós-Graduação em Física do Ambiente Agrícola, pelo convívio e amizade durante a realização do curso.

À Fundação de Amparo à Pesquisa - FAPESP, pelo financiamento para a realização desta pesquisa.

À Coordenação de Aperfeiçoamento de Pessoal de Nível Superior (CAPES) pela concessão da bolsa de estudos. 


\section{SUMÁRIO}

Página

LISTA DE FIGURAS …................................................................................... ix

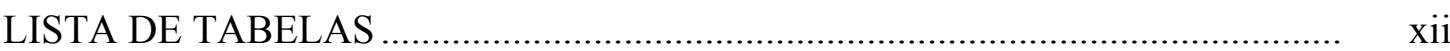

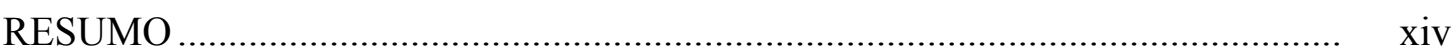

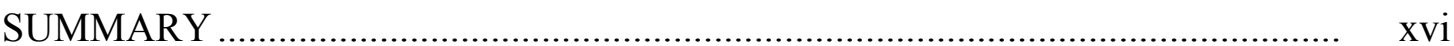

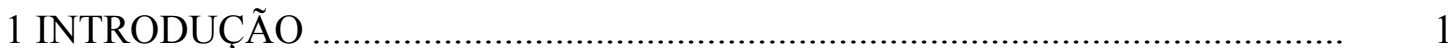

2 REVISÃO DE LITERATURA …….......................................................... 5

2.1 Aspectos relacionados à bioclimatologia animal ............................................... 5

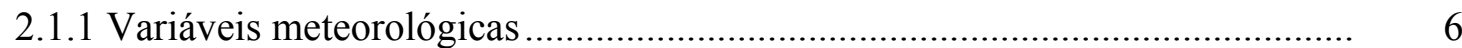

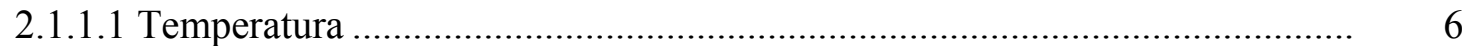

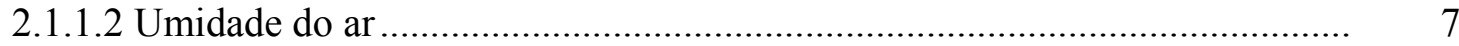

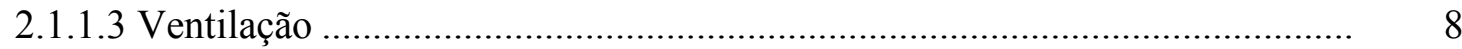

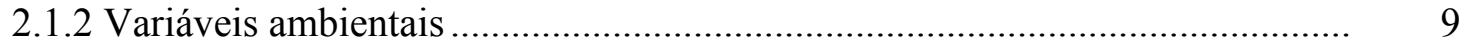

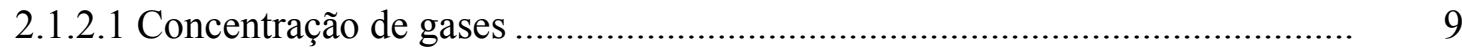

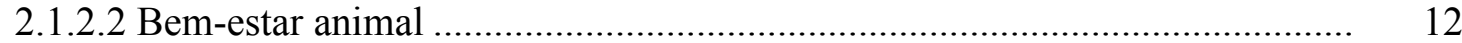

2.2 Sistemas de produção ....................................................................................... 17

2.2.1 Alojamento em baias individuais ................................................................. 22

2.2.2 Alojamento em baias coletivas......................................................................... 24

2.3 Sistemas inteligentes aplicados à suinocultura …............................................... 25 
2.3.1 Identificação eletrônica .......................................................................... 25

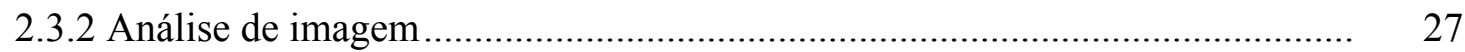

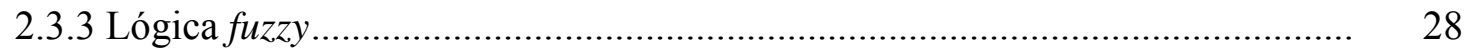

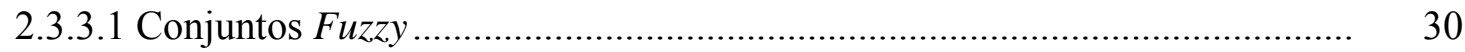

2.3.4 Redes Neurais Artificiais .............................................................................. 31

2.3.4.1 Uso das redes neurais artificiais na agropecuária ....................................... 34

3 MATERIAL E MÉTODOS ........................................................................ 36

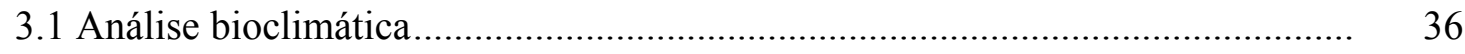

3.1.1 Variáveis meteorológicas ........................................................................ 36

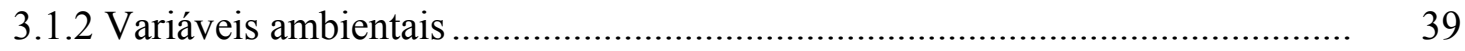

3.1.3 Tipologia da instalação estudada ..................................................................... 39

3.2 Análise dos sistemas de produção...................................................................... 41

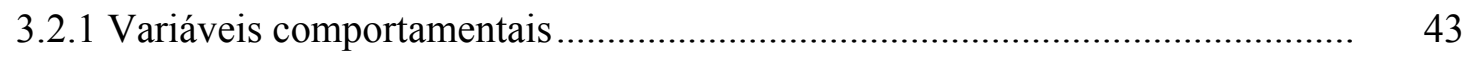

3.2.1.1 Sistema de monitoramento comportamental .......................................... 45

3.2.2 Variáveis fisiológicas e índices zootécnicos ............................................ 47

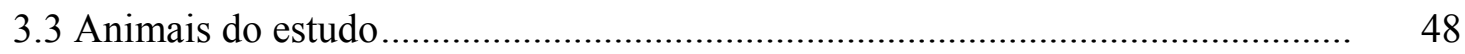

3.3.1 Manejo dos Animais .............................................................................. 49

3.4 Aplicação de sistemas inteligentes disponíveis para o estudo de padrões de conforto e predição dos índices zootécnicos ................................................. 50

3.4.1 Lógica Fuzzy ............................................................................... 50

3.4.2 Redes Neurais Artificiais (RNAs) ……....................................................... 54

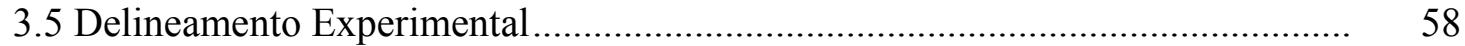

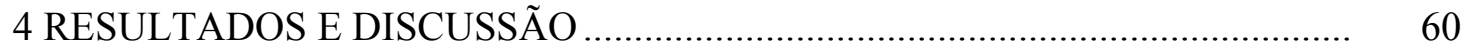


4.1 Análise bioclimática

4.1.1 Variáveis meteorológicas e índices de conforto................................................. 60

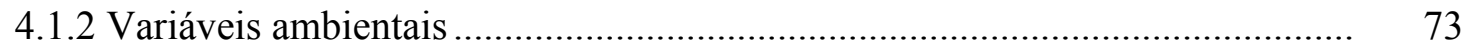

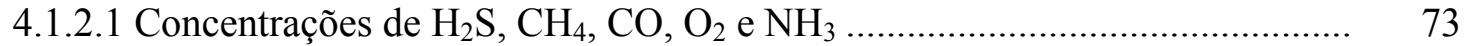

4.2 Análise dos sistemas de produção ..................................................................... 77

4.2.1 Parâmetros fisiológicos ..................................................................................... 77

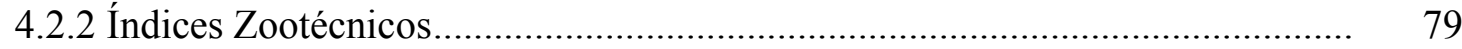

4.2.3 Análise comportamental........................................................................... 82

4.3 Lógica fuzzy aplicada às determinações de conforto para matrizes gestantes ..... 93

4.3.1 Uso da rede neural artificial para predição dos índices zootécnicos................. 100

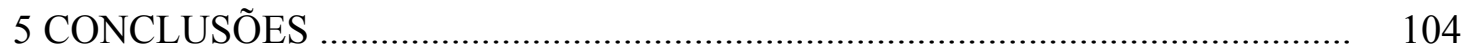

REFERÊNCIAS BIBLIOGRÁFICAS ............................................................. 106 


\section{LISTA DE FIGURAS}

Página

1 Modelo genérico do neurônio artificial................................................................ 32

2 Disposição do microprocessador para o registro das variáveis meteorológicas na condição de alojamento em baias coletivas (a) e baias individuais (b).................. 37

3 Anemômetro e microprocessador blindado instalados no ambiente externo à instalação

4 Visualização do medidor de gases utilizado no experimento.

5 Representação esquemática da distribuição dos tratamentos, baias individuais e coletivas no interior da instalação

6 Sistema de confinamento em baias individuais

7 Sistema de confinamento em baias coletivas.

8 Fluxograma das variáveis respostas dos diferentes sistemas de confinamento estudados, baias individuais (T1) e coletivas (T2)

9 Visualização da microcâmera utilizada no experimento (a) e instalada no local do estudo (b)

10 Visualização da tela do software de captura das imagens.

11 Esquema geral da distribuição das matrizes em seus respectivos tratamentos.....

12 Arquitetura da rede empregada no treinamento

13 Variação da temperatura média diária nos diferentes tratamentos na sala de gestação e no ambiente externo 
14 Variação da temperatura média horária para os dias críticos de maior (a) e menor (b) entalpia nos diferentes tratamentos na sala de gestação e no ambiente externo.

15 Variação da umidade relativa média diária nos diferentes tratamentos na sala de gestação e no ambiente externo

16 Variação da umidade relativa média horária para o dia de maior (a) e menor (b) entalpia nos diferentes tratamentos na sala de gestação e no ambiente externo...

17 Variação da temperatura de globo negro média diária nos diferentes tratamentos na sala de gestação e no ambiente externo.

18 Variação da temperatura de globo negro média horária para o dia de maior (a) e menor (b) entalpia nos diferentes tratamentos na sala de gestação e no ambiente externo.

19 Variação média diária do índice de temperatura de globo negro e umidade nos diferentes tratamentos na sala de gestação e no ambiente externo.

20 Variação média horária do índice de temperatura de globo negro e umidade para o dia de maior (a) e menor (b) entalpia nos diferentes tratamentos na sala de gestação e no ambiente externo

21 Variação média diária da entalpia nos diferentes tratamentos na sala de gestação e no ambiente externo

22 Variação média horária da entalpia para o dia crítico superior (a) e inferior (b) nos diferentes tratamentos na sala de gestação e no ambiente externo.

23 Variação da concentração de amônia e da temperatura no interior da sala de gestação.

24 Relação funcional entre concentração de amônia $\left(\mathrm{NH}_{3}\right)$ e a variação da temperatura no interior da instalação.

25 Variação da concentração de amônia em relação à postura dos animais no interior da sala de gestação. 
26 Variação comportamental das matrizes alojadas em baias individuais (a) e coletivas (b) no horário das 8 às 9 horas.

27 Variação comportamental das matrizes alojadas em baias individuais (a) e coletivas (b) no horário das 12 às 13 horas.

28 Variação comportamental das matrizes alojadas em baias individuais (a) e coletivas (b) no horário das 16 às 17 horas.

29 Variação das atividades comportamentais e entalpia para os dois sistemas de contenção, baias individuais e coletivas.

30 Variação dos comportamentos estereotipados e entalpia para os dois sistemas de contenção, baias individuais e coletivas.

31 Variação das posturas e entalpia para os dois sistemas de contenção, baias individuais e coletivas.

32 Variação das interações sociais e entalpia para os dois sistemas de contenção, baias individuais e coletivas.

33 Conforto ambiental como função da temperatura e umidade relativa do ar.

34 Conforto ambiental como função da temperatura e a concentração de amônia.... 96

35 Conforto ambiental como função da temperatura e a taxa respiratória.

36 Conforto ambiental como função da entalpia $\left(\mathrm{kJ} \mathrm{kg}^{-1}\right)$ e da inatividade animal $(\%)$

37 Gráfico do andamento do treinamento da rede.

38 Relação funcional entre os dados normalizados para o peso no nascimento dos leitões medidos e os dados normalizados para o peso no nascimento estimado pela RNA (a) e sua variação na fase de teste e validação (b).

39 Relação funcional dos dados normalizados para o número de leitões mumificados medidos e os dados normalizados para o número de mumificados estimados pela RNA (a) e sua variação na fase de teste e validação (b). 


\section{LISTA DE TABELAS}

Página

1 Recomendação máxima de amônia $\left(\mathrm{NH}_{3}\right)$, sulfeto de hidrogênio $\left(\mathrm{H}_{2} \mathrm{~S}\right)$, monóxido de carbono $(\mathrm{CO})$ e dióxido de carbono $\left(\mathrm{CO}_{2}\right)$ em instalações para suínos

2 Etograma comportamental para matrizes gestantes alojadas em baias individuais e coletivas

3 Composição centesimal da ração basal.

4 Classificação do estado de conforto térmico como função da temperatura $\left({ }^{\circ} \mathrm{C}\right)$ e umidade relativa do ar (\%)

5 Classificação do estado de conforto térmico como função da temperatura $\left({ }^{\circ} \mathrm{C}\right)$ e a concentração de amônia $\left(\mathrm{NH}_{3}\right)$

6 Classificação do estado de conforto térmico como função da temperatura $\left({ }^{\circ} \mathrm{C}\right)$ e a taxa respiratória (mov. $\mathrm{min}^{-1}$ ).

7 Classificação do estado de conforto térmico como função da entalpia e a inatividade animal

8 Parâmetros de treinamento utilizados para o algoritmo backpropagation......

9 Valores médios diários das variáveis ambientais para o sistema de confinamento em baias coletivas (T1), baias individuais (T2) e no ambiente externo.

10 Concentração média horária dos gases $\mathrm{H}_{2} \mathrm{~S}, \mathrm{CO}, \mathrm{CH}_{4}, \mathrm{O}_{2}$ e $\mathrm{NH}_{3}$ no interior da sala de gestação.

11 Médias das variáveis fisiológicas no período experimental. 
12 Valores médios dos índices zootécnicos na fase de gestação e maternidade para os animais submetidos ao regime de confinamento em baias individuais e coletivas durante a gestação

13 Freqüência e porcentagem média da variação comportamental, atividade, estereotipia, interação social e agressiva das matrizes alojadas em sistemas de contenção em baias individuais e coletivas.

14 Freqüência e porcentagem média da variação comportamental de postura das matrizes alojadas em sistemas de contenção em baias individuais e coletivas......

15 Limite médio do conforto ambiental para matrizes gestantes determinado por meio da teoria dos conjuntos fuzzy e os valores médios registrados no estudo ...... 


\title{
COMPORTAMENTO BIOCLIMÁTICO DE MATRIZES SUÍNAS EM GESTAÇÃO E O USO DE SISTEMAS INTELIGENTES NA CARACTERIZAÇÃO DO AMBIENTE PRODUTIVO: SUINOCULTURA DE PRECISÃO
}

\author{
Autor: HÉLITON PANDORFI \\ Orientador: Prof. Dr. IRAN JOSÉ OLIVEIRA DA SILVA
}

\section{RESUMO}

O objetivo geral desta pesquisa consiste na avaliação de diferentes sistemas de alojamento para matrizes gestantes, visando caracterizar aspectos quantitativos e qualitativos do ambiente e as variáveis que influenciam o sistema de produção, determinando as condições favoráveis ao melhor desempenho animal, baseada nas respostas ao ambiente de criação. O experimento foi realizado no período compreendido entre 04/01 e 11/03/2005, em uma propriedade de produção industrial de suínos, localizada no município de Elias Fausto, estado de São Paulo. A pesquisa foi desenvolvida no setor de gestação, com 24 matrizes primíparas, 12 fêmeas alojadas em baias individuais (T1) e 12 animais em baias coletivas (T2) e posteriormente na maternidade, onde foram quantificados os índices de produção dos leitões provenientes do estudo. O trabalho foi dividido basicamente em três etapas, em função da forma de avaliação dos dados: análise bioclimática; análise dos sistemas de produção; 
avaliação de sistemas inteligentes disponíveis, lógica fuzzy e redes neurais artificiais (RNAs) para o estudo de padrões de conforto térmico ambiental e predição dos índices zootécnicos, peso no nascimento e número de leitões mumificados, com base nos dados de temperatura ambiente e taxa respiratória das matrizes. A avaliação bioclimática foi realizada por meio do registro das variáveis meteorológicas (temperatura ambiente, umidade do ar, temperatura de globo negro e velocidade do vento) e ambientais (concentração de gases), na sala de gestação e no ambiente externo, possibilitando a caracterização da eficiência térmica, pelos índices de temperatura de globo e umidade (ITGU) e entalpia específica (h) e da condição de salubridade da instalação. A análise do sistema de produção teve, como variáveis respostas aos tratamentos avaliados, as relações comportamentais, os parâmetros fisiológicos e os índices zootécnicos. O delineamento experimental foi em blocos casualizados, com dois tratamentos e 67 blocos, e as médias, comparadas pelo teste de Tukey. As variáveis meteorológicas e ambientais apontam o sistema de confinamento em baias coletivas como aquele que permitu melhor condicionamento térmico natural às matrizes em gestação. Com relação à concentração de gases, os teores médios não superaram as concentrações consideradas críticas para as matrizes. Os parâmetros fisiológicos e os índices zootécnicos apresentaram valores mais adequados para o T2, assim como seu reflexo no desempenho da parição dos leitões. A avaliação comportamental, realizada pelo monitoramento por meio do registro de imagens de vídeo, apontou menor incidência de comportamentos resultantes do estresse ambiental, estereotipias e interações agressivas referentes ao estabelecimento de uma organização social no T2 comparativamente ao T1. O uso da teoria dos conjuntos fuzzy permitiu que se fizesse uma alusão entre os dados resultantes do trabalho experimental com os estabelecidos pela literatura, por intermédio de uma base de regras estabelecidas, para a determinação do conforto ambiental aplicado a matrizes na fase de gestação. O sucesso das redes neurais esteve diretamente relacionado com a sua alta versatilidade, permitindo as aproximações propostas neste trabalho para a predição dos índices zootécnicos. 


\title{
BIOCLIMATIC BEHAVIOR OF PREGNANT SOWS AND USE OF INTELLIGENT SYSTEMS FOR PRODUCTION ENVIRONMENT CHARACTERIZATION: PRECISION SWINE BREEDING
}

\author{
Author: HÉLITON PANDORFI \\ Adviser: IRAN JOSÉ OLIVEIRA DA SILVA
}

\section{SUMMARY}

This study evaluated different housing systems for pregnant sows aiming to describe quantitative and qualitative aspects of environment, as well as variables that have effect on production system. The optimal conditions for animal performance improvement have been determined analyzing behavioral data took in breeding environment. Trial was carried out from january 4th to march 11th 2005 in a farm specialized in industrial production of pork, located in Elias Fausto City, São Paulo State. In gestation facility 24 gilts were allocated:12 in individual stalls (T1) and 12 in group housing (T2). Further, in farrowing housing, piglets were evaluated in relation to their production variables. Basicaly, this study was divided in three steps in function of the way chose for data analysis: bioclimatic analysis; analysis of the production systems; evaluation of the available intelligent systems: fuzzy logic and artificial neural nets (ANNs) for studing environmental thermal confort patterns and prediction of produtive indexes, birth weights and number of mummifed piglets, based on data of environmental 
temperature and sow respiratory rates. Bioclimatic evaluation was realized by registering metheorological variables (environmental temperature, air humidity, dark globe temperature and wind velocity) and environmental variables (concentration of gases) inside of parturition room and in external environment, which permitted to characterize thermal efficiency by indexes of globe temperature and humidity (IGTH) and specific enthalpy (h) and salubrious condition of facility. The analysis of production system had as variables the answers to treatments, the behavioral relationships, physiological parameters and productive indexes. Experimental design was randomized blocks with two treatments and 67 blocks. Means were compared by Tukey test. Metheorological and environmental variables indicated the confinement system in group-houses as that permitted the better natural thermal monitoring for pregnant gilts. In relation to concentration of gases, mean levels did not exceed the concentrations considered limitating for sows. Physiological parameters and productive indexes were more adequate in $\mathrm{T} 2$, which reflected in performance during parturition. Behavior evaluation, realized by image monitoring using video cameras, showed lower incidence of behaviors related to environmental stress, stereotypies and agressive interactions caused by social organization establishment within group-housing system. The fuzzy set theory permitted to compare experimental data with those reported in cientific papers through rules created for proportionating well-fare of sows during gestation period. The success of neural nets was directly related to it high versatility, wich allowed aproximating productive indexes for predictions proposed in this work. 


\section{INTRODUÇÃO}

O bem-estar dos animais, juntamente com as questões ambientais e a segurança dos alimentos, vem sendo considerado, entre os três maiores desafios da agropecuária mundial. A convicção dos consumidores de que os animais utilizados para a produção de alimentos devem ser bem tratados. Ganha cada vez mais importância, principalmente junto a União Européia (UE) e frente aos países que colocam animais vivos ou produtos de origem animal nos estados membros.

Assuntos como rastreabilidade da produção, certificação de origem e zootecnia de precisão estão sendo discutidos em todas as cadeias produtivas, com o objetivo de maximizar os sistemas de produção existentes, promovendo redução de perdas e, conseqüentemente, garantindo melhorias do produto final, visando ao incremento nas exportações.

Nosso país vem atravessando, nos últimos anos, uma ótima fase com relação às exportações de proteína animal. Neste contexto, a carne suína merece um destaque especial, pois, apesar de algumas barreiras colocadas recentemente ao setor de exportação, o Brasil se mostra na vanguarda e ocupa hoje um importante posto no ranking dos países exportadores.

A produção mundial de carne suína, em 2004 , cresceu à taxa de $0,9 \%$ sobre o ano anterior, conservando a posição de proteína animal mais consumida no planeta. Segundo dados publicados pelo USDA - Departamento de Agricultura dos Estados Unidos foram produzidos 88.303 milhões de toneladas. O Brasil, ainda em fase de crescimento, foi responsável por 3,0 \% da produção mundial.

As exportações brasileiras de carne suína no ano de 2004 somaram 459,1 mil toneladas verificando-se uma redução em torno de 7\% em relação ao mesmo período 
do ano anterior, de 493,9 mil toneladas. É importante ressaltar que o Brasil se encontra na terceira posição entre os maiores exportadores mundiais de carne suína (ANUALPEC, 2004).

Frente as atuais demandas, não se pode mais considerar sistema de produção animal, cadeia produtiva, padrões comportamentais, sem considerar esses novos conceitos de bem-estar na produção. Diante disso, a utilização de novas tecnologias e ferramentas como a informática (softwares), microeletrônica, técnicas de modelagem, sistemas inteligentes, monitoramento por imagens, sensores e atuadores, pode melhorar o trabalho científico-tecnológico, favorecendo a acurácia das pesquisas e o desenvolvimento de sistemas especialistas para tomada de decisão.

O ambiente do sistema de criação intensivo possui influência direta na condição de conforto e bem-estar animal, promovendo dificuldade na manutenção do balanço térmico no interior das instalações, na qualidade química do ar e na expressão de seus comportamentos naturais, afetando o desempenho produtivo e reprodutivo dos suínos.

Produtores e consumidores estão cada vez mais sensibilizados para os efeitos que as técnicas de reprodução e criação podem ter para os animais, a sua saúde e bem-estar e, o que não é menos importante, o impacto ambiental causado pelo sistema de produção. Na busca de se obter um produto de qualidade, diversas vantagens podem ser observadas para o processo produtivo. Dessa forma, a busca pela adequação às diretrizes expostas, criou-se no estado de São Paulo o selo suíno paulista de certificação, sendo interessante não apenas sob o ponto de vista de marketing da carne, mas também da saúde pública, por se tratar da garantia do fornecimento de uma carne de melhor qualidade. É também uma medida importante para a melhoria das condições sanitárias e zootécnicas do plantel de suínos da propriedade e da suinocultura estadual (Sarubbi, 2005).

Os mais diversos países apresentam atitudes culturais e éticas diferentes para com os animais e aplicam práticas zootécnicas distintas. O impacto de normas exigentes de bem-estar dos animais na competitividade da sua agropecuária também pode ser muito diferente. 
Por conseguinte, quando estão previstas num país normas de bem-estar mais exigentes do que as que são aplicadas por outros parceiros comerciais, o fato poderá ter várias conseqüências. Os consumidores podem não dispor de informação coerente sobre as normas vigentes com as quais são produzidos os produtos importados, e os produtores nacionais podem ficar em desvantagem econômica.

A legislação da UE dirigida ao bem-estar dos animais aumentou consideravelmente nos últimos anos, tendência que deverá acelerar, especialmente diante do Tratado de Amsterdã e o estabelecimento relativo às normas mínimas de proteção aos suínos (Diretiva 91/630/CEE) que consagra as ambições de todas as instituições da UE de fazer o máximo para melhorar os padrões de bem-estar, sendo cada vez mais reconhecido o fato de elevados padrões de bem-estar terem impacto direto e indireto na segurança dos alimentos e na qualidade final dos produtos, fazendo-se necessária a adaptação dos atuais modelos de produção animal.

As normas da UE referentes às matrizes gestantes, preconiza alojamento coletivo, em estabulação livre, para permitir um adequado contato social. Proibindo instalações onde os animais sejam mantidos isolados, com utilização de celas, coleiras ou cintas. Nesta fase, o alojamento individual é permitido antes da cobrição, inseminação, ou para tratamento, definindo-se um período de adaptação aos sistemas de contenção existentes até $1^{\circ}$ de janeiro de 2006 .

Contudo, este processo implica em aumento nos custos dos produtores, pelo fato de qualquer requisito que implique investimentos e mudança dos sistemas produtivos, apresentam impacto nos custos de produção. Não é, todavia, fácil quantificar, em termos gerais, tal impacto. Numa comunicação sobre o bem-estar dos suínos, a comissão estimou os custos inerentes à supressão das celas individuais para porcas entre 0,006 e $0,02 €$ por quilograma de carcaça de suíno, considerando-se o período de transição.

Cumpridas as legislações estabelecidas pela UE e de seus respectivos períodos de vigência, e para que os consumidores possam certificar-se de que compram carne suína produzida de acordo com estas normas exigentes em matéria de bem-estar, convém introduzir, com a maior brevidade possível, um programa de rastreabilidade que assinale esse fato, beneficiando os produtores de países parceiros que atendem as normas mais 
exigentes em matéria de bem-estar dos animais e que estabeleçam relação comercial com algum membro da UE.

Desta forma, é necessário lembrar que qualquer proposta relativa ao bem-estar dos suínos deve basear-se em resultados de estudos científicos realizados com animais de produção, evitando possíveis distorções do mercado comum europeu frente a importações de carne suína de países exportadores.

Baseando-se nisso, o objetivo geral desta pesquisa consiste na avaliação de diferentes sistemas de alojamento para matrizes gestantes, visando caracterizar aspectos quantitativos e qualitativos do ambiente e as variáveis que influenciam o sistema de produção, determinando as condições favoráveis ao melhor desempenho animal, baseada nas respostas ao ambiente de criação.

Por outro lado, os objetivos específicos são:

- analisar a inter-relação animal e ambiente, sob o ponto de vista bioclimático, verificando-se as influências dos elementos meteorológicos e os aspectos relacionados à qualidade química do ar, e seus reflexos no conforto animal, na fase de gestação, em uma produção industrial de suínos;

- verificar a eficiência de diferentes sistemas de produção, no confinamento de matrizes em baias individuais de gestação e coletivas, visando ao estudo do comportamento animal, e seus reflexos nos parâmetros fisiológicos e índices zootécnicos;

- avaliar novas tecnologias para o estudo, análise e determinação de padrões de conforto e bem-estar animal aplicados a matrizes gestantes, por meio de sistemas inteligentes, lógica fuzzy e predição de índices zootécnicos usando redes neurais artificiais (RNAs). 


\section{REVISÃO DE LITERATURA}

\subsection{Aspectos relacionados à bioclimatologia animal}

O conceito de bioclimatologia é amplo, uma vez que inclui todas as condições que afetam o desenvolvimento dos animais, envolvendo aspectos fisiológicos e ambientais (Curtis \& Backstrom, 1992).

Baldwin (1979) dividiu os componentes ambientais em físicos (temperatura, umidade, ventilação, tipologia das instalações), sociais (hierarquia, tamanho e composição do grupo, presença ou ausência de animais estranhos) e introduziu o item manejo (dieta, formas de arraçoamento, desmame). O ambiente físico, por abranger os elementos meteorológicos que afetam os mecanismos de transferência de calor, a regulação e o balanço térmico entre o animal e o meio, exerce forte influência sobre o desempenho e a saúde dos animais (ASHRAE, 1983).

O suíno é considerado como um agente modificador do meio em que vive, seja através da geração de calor, vapor d'água, fezes, urina ou como foco de desenvolvimento de patógenos. Nestas condições, o verdadeiro ambiente passa a ser aquele reinante no interior da edificação ou aquele cujo ar os animais respiram (Benedi, 1986).

A primeira condição de conforto térmico animal dentro de uma instalação é que o balanço térmico seja nulo, ou seja, o calor produzido pelo organismo animal, somado ao calor ganho do ambiente, seja igual ao calor perdido. A termólise e a termogênese que ocorrem durante a termorregulação envolvem as trocas de calor sensível, condução, radiação, convecção e as trocas de calor latente pela evaporação e condensação, sendo que o animal aciona estes mecanismos regulatórios de acordo com a temperatura ambiente, comparativamente a sua zona de termoneutralidade (Nääs, 2000). 
Em geral, as trocas de calor entre o animal e o ambiente em instalações, onde a temperatura é inferior a $25{ }^{\circ} \mathrm{C}$, predominam os processos não evaporativos, em que $15 \%$ das perdas de calor se dão por condução, $40 \%$ por radiação, $35 \%$ por convecção e somente $10 \%$ por evaporação. No entanto, em locais onde a temperatura ambiente se encontra acima de $30{ }^{\circ} \mathrm{C}$ predominam as perdas por processos evaporativos, por evaporação de água na superfície da pele, proveniente de sistemas de climatização e pela respiração (Sorensen, 1964; Sainbury, 1972; Esmay, 1982).

\subsubsection{Variáveis meteorológicas}

\subsubsection{Temperatura}

$\mathrm{Na}$ espécie suína, como em outros animais, existe um gradiente de temperatura no sangue, tecidos e no reto, em que as temperaturas tornam-se mais baixas no sentido do exterior. Ainda, em locais mais profundos do corpo, existem diferenças de temperatura, com uma tendência de elevação em tecidos ou órgãos mais ativos metabolicamente. Por exemplo: a temperatura no fígado pode estar 1 ou $2{ }^{\circ} \mathrm{C}$ acima da retal (Anderson, 1988) e a do cérebro é, geralmente, um pouco mais alta do que a do sangue na artéria carótida. Desta forma, estas regiões sofrem mais resfriamento do que aquecimento pelo sangue arterial.

A temperatura das partes periféricas do corpo, assim como dos membros, pode ser até $10^{\circ} \mathrm{C}$ mais baixa do que a temperatura central (Anderson, 1988).

A região que apresenta temperatura mais próxima da Temperatura Corporal Profunda (TCP) é o reto. Embora a Temperatura Retal (TR) não represente uma média da TCP, o equilíbrio na TR ocorre mais lentamente do que em outros pontos internos, tornando-se um índice de equilíbrio dinâmico verdadeiro. Deve-se considerar ainda a praticidade de se proceder à aferição. No suíno, considera-se como temperatura média o valor de $39,2{ }^{\circ} \mathrm{C}$, com variações entre 38,7 e $39,8^{\circ} \mathrm{C}$ (Anderson, 1988).

Com suínos expostos a temperaturas ambientais de $18,24,28$ e $32{ }^{\circ} \mathrm{C}$, umidade relativa do ar em torno de $40 \%$ e com velocidade do vento de $0,15 \mathrm{~m} . \mathrm{s}^{-1}$ durante um período de 8 horas, verificou-se um aumento significativo na temperatura retal, quando a 
temperatura atingiu ou ultrapassou os $30{ }^{\circ} \mathrm{C}$, a taxa respiratória apresentou grandes diferenças a partir de $24{ }^{\circ} \mathrm{C}$, caracterizando-se como um indicativo de alerta à condição de estresse térmico e um parâmetro suporte na tomada de decisão (Yan et al., 2000; Brown-Brandl et al., 2001).

A temperatura ambiente considerada ótima para a matriz varia entre 7 e $23{ }^{\circ} \mathrm{C}$ (Noblet et al., 1989). Nas matrizes, as altas temperaturas no interior das instalações influenciam negativamente a eficiência reprodutiva. Em locais onde as temperaturas no verão foram superiores a $24{ }^{\circ} \mathrm{C}$, verificou-se diminuição da fertilidade das fêmeas suínas, alta porcentagem de retorno ao cio (Love et al., 1995; Wentz et al., 1997; Bortolozzo et al., 1997; Peltoniemi et al., 1999), principalmente nas fêmeas primíparas (Vieira \& Vieira, 1987), atraso da maturidade sexual (Perez y Perez \& Guitierrez, 1987; Flores et al., 1989) e maior mobilização de gordura corporal durante a lactação (Barb et al., 1991). Ao contrário, em regiões onde os dias quentes não ultrapassaram a temperatura de $24{ }^{\circ} \mathrm{C}$, não foram observados efeitos significativos sobre a fertilidade e taxa de concepção das fêmeas (Love et al., 1993).

\subsubsection{Umidade do ar}

O limite de tolerância do suíno à umidade depende da temperatura, da idade e das características físicas e metabólicas do animal (Heitman \& Hughes, 1951; Rousseau et al., 1989).

A importância da umidade do ar sobre o metabolismo energético do suíno, em condições termoneutras, não está bem esclarecida, no entanto verificou-se que altos valores diminuem a habilidade para dissipação do calor corporal em altas temperaturas, como resultado da dificuldade para evaporação da água em nível pulmonar e pele, processo que demanda energia e, conseqüentemente, a eliminação de calor e redução da temperatura corporal (Roller et al., 1967; Fonda, 1978).

O suíno apresenta dificuldade para dissipar calor em ambiente de alta temperatura e umidade, pois o excesso de umidade restringe as perdas evaporativas pela respiração e contribui para diminuir o apetite. A elevação da umidade relativa de 45 para $90 \%$ a uma temperatura de $21{ }^{\circ} \mathrm{C}$ é responsável pela redução em até $8 \%$ das perdas de calor, sendo 
que o ideal para suínos em condições satisfatórias de temperatura é de uma umidade relativa entre 60 e $80 \%$ (Nienaber et al., 1987).

O maior impacto da umidade para os suínos resulta de sua influência sobre a viabilidade dos agentes infecciosos, garantindo a manutenção de microrganismos patogênicos nas partículas aerolizadas, sugerindo-se valores ótimos de 50 a 75\% para leitões e 55 a $75 \%$ para as matrizes (Veit \& Troutt, 1982).

\subsubsection{Ventilação}

A importância da ventilação resulta da intensidade com que afeta as perdas de calor, dissipando o calor de radiação, condução e convecção, sendo de grande importância para o conforto térmico e para higiene em geral. A renovação do ar permite não só a dissipação de calor, como também a desconcentração de vapores, fumaça, poeira e gases poluentes.

A ventilação também se torna importante na remoção do vapor d'água proveniente da respiração dos animais e fermentação dos dejetos, além de processos de lavagens das baias.

A qualidade do ar no interior das instalações é influenciada pela ventilação podendo contribuir de forma positiva, se bem planejada. Ventilação insuficiente é responsável por aumentar os níveis de poluentes aéreos como a amônia $\left(\mathrm{NH}_{3}\right)$ e o dióxido de carbono $\left(\mathrm{CO}_{2}\right)$. Estudos sobre a relação entre o conforto térmico e concentração de gases (Takai et al., 1998; Koerkamp et al., 1998) evidenciaram uma relação direta entre o ambiente externo e a formação de gases dentro da instalação, sendo também uma função direta da ventilação e da temperatura dentro e fora da instalação, geometria da construção, número de animais alojados, manejo entre outros.

A eficiência da ventilação pode ser avaliada pela velocidade do ar incidente sobre os animais, pelo número de renovações por hora e pela concentração de gases (Gordon, 1962).

De maneira geral, a recomendação para velocidade incidente diretamente sobre os animais, é de 0,1 a $0,2 \mathrm{~m} . \mathrm{s}^{-1}$ para leitões lactentes e de 0,1 a $0,3 \mathrm{~m} \cdot \mathrm{s}^{-1}$ para matrizes em 
lactação, com um fluxo de ventilação adequado da ordem de $0,03 \mathrm{~m}^{3} \cdot \mathrm{s}^{-1}$. animal $^{-1}$ (Dividich \& Rinaldo, 1989; Moura, 1999).

\subsubsection{Variáveis ambientais}

\subsubsection{Concentração de gases}

A insalubridade no ambiente de trabalho é pouco considerada no meio rural. Toma ainda maiores proporções na suinocultura e avicultura intensiva, atividades em que o animal se encontra em um ambiente com altos níveis de ruído, gases (amônia, gás carbônico, gás sulfídrico) e poeiras que, muitas vezes, ultrapassam limites compatíveis com o bem-estar e a saúde dos animais.

Os gases mais importantes nas instalações de suínos são a amônia $\left(\mathrm{NH}_{3}\right)$, o gás carbônico $\left(\mathrm{CO}_{2}\right)$ e o gás sulfídrico $\left(\mathrm{H}_{2} \mathrm{~S}\right)$ (Bruce, 1981; Perdomo et al., 2001). A produção de metano $\left(\mathrm{CH}_{4}\right)$ é pequena na criação de suínos, representando menos de $1 \%$ da energia consumida e, comparada à produção de ruminantes, resultam valores insignificantes, sendo levemente superiores a $1 \mathrm{~kg}$ de $\mathrm{CH}_{4}$ por cabeça/ano. $\mathrm{O} \mathrm{CH}_{4}$ possui efeito narcótico em grandes quantidades e, por esta razão, não é problema na suinocultura. $\mathrm{O}$ aumento destes gases diminui a concentração de oxigênio a quantidades muito baixas (Verstegen et al., 1994). A degradação biológica dos resíduos produz gases tóxicos, cuja exposição constante a níveis elevados pode reduzir o desempenho zootécnico dos suínos e incapacitar precocemente os tratadores para o trabalho (Perdomo et al, 2001). A inalação de grandes concentrações de gases nocivos, emitidos pelo esterco animal, tem provocado a morte de pessoas e animais (Nader et al., 2002).

Segundo a Commission Internationale du Génie Rural (CIGR, 1994), os gases são provenientes da respiração dos animais e de outras fontes, como pela decomposição microbiana de urina e fezes, que é afetada pela temperatura, $\mathrm{pH}$ e umidade da massa de excrementos. As recomendações pela CIGR (1994) para concentração de amônia $\left(\mathrm{NH}_{3}\right)$, sulfeto de hidrogênio $\left(\mathrm{H}_{2} \mathrm{~S}\right)$, monóxido de carbono $(\mathrm{CO})$ e dióxido de carbono $\left(\mathrm{CO}_{2}\right)$ aos animais são apresentados na Tabela 1. 
Tabela 1. Recomendação máxima de amônia $\left(\mathrm{NH}_{3}\right)$, sulfeto de hidrogênio $\left(\mathrm{H}_{2} \mathrm{~S}\right)$, monóxido de carbono $(\mathrm{CO})$ e dióxido de carbono $\left(\mathrm{CO}_{2}\right)$ em instalações para suínos

\begin{tabular}{lcc}
\hline Gases & $\begin{array}{c}\text { Concentração máxima } \\
(\text { ppm })\end{array}$ & Observação \\
\hline $\mathrm{NH}_{3}$ & 20 & Zona dos animais \\
$\mathrm{H}_{2} \mathrm{~S}$ & 0,5 & Zona dos animais \\
$\mathrm{CO}$ & 10 & Ambiente \\
$\mathrm{CO}_{2}$ & 3000 & - \\
\hline
\end{tabular}

Fonte: CIGR, (1994); SAMPAIO, (2004).

A amônia é um poluente resultante da decomposição microbiana (aeróbia e anaeróbia) de compostos nitrogenados (fezes e urina) e emitida na sua forma volátil para o ar, sendo que a uréia existente na urina dos suínos é a principal fonte hidrossolúvel, podendo portanto, ser absorvida tanto pelas partículas de poeira e pela cama, como pelas membranas das mucosas. É tóxica para as células animais, e os sintomas conhecidos de envenenamento por amônia incluem conjuntivite, tosse, espirro e dispnéia. A exposição à amônia causa irritação às membranas mucosas nos olhos e no sistema respiratório; é capaz de aumentar a susceptibilidade a doenças respiratórias; e pode afetar o consumo alimentar, a eficiência da conversão alimentar e a taxa de crescimento (Kristensen et al., 2001).

A emissão da amônia no interior das edificações também é influenciada pelo aumento da temperatura ambiente. De acordo com o modelo desenvolvido por Aarnink \& Elzing (1998), a emissão deste gás tem um acréscimo de 6 a $7 \%$ para cada $1{ }^{\circ} \mathrm{C}$ de aumento na temperatura.

Outro ponto a considerar é a sinergia entre amônia $\left(\mathrm{NH}_{3}\right)$, poeira e microorganismos, com a potencialização dos efeitos negativos sobre a saúde animal. $\mathrm{O}$ gás amônia e as partículas de poeira suspensas no ar criam uma carga adicional sobre o sistema respiratório e facilitam a entrada e a multiplicação de microorganismos infecciosos no trato respiratório (Pickrell, 1991; CIGR, 1994; Gustafsson, 1997). Com base nesses estudos, Donham (1999) recomenda, como segurança, uma concentração máxima de 7 ppm de amônia em instalações para suínos. 
$\mathrm{O}$ sulfeto de hidrogênio $\left(\mathrm{H}_{2} \mathrm{~S}\right)$ é considerado um dos gases mais perigosos à saúde dos animais, gerado a partir da decomposição anaeróbia dos dejetos, quando estes são estocado por algum tempo, sendo que sua presença nas edificações para animais normalmente é em concentração inferior a de outros gases poluentes, como $\mathrm{NH}_{3}$ e o $\mathrm{CO}_{2}$ (CIGR, 1994).

$\mathrm{O}_{2} \mathrm{~S}$ é detectado na concentração de 0,01 ppm ou mais, e entre 50-200 ppm pode acarretar sintomas, tais como: perda de apetite, fotofobia, vômito e diarréia nos animais. Recomenda-se que os níveis de $\mathrm{H}_{2} \mathrm{~S}$ nas edificações não ultrapassem os 5 ppm (Larry et al., 1994; Perdomo et al., 2001).

A respiração de ar com contaminantes desenvolve lesões nos pulmões associadas com acúmulo de fluido e baixa oxigenação sangüínea, tornando os animais mais susceptíveis a infecções (Appleby et al., 1992).

O gás carbônico é um gás presente na atmosfera, sem cheiro, e quando a concentração é de 50.000 ppm, causa nos animais um aumento no ritmo respiratório e respirações mais profundas. Concentração de 400.000 ppm pode ocasionar ansiedade, seguida de vertigem, coma e morte. (Nader et al., 2002).

Um animal de $50 \mathrm{~kg}$ produz, aproximadamente, $450 \mathrm{~kg}$ de $\mathrm{CO}_{2} /$ ano. (Verstegen et al, 1995). É o principal produto metabólico produzido por microorganismos heterotróficos presentes na cama. Em criações sobre cama, a atividade destes microorganismos é influenciada pela temperatura, $\mathrm{pH}$ e quantidade de oxigênio na cama (Deaton, 1995).

$\mathrm{O} \mathrm{CO}_{2}$ é mais denso do que o ar, inodoro e asfixiante. A concentração máxima admissível na edificação é de 3.000 ppm, sendo que valores superiores a 20.000 ppm provocam aumento dos batimentos cardíacos, sonolência e dor de cabeça. Permanece nas camadas mais baixas das edificações e das estruturas de armazenagem, deslocando gradualmente os gases mais leves. Perdomo et al. (2001) relatam que, em 1995, encontraram concentrações de $0,003 \%$ em edifícios climatizados naturalmente e de 0,0038\% naqueles climatizados artificialmente, muito abaixo daqueles referidos como tóxicos. 
O monóxido de carbono ( $\mathrm{CO}$ ) é um poluente local, resultante do processo de combustão incompleta dos combustíveis usados no aquecimento das instalações, gerando insuficiência de oxigênio $\left(\mathrm{O}_{2}\right)$ no ar. É considerado um asfixiante químico, que tem maior afinidade com a hemoglobina do que o $\mathrm{O}_{2}$, impedindo o transporte deste, podendo causar lesões ao sistema nervoso, cefaléias e a paralisação de membros.

Segundo a CIGR (1994), são reportados casos em que o CO causou morte em suínos adultos na concentração de 2000 ppm. Barker et al. (2002) descreveram que suínos expostos entre 200-250 ppm de CO ficaram menos ativos e, acima de 1500 ppm, são ocasionados abortos, natimortos e redução no desempenho dos leitões.

É necessário, portanto, um controle da qualidade do ar, nas instalações de abrigos para suínos que, provavelmente, melhorarão os níveis de produtividade, expondo os animais a menores riscos de saúde. Quanto à concentração de gases, principalmente quando se trata da amônia, é necessário uma mensuração mais freqüente.

Algumas pesquisas visam viabilizar a utilização de equipamentos de mensuração de gases minimizando os custos de aquisição e manutenção dos equipamentos (Xin et al., 2002). Havendo um controle da qualidade de ar, através de manejos de ventilação e nebulização, é possível manter o ambiente dentro dos níveis aceitáveis apontados pela legislação brasileira (Alencar et al., 2002).

No Brasil, as pesquisas com qualidade do ar na suinocultura são realizadas por vários pesquisadores, possibilitando o estabelecimento de regras práticas para a manutenção de níveis adequados para os gases considerados tóxicos, no sentido de se conhecer e controlar tais variáveis (Sampaio, 2004; Nääs, 2002; Nader et al., 2002; Perdomo, 2001).

\subsubsection{Bem-estar animal}

O bem-estar animal pode ser considerado uma demanda para que um sistema seja defensável eticamente e aceitável socialmente e, segundo Warriss (2000), as pessoas desejam comer carne com "qualidade ética", isto é, carne oriunda de animais que foram criados, tratados e abatidos em sistemas que promovam o seu bem-estar, e que sejam sustentáveis e ambientalmente corretos. 
É por isso que a UE entende que há uma necessidade evidente de debater a questão do bem-estar dos animais no contexto da Organização Mundial de Comércio (OMC). As questões são reais, para produtores e consumidores, e a OMC, na sua qualidade de principal organização comercial internacional, deve estar preparada para abordar essas questões. Atendendo à inter-relação existente entre as medidas de bem-estar dos animais e o comércio internacional de produtos agrícolas e alimentares de origem animal, a UE considera que esta questão deve ser abordada no contexto das negociações sobre agropecuária, visando ao estabelecimento de um conjunto de normas que caracterize as exigências sobre o bem-estar na exploração de animais domésticos, caracterizando-se efetivamente as barreiras técnicas à comercialização.

$\mathrm{Na}$ União Européia, uma questão polêmica que se coloca com freqüência cada vez maior na suinocultura são as novas regulamentações sobre o bem-estar, podendo apresentar impacto sobre a suinocultura brasileira à medida que podem afetar as importações européias de carne suína.

A proposta da Diretiva do Conselho $\operatorname{COM}(2001) 20$ - C5-0039/2001 2001/0021(CNS) que altera a Diretiva 91/630/CE, com base nas disposições do artigo $6^{\circ}$, tem os seguintes objetivos:

- proibir a utilização de celas individuais para as porcas e marrãs prenhes, bem como a utilização de amarras;

- aumentar a área livre destinada às porcas e marrãs;

- permitir que as porcas e marrãs tenham acesso a materiais para fuçar;

- elevar o nível de formação e a competência dos suinocultores e do pessoal responsável pelos animais em relação às questões relacionadas com a proteção;

- solicitar novos pareceres científicos sobre certas questões do domínio da suinocultura.

As normas referentes às matrizes dependem da sua fase no ciclo reprodutivo, pode-se distinguir porcas em crescimento, secas e em gestação e porcas em preparação para o parto ou em fase de parto e cria.

O alojamento das matrizes em crescimento, secas ou em gestação, deve ser feito em grupo, em estabulação livre, para permitir um adequado contato social. A partir de 1 
de janeiro de 1996 foram proibidos, através da diretiva européia, a construção ou reformas de instalações em que os animais sejam mantidos em confinamento individual, através de celas individuais, coleiras ou cintas. O alojamento individual nestas fases é apenas permitido antes da cobrição, inseminação, ou para tratamento. Foi definido um período de transição para as instalações já existentes, até 1 de janeiro de 2006.

As matrizes em preparação para o parto, ou durante a fase de parto e cria, devem ser alojadas em maternidades que satisfaçam as necessidades da mãe e dos leitões. A área de repouso da porca deve ser limpa, confortável e bem drenada.

Segundo Fraser (1999), a maioria das tentativas dos cientistas de conceituar o bem-estar animal resume-se em três questões principais:

- os animais devem sentir-se bem, não serem submetidos ao medo, à dor ou estados desagradáveis de forma intensa ou prolongada;

- os animais devem funcionar bem, no sentido de saúde, crescimento e funcionamento comportamental e fisiológico normal;

- os animais devem levar vida natural através do desenvolvimento e do uso de suas adaptações naturais.

Uma definição de bem-estar bastante utilizada atualmente foi estabelecida pela FAWC (Farm Animal Welfare Council) citada por Chevillon (2000), na Inglaterra, mediante o reconhecimento das cinco liberdades inerentes aos animais:

1. a liberdade fisiológica (ausência de fome e de sede),

2. a liberdade ambiental (edificações adaptadas),

3. a liberdade sanitária (ausência de doenças e de fraturas),

4. a liberdade comportamental (possibilidade de exprimir comportamentos normais),

5. a liberdade psicológica (ausência de medo e de ansiedade).

O bem-estar dos animais poderá ser abordado de várias formas, que não se excluem mutuamente, sendo possível atingir um resultado que abranja a combinação de várias ações, tais como:

- estabelecimento de acordos multilaterais relativos à proteção do bem-estar dos animais. Esta abordagem será facilitada por uma definição jurídica mais clara da relação 
entre as regras da OMC e as medidas comerciais tomadas nos termos das disposições de acordos multilaterais no domínio do bem-estar dos animais;

- uma rotulagem adequada, obrigatória ou facultativa, possibilitando dar resposta ao desejo dos consumidores, que querem fazer uma escolha informada no que se refere aos produtos alimentares, de origem nacional ou importados, inclusive no que diz respeito às condições de produção, por exemplo, produtos produzidos em conformidade com determinadas normas de bem-estar dos animais;

- normas muito exigentes de bem-estar dos animais podem contribuir para elevar os custos para os produtores para além do possível acréscimo do valor de mercado desses produtos. A liberalização do comércio pode agravar este efeito, criando condições de concorrência desiguais, ou mesmo obrigando a uma redução do rigor das normas de bem-estar dos animais dos países exportadores, o que, por seu turno, poderá suscitar a oposição à liberalização comercial e a OMC. Portanto, será necessário ter em consideração a possível legitimidade de prever qualquer tipo de compensação desses custos suplementares, quando possa ser claramente demonstrado que derivam diretamente das normas mais exigentes em causa. Para que essa compensação seja aceitável, não deverá ter efeitos no comércio ou na produção ou, se os tiver, deverão ser mínimos.

O bem-estar pode ser medido por métodos científicos e deve ser independente de quaisquer considerações éticas, culturais ou religiosas. São usados vários indicadores para aferir o bem-estar de um animal, como o dano físico, a dor, o medo, o comportamento, a redução de defesas do sistema imunológico e a incidência de doenças (Meneses, 1999).

Na prática da etologia, o bem-estar é avaliado por meio de indicadores fisiológicos e comportamentais. As medidas fisiológicas associadas ao estresse têm sido usadas com base em que, se o estresse aumenta, o bem-estar diminui. Já os indicadores comportamentais são baseados especialmente na ocorrência de comportamentos anormais, e daqueles que se afastam do comportamento no ambiente natural.

O estresse é um termo geral que implica uma ameaça à qual o corpo precisa se ajustar (Von Borell, 1995). Segundo Fraser et al. (1975), diz-se que um animal está em 
estado de estresse, se é necessário que se façam ajustes anormais ou extremos em sua fisiologia ou comportamento para ajustar-se a aspectos adversos do seu ambiente e manejo. Esta adaptação envolve uma série de respostas neuroendócrinas, fisiológicas e comportamentais que funcionam para tentar manter a homeostase, o equilíbrio de suas funções, e na integração destes sistemas (Barnett et al., 1992; Von Borell, 1995).

Weary et al. (1999) estudaram o efeito da separação de leitões da mãe e do desmame e dieta em diferentes idades, e concluíram que o estresse produzido pela separação e frustração da motivação de mamar são problemas comportamentais significantes, quando os leitões são desmamados com menos de quatro semanas. A dieta especializada não solucionou o estresse do desmame nem implicou melhor ganho de peso.

Os suínos têm um repertório comportamental complexo, principalmente em relação às atividades sociais, além de uma grande capacidade de aprendizado. Assim, podem surgir problemas de bem-estar, se não conseguirem controlar seu ambiente, ter seu comportamento natural frustrado ou forem sujeitos a situações imprevisíveis. Stolba \& Wood-Gush (1989) observaram suínos em ambiente seminatural e verificaram 103 elementos comportamentais diferentes. Além disso, embora a domesticação forneça alimento e outros cuidados aos animais, os suínos domésticos ainda mantêm comportamentos observados em ambientes naturais, como a construção de ninhos antes do parto pelas matrizes (Gustafsson et al., 1999).

As formas de criação intensiva, ou industriais, em que o animal permanece durante toda a sua vida em instalações fechadas, muitas vezes isolado dos outros suínos e em espaço reduzido, vieram alterar drasticamente as suas formas normais de comportamento, criando diversas situações de estresse. Como conseqüência, começaram a aparecer grupos de pessoas preocupadas com o bem-estar dos animais e nomeadamente com as soluções de alojamento e manejo adequados, muitas vezes sem qualquer respaldo técnico-científico.

Dessa forma, a avaliação do bem-estar animal na exploração agropecuária pode envolver aspectos ligados às instalações, ao manejo e ao ambiente, tais como a distribuição de água e de comida, existência de camas, possibilidade de movimento, 
descanso, contato entre animais e reprodução, temperatura, ventilação, luz, espaço disponível ou tipo de pavimento.

\subsection{Sistemas de produção}

Atualmente, a criação de suínos é feita sob dois regimes. O regime intensivo, em que os animais são criados em instalações fechadas, de ambiente controlado, com grandes restrições de espaço e em pavimentos artificiais, e as explorações extensivas, em que os animais são criados ao ar livre, em grandes áreas, com grande liberdade de movimentos, que poderão dispor de abrigos simples. Na primeira situação, os animais são criados em condições artificiais, com variadas restrições, sem contato com a natureza, sendo freqüentes as ocorrências de estresse. No segundo sistema de produção, passam a vida em contato com o solo, podendo assim fuçar, explorar e desenvolver outros comportamentos que lhe são próprios (Meneses, 1999).

Com o crescimento da população mundial, a partir do início do século $\mathrm{XX}$, o consumo de proteína animal aumentou consideravelmente. A partir da década de 60 , as antigas criações extensivas e de fundo de quintal passaram a se intensificar, caracterizando-se pelo alojamento de um grande número de animais em um espaço bem mais reduzido do que até então. Isto tornou possível o grande aumento na produção de alimentos de origem animal para consumo humano.

O confinamento foi o caminho para reduzir o trabalho e a perda energética dos animais, ganhar espaço, e melhorar o controle ambiental. Agravam-se, então, problemas de comportamento e bem-estar animal. Um animal que não esteja em condição de bemestar, não irá desenvolver seu potencial produtivo na sua magnitude, mesmo que condições sanitárias e nutricionais estejam aparentemente satisfeitas. Em condições de limitação de espaço, alta densidade animal, presença de microorganismos, condições de temperatura e luminosidade inadequadas, ruídos, dentre outros, o animal ficará impossibilitado de desenvolver seu sistema natural de comportamento (Machado Filho \& Hötzel, 2000).

No entanto, as condições da criação intensiva exigiram as adaptações fisiológicas e comportamentais dos animais, que devem ser estudadas para avaliar os sistemas de 
manejo. Muitos dos atuais problemas na criação de animais não podem ser solucionados por pesquisas em nutrição, fisiologia ou controle de doenças, requerem investigações do comportamento animal para que se possa ter progresso. Esta idéia ainda é sustentada em vários setores da produção animal, especialmente nos animais criados de forma intensiva, como suínos e aves.

As matrizes confinadas podem ter dificuldade de termorregulação, não podem interagir com outros animais e afastar-se de pessoas e estímulos potencialmente ameaçadores. Uma das respostas a esta falta de controle do ambiente é o comportamento estereotípico. A estereotipia é uma seqüência repetida e invariável de movimentos sem um objetivo óbvio (Fraser \& Broom, 1990). Isto é observado com freqüência em baias individuais de gestação, onde se verificam comportamentos como o ato de morder as barras da cela, repetitiva checagem do cocho mesmo sem alimento, pressionar a chupeta do bebedouro obsessivamente, explorar o ambiente (fuçar), enrolar a língua, esticar o pescoço e observar o ambiente a sua volta, são alguns exemplos de estereotipias, que podem ser observados em até $80 \%$ das horas de análise comportamental durante a luz do dia (Stolba et al., 1983; Cronin \& Wiepkema, 1984). Estudos demonstram que a função destas estereotipias é acalmar as matrizes (Schouten et al., 2000). Por exemplo, VieuilleThomas et al. (1995) verificaram uma maior proporção de matrizes confinadas individualmente com estereotipias do que nas alojadas em grupo. Matrizes alimentadas com dieta rica em fibra apresentaram estereotipias menos evidentes do que as alimentadas com concentrado (Whittaker et al., 1999).

A alimentação controlada de matrizes reprodutoras em sistemas de produção industrial de suínos é uma das principais causas de bem-estar reduzido. A adoção desta prática de manejo se faz necessário na prevenção do excesso de ganho de peso e no comprometimento do desempenho reprodutivo dos animais. Embora sua alimentação contemple as necessidades diárias de nutrientes e energia para manutenção e reprodução, os animais não se sentem saciados durante pelo menos parte do dia. Logo após o arraçoamento, a motivação para procura de mais alimento é alta (Lawrence et al., 1988).

Freqüentemente os sistemas de alojamento não possibilitam a expressão do hábito de forragear, evidenciando-se comportamentos anormais como a mastigação na ausência 
de alimento e o ato de morder barras de contenção. Vários estudos mostraram que a ocorrência de comportamento estereotípico pode ser reduzida em confinamento que disponha de cama e/ou substrato que permita que o animal o explore, potencializando o efeito da satisfação nutricional proporcionado por uma dieta de alta complexidade (Fraser, 1975; Spoolder et al., 1995; Whittaker et al., 1998; Whittaker et al., 1999; De Leeuw et al., 2003).

A exigência mínima de espaço por animal é difícil de ser estabelecida, uma vez que ela varia de acordo com os fatores ambientais e de manejo. $\mathrm{O}$ efeito do espaço resulta, indiretamente, do número de animais por unidade de área, possibilitando ao animal liberdade de movimento, caracterizando-se como um dos principais itens para avaliação do bem-estar dos animais. Sua escolha poderia ser feita por uma análise econômica que incorporasse as alternativas de custos e que atendesse às expectativas de conforto térmico, social e de manejo (Webster, 1993).

Quanto ao tamanho do grupo, para matrizes gestantes alojadas em baias coletivas, deveria ser respeitado o menor número possível, o que estaria em torno de quatro a nove animais, com uma área sugerida acima de $1,5 \mathrm{~m}^{2}$ por fêmea (Hemsworth et al., 1986; Barnett et al., 1996).

$\mathrm{O}$ alojamento de matrizes e suas leitegadas em um sistema familiar, em grupos de quatro, com acesso à palha, não aumentou a mortalidade dos leitões e determinou taxas mais altas de crescimento dos leitões em comparação a matrizes alojadas individualmente em celas parideiras (Arey \& Sancha, 1996). Matrizes em lactação mantidas em um sistema ao ar livre tiveram um comportamento materno mais intenso do que as alojadas em celas parideiras, o que pode contribuir para a sobrevivência dos leitões (Dalla-Costa et al., 2000).

Um fator de descarte de matrizes é quando estas mordem e matam os leitões durante o parto, as marrãs que atacam os leitões são mais sensíveis à frustração do comportamento de construção do ninho devido à ausência de palha. Por outro lado, marrãs que puderam construir o ninho antes do parto foram menos reativas aos leitões e tiveram menor intervalo parto-primeira mamada, o que pode contribuir para a viabilidade da leitegada (Damm et al., 2000). 
Um estudo sobre o comportamento materno de matrizes de linhagens diferentes demonstrou que marrãs selecionadas para alto crescimento de tecido magro com restrição alimentar mudaram menos de postura durante o parto, indicando que ficaram mais calmas do que as selecionadas para consumo de ração, conversão alimentar e crescimento magro com alimentação à vontade (McPhee, 2001).

Há duas grandes vertentes de conduta para melhorar o bem-estar animal. Uma delas é o chamado "enriquecimento ambiental", que consiste em introduzir melhorias no próprio confinamento, com o objetivo de tornar o ambiente mais adequado às necessidades comportamentais dos animais.

São exemplos de medidas na direção do enriquecimento ambiental:

- colocação de objetos, como correntes e "brinquedos" para quebrar a monotonia do ambiente físico. Isto reduziria a incidência de canibalismo (tem efetividade relativa);

- palha no piso, sobre o cimento, evitando piso ripado, reduz canibalismo;

- área mínima por porco em terminação de $1 \mathrm{~m}^{2}$, sem piso ripado e com palha ao lado do comedouro, estando o bebedouro do lado oposto, reduz agressão, e os animais separam a área de excreção (próximo ao bebedouro) da área de descanso;

- gaiolas parideiras com espaço suficiente para a matriz virar-se, com colocação de palha para construção do ninho.

A outra vertente seria repensar o sistema criatório como um todo, ou propor sistemas criatórios alternativos. O sistema de criação intensiva de suínos ao ar livre, introduzido em Santa Catarina desde 1987 pelo agrônomo João Augusto Vieira de Oliveira, da atual EPAGRI, e que a EMBRAPA chama de "SISCAL", tem sido adotado em vários países, com variações, tamanho do piquete, número de porcas por cabana e tipos de comedouro, que guardam a mesma característica de criar os suínos a céu aberto e com abrigo em cabanas.

Esse sistema ocasiona um índice menor de problemas comportamentais. Comparando o comportamento de matrizes e leitões no sistema confinado e no sistema ao ar livre, a ocorrência de comportamentos anômalos, canibalismo e agressão no sistema ao ar livre foi muito menor do que no confinado, indicando um maior bem-estar dos animais criados ao ar livre. Também o sistema ao ar livre tem implicações positivas 
no ambiente, na saúde animal e no balanço energético da criação. Implica investimentos muito menores (mesmo considerando a terra) e tem como resultado possibilidade de produção de um animal “orgânico", com alto valor de mercado (Leite et. al., 2001).

Outro sistema alternativo para a criação de suínos é conhecido como Pig Family Housing, (Stolba, 1989). Desenvolvido com base nos padrões comportamentais de suínos em condições naturais ou a campo extensivamente, é um sistema em que quatro porcas e um cachaço dividem um mesmo espaço, como se fossem moradores de um "condomínio". Cada porca fica alojada em um "apartamento". Os apartamentos comunicam-se entre si e o cachaço circula livremente entre eles. Os leitões convivem desde cedo com o grupo, o que evita os problemas de agressão, quando são desmamados e reagrupados em lotes de recria. Nos espaços para cada animal, há uma área separada para excreção, coberta com barro, sendo o restante do piso coberto com palha. O Pig Family Housing também promove o bem-estar animal, embora seja um confinamento e implique em investimento inicial mais alto que o confinamento intensivo.

$\mathrm{Na}$ Inglaterra, a criação intensiva de suínos ao ar livre vem tendo crescente incremento. A palha é um importante componente ambiental influenciando favoravelmente o bem-estar do suíno. Nos sistemas confinados, o uso de palha ou outro substrato similar, cobrindo o piso, tem impacto na manifestação comportamental de alguns, impropriamente chamados, "vícios" entre os animais. Os resultados obtidos por Lohmann, citado por Steiger (1978), mostram como o tipo de piso e a presença de palha afetam a incidência de canibalismo em suínos. Embora esses resultados sejam conhecidos desde 1966, somente na década de 90 começaram a ocorrer mudanças significativas nas recomendações e uso de palha e piso não ripado nas instalações para suínos. E esta mudança ocorre menos por razões “técnicas”, embora elas sejam válidas e conhecidas, e mais pela influência da opinião pública.

Se hoje o tema de maior evidência na pecuária é a rastreabilidade, compreendida pela necessidade de cada animal apresentar sua identificação para atender exigências de importadores da nossa carne, o bem-estar animal é o próximo item da lista. Na União Européia, bovinos, suínos e aves já ganharam legislação específica que determina desde o volume de produção por metro quadrado às práticas de nutrição, sanidade e abate, 
seguindo um conjunto de normativas. Como a UE é um mercado potencial para nossas exportações de produtos de origem animal, a qualquer momento chegarão por aqui as novas regras de produção necessárias para atender às exigências dos compradores europeus, como ocorre hoje em relação à rastreabilidade.

\subsubsection{Alojamento em baias individuais}

Uma das vantagens das baias individuais, em comparação ao alojamento de matrizes gestantes em grupo, é a redução dos comportamentos agressivos, do número de lesões, disputa por alimento e dificuldade no manejo individualizado dos animais nesta fase (Anil et al., 2002).

Porém, baias individuais podem ter efeitos adversos nos índices de bem-estar. Taylor et al. (1988) relatam que matrizes gestantes alojadas em celas individuais reduziram o número e o tempo de variações de posturas, quando comparadas com animais criados à solta em grupos. Embora a liberdade de movimento seja um dos critérios principais para avaliar o bem-estar dos animais, também se caracteriza como o índice mais controverso para avaliação do sistema de alojamento, partindo-se da premissa de que o animal tenha controle, até certo ponto, de seu ambiente, de forma que não tenha que fazer qualquer ajuste, pressupondo que as condições ideais para os mesmos sejam bem compreendidas e que todos os animais apresentem exigências semelhantes (Webster, 1993).

Devido ao reduzido dimensionamento das baias individuais de gestação $(2,00 \mathrm{x}$ $1,10 \times 0,80 \mathrm{~m}$ ), Anil et al. (2002) estudaram a postura comportamental de porcas nulíparas em relação às dimensões das baias de gestação e o tamanho das porcas, evidenciando três parâmetros comportamentais: duração de postura, freqüência de mudança de postura e tempo gasto para mudança de postura, sendo que os dois parâmetros iniciais não necessariamente indicaram limitação na liberdade de movimento animal. Porém, o tempo gasto para mudança de postura dentro do espaço restrito, ou seja, a dificuldade com que o animal em uma baia pode se levantar e deitar-se é certamente um indicador da liberdade de movimento animal. 
Estas suposições são discutíveis à medida que se ampliam estudos relacionados à postura comportamental de matrizes suínas, haja vista que a duração e a freqüência de necessidades de postura não necessariamente representam uma condição de desconforto animal, porque estes sinais podem fazer parte da estratégia de ajuste do animal ao ambiente, sem que haja nenhum valor ótimo por estes indicadores (Gonyou, 1996).

Os rigorosos procedimentos de seleção para melhorar a produção de carne mudaram a forma do corpo dos suínos domésticos modernos (Whittemore, 1994), resultando em dificuldade ao levantar-se e ao deitar-se. A maioria das baias individuais de gestação é dimensionada baseando-se nas exigências espaciais estáticas da matriz (em pé e deitada) (Marchant \& Broom, 1996). Na realidade, durante o ato de se levantar e deitar, o corpo movimenta-se além dos limites da exigência espacial estática, destacando-se neste momento as exigências espaciais dinâmicas, movimentos para o lado, adiante e para trás. O problema de restrição de espaço aumenta com o avanço da gestação. Baxter \& Schwaller (1983), relacionando o comprimento, largura e altura das matrizes em relação às dimensões correspondentes de gaiolas de gestação disponíveis comercialmente, verificaram problemas no alojamento de $95 \%$ dos animais em estudo, evidenciando o subdimensionamento dos modelos testados.

Estudos mais recentes revelaram que o tempo gasto para mudança de postura em matrizes confinadas em gaiolas de gestação é certamente um indicador da liberdade de movimento e de conforto animal, e que o problema de restrição de espaço se acentua com o desconforto fisiológico e aumento de tamanho do animal com o avanço da gravidez (Anil et al., 2002).

A privação dos animais da liberdade de movimento, falta de estímulos ambientais e interações sociais poderia afetar a saúde, desempenho e bem-estar global (Jensen et al., 1995). O alojamento limitado de matrizes reprodutoras é uma preocupação clara de ativistas em muitas partes do mundo. Na realidade, muitos países, como o Reino Unido, Países Baixos e Suécia baniram o uso de coleiras e gaiolas para matrizes gestantes por entenderem que estes sistemas de contenção não contemplam as exigências de bem-estar dos animais. 


\subsubsection{Alojamento em baias coletivas}

De acordo com a diretiva 2001/88/CE, será obrigatório manter todas as matrizes reprodutoras, porcas e/ou marrãs em grupos, durante um período de quatro semanas após inseminação até uma semana antes da data prevista para o parto, norma que deverá ser atendida pelos países membros e parceiros fornecedores de carne suína, a partir de 2013.

$\mathrm{O}$ estresse social normalmente ocorre entre animais desconhecidos. $\mathrm{O}$ confronto direto estabelece uma posição social relativa (Meese \& Ewbank, 1973) reduzindo, assim, a necessidade de agressão para resolver disputas futuras entre os mesmos. Observa-se que, em grupos recém formados, todos indivíduos são envolvidos em interações agressivas, em que matrizes dominantes se envolvem na maioria das agressões (Barnett et al., 1992; Mount \& Seabrook, 1993; Moore et al., 1993; Arey \& Franklin, 1995). A estabilidade social relativa é alcançada depois de 2 (Bauer \& Hoy, 2002), 3 (Oldigs et al., 1993) ou 10 dias (Van Putten \& Van de Burgwal, 1990) entre matrizes alojadas em baias coletivas. Uma vez um grupo estabelecido, as matrizes podem se lembrar de indivíduos durante mais de 1 semana (Olsson \& Svendsen, 1995) até 4 semanas (Spoolder et al., 1996) e talvez até mesmo 6 semanas, no caso de indivíduos de posição dominante (Ewbank \& Meese, 1971).

A agressão que ocorre no momento da introdução de matrizes gestantes em grupos alojados em baias coletivas pode resultar da tensão fisiológica causada pela fase inicial de prenhes (Arey \& Edwards, 1998), e tais respostas podem ter efeitos prejudiciais em parâmetros reprodutivos, como um retorno ao cio, aborto e um número reduzido de leitões nascidos vivos. Desta forma, a estratégia desenvolvida para se agrupar matrizes gestantes, procurando minimizar o efeito da agressividade entre os animais, foi o manejo em baias individuais, da detecção do cio à inseminação, até 28 dias após inseminação dos animais, evitando a formação de grupos no momento de alto estresse, em função da tensão fisiológica proveniente do início de gestação (Bauer \& Hoy, 2002).

O reagrupamento de matrizes, após o desmame dos leitões, pode ser um evento de altíssimo estresse e motivo de preocupação no que se refere ao bem-estar dos animais na produção industrial de suínos. A interação agonística, resultante da mistura de animais desconhecidos, normalmente promove comportamentos agressivos, ameaças, empurrões, 
mordidas, perseguições e brigas, que conduzem à formação de uma hierarquia social estável (Meese \& Ewbank, 1973; Mount \& Seabrook, 1993).

Barnett et al. (1992) registraram 68 interações em um período de $90 \mathrm{~min}$ depois de misturar grupos de seis animais. Pritchard (1996) registrou 60 interações durante um período de observação de $60 \mathrm{~min}$, também com um grupo de seis matrizes, verificando uma redução gradual de agressões no decorrer de 15 horas, com cumes menores de agressão durante o período de 2 dias. O número de interações agressivas resultantes do agrupamento pode ser correlacionado com a quantidade de lesões encontradas nos animais (Barnett et al., 1992), podendo prover uma medida útil de bem-estar (Barnett et al., 1996).

Em algumas situações, podem-se verificar agressões dentro de um nível aceitável de bem-estar, em virtude do estabelecimento de grupos sociais em que os subordinados podem sofrer agressões como resultado de competição por recursos, como comida e espaço (Petherick \& Blackshaw, 1987). O período necessário para a redução da agressividade entre os animais e o estabelecimento de uma hierarquia social relativamente estável é de 3 a 10 dias (Van Putten \& Van de Burgwal, 1990; Oldigs et al., 1993). Porém, outros estudos relataram períodos maiores de tempo, até 6 semanas, para que as matrizes se tornassem completamente integradas, quando inseridas em novos grupos (Moore et al., 1993; Spoolder et al., 1996; Arey, 1999). Manifestações severas de tensão social podem conduzir a atraso no estro, aborto, aumento no período de gestação e fracasso na lactação (Hansen \& Vestergaard, 1984; Bokma, 1990; Te Brake \& Bressers, 1990; Varley \& Stedman, 1993).

\subsection{Sistemas inteligentes aplicados à suinocultura}

\subsubsection{Identificação eletrônica}

Nas últimas décadas, o aumento da produção de suínos, pressionada por uma crescente procura de alimentos, tem-se caracterizado por um aumento no tamanho e na concentração de animais nas unidades de produção, dificultando o registro dos dados de cada animal em particular. Os sistemas automáticos de identificação eletrônica podem 
auxiliar na detecção de doenças, resposta fisiológica ao estresse ambiental, ingestão de alimentos, atividade física e o impacto ambiental causado pelo sistema de produção, promovendo melhor controle na propriedade. Transponders injetáveis e brincos eletrônicos estão sendo utilizados no processo de identificação eletrônica (Rossing, 1999).

A União Européia preconiza a identificação de todos os animais (bovinos, suínos, caprinos e ovinos) para total controle do nascimento à linha de abate, definindo um padrão mundial para os dispositivos eletrônicos de identificação, assegurando a compatibilidade entre os sistemas dos diferentes fabricantes, possibilitando, dessa maneira, a ampla projeção do registro e identificação de todos os animais (Wismans, 1999).

Seja qual for o dispositivo, um identificador eletrônico possui um transmissor que emite um número de série o qual permite identificar o animal e monitorar a sua atividade. É possível distinguir os princípios de funcionamento dos diferentes sistemas portadores de informação e reconhecimento, aplicados à identificação.

O uso de transmissores pode ser mais interessante no caso de animais de reprodução, que permanecem mais tempo na propriedade. Além do sistema do consumo de ração, o sistema também pode ser usado para registrar as cobrições, vacinações, nascimentos, desmames, etc. Com registros adequados, as cobrições mais recomendáveis podem ser especificadas, em função do grau de parentesco dos animais e da data de utilização do macho. Informações semelhantes podem ser utilizadas para inseminação artificial (Fialho, 1999).

Uma fazenda experimental da Universidade do Estado de Iowa combinou um sistema de alimentação com a identificação eletrônica de porcas em gestação, em um rebanho não confinado, permitindo à porca exercitar-se durante o período de gestação e conviver em grupos sociais, porém mantendo o controle do fornecimento de ração e ganho diário de peso, quando comparados a duas formulações distintas. O sistema de alimentação eletrônico torna-se de grande eficiência, quando os animais são alojados em grupos, controlando a necessidade nutricional de cada porca, evitando comportamentos 
agressivos dentro do rebanho e garantindo controle do peso, assegurando a máxima produtividade e aumentando a longevidade do rebanho (Hoff, 1998).

\subsubsection{Análise de imagem}

A avaliação tradicional e o controle do ambiente na produção de animais confinados são baseados principalmente na temperatura do ar. Tal aproximação apresenta problemas inerentes, por não se tratar de um método interativo com as necessidades dos animais, pois, a temperatura do ar, exclusivamente, não representa o ambiente térmico como um todo, o que também inclui variáveis como umidade (especial em circunstâncias quentes), radiação (em instalações mal isoladas), tipo e condição do piso (seco e/ou molhado), variações na condição nutricional e de saúde dos animais.

O conjunto dessas variáveis apresenta a verdadeira necessidade ambiental dos animais. Contudo, faz-se necessário o registro de todos os fatores internos e externos para se produzir um índice detalhado de conforto para a avaliação e o controle de sua produção (Wouters et al., 1990).

Em ambientes agropecuários controlados, tal como as instalações de produção animal, torna-se necessário o uso de técnicas de controle das variáveis ambientais. A prévia detecção de condições prejudiciais ou irregulares é muito importante, por envolver produtos de valor elevado e o alto custo no sistema de produção. Estas propriedades são controladas geralmente com algum tipo de equipamento local com supervisão humana (Cox, 1988).

Os peritos usam freqüentemente a informação visual dos animais para o diagnóstico, mesmo antes de toda a condição de alarme ser detectada por meio de sensores e instrumentos, que auxiliam na análise da resposta das variáveis, relacionandoas aos dados de produtividade para a detecção de problemas (Xin et al., 1998).

O problema é que, às vezes, o especialista que possa diagnosticar corretamente uma condição anormal pode não estar no local para executar uma análise visual, sendo interessante fornecer o acesso remoto à informação visual em tempo real, sempre que este for necessário. As câmeras de vídeo podem facilmente ser usadas para essa 
finalidade, fornecendo informações pertinentes ao gerente, proprietário ou a um consultor, para a tomada de decisão (Lopes et al., 2002).

Dusenbery (1985) demonstrou a viabilidade de se observarem, simultaneamente, 25 aves por meio do uso de microcomputador e de uma câmera de vídeo. O autor descreveu a possibilidade de registro individual e simultâneo dos movimentos efetuados por 25 animais, sendo possível obter dados do comportamento dos animais por meio de um equipamento relativamente barato que proporcionou o registro e o processamento das imagens em tempo real.

A avaliação e os controles interativos do conforto térmico dos suínos pela análise de imagem superam os problemas inerentes ao método convencional, pois, utilizam-se os próprios animais como um biosensor em resposta aos reflexos do ambiente, através da análise comportamental (Xin \& Shao, 2002).

O sistema consiste em uma microcâmera, uma placa de captura de imagem instalada em um PC e um programa visual que executa a aquisição, processamento e a classificação das imagens dos animais (Xin et al., 2002).

Shao et al. (1997) e Shao et al. (1998) relataram os parâmetros comportamentais por imagens, como variáveis de entrada a uma rede neural artificial (RNA) para a classificação do estado do conforto térmico para suínos, possibilitando o desenvolvimento de um sistema automatizado, em tempo real, pela análise de imagens, que permitiu a avaliação e o controle contínuo do conforto térmico dos suínos confinados, baseados em seus testes padrões de comportamento.

\subsubsection{Lógica fuzzy}

De forma objetiva e preliminar, pode-se definir lógica fuzzy como sendo uma ferramenta capaz de capturar informações vagas, em geral descritas em uma linguagem natural e convertê-las para um formato numérico, de fácil manipulação pelos computadores atuais, ou seja, suporta os modos de raciocínio que são aproximados, ao invés de exatos, como se esta naturalmente acostumado a trabalhar. Considerando a seguinte afirmativa: "Se o tempo de um investimento é longo e o sistema financeiro tem sido não muito estável, então a taxa de risco do investimento é muito alta." Os termos 
"longo", "não muito estável" e "muito alta" trazem consigo informações vagas. A extração (representação) destas informações vagas se dá através do uso de conjuntos nebulosos.

A teoria fuzzy se baseia no princípio de que o pensamento humano é estruturado não em números, mas sim em classes de objetos, cuja transição entre pertencer ou não a um conjunto é gradual e não abrupta, o que diferencia os humanos dos computadores digitais. Assim, enquanto as fronteiras dos conjuntos clássicos são bem definidas, as dos conjuntos fuzzy apresentam uma nebulosidade, a qual tenta se aproximar das impressões do modo de raciocínio humano (Cornelissen, 2002).

De acordo com Shaw \& Simões (1999), a lógica fuzzy providencia os fundamentos teóricos para a captura de incertezas associadas com os processos de pensamento humano, através do emprego de definições lingüísticas de variáveis utilizadas em um sistema com uma base de regras.

Os modelos fuzzy parecem ser ferramentas valiosas na forma como vinculam as informações mensuráveis para a interpretação lingüística, podendo avaliar os sistema de produção de ovos em relação ao interesse público sobre o bem-estar (Cornelissen, 2002).

Segundo a literatura (Zadeh, 1973; Altrock, 1995; Andrade, 1997), a utilização da lógica fuzzy é especialmente adequada a problemas de natureza biológica, pois estes apresentam as seguintes características:

- o processo é definido de maneira vaga, imprecisa, incerta;

- há ocorrência de situações de difícil estimação ou avaliação dos parâmetros que definem o processo;

- o sistema é não linear e variante no tempo;

- há ocorrência de situações nas quais é difícil o registro do valor das variáveis;

- as medidas podem ser pouco confiáveis.

Além disso, com a utilização de regras fuzzy e variáveis lingüísticas, o sistema monitorado passa a desfrutar das seguintes possibilidades:

- simplificação do modelo do processo;

- melhor tratamento das imprecisões inerentes aos sensores utilizados; 
- facilidade de especificação das regras de controle, em linguagem próxima à natural;

- satisfação de múltiplos objetivos de controle;

- facilidade de incorporação do conhecimento de especialistas humanos;

\subsubsection{Conjuntos Fuzzy}

A teoria de conjuntos fuzzy foi introduzida por Lotfi Asker Zadeh em 1965, como uma teoria matemática aplicada a conceitos vagos. Desde então, a pesquisa e aplicação desta teoria em sistemas de informação têm crescido. Uma área de aplicação da teoria fuzzy é a chamada raciocínio aproximado, pois não é totalmente certo nem totalmente errado. Este tipo de lógica se aproxima da forma do pensamento humano. Nestes casos, variáveis lingüísticas são representadas por conjuntos fuzzy, interpretando uma variável lingüística como uma variável cujos valores são palavras ou sentenças em uma linguagem natural. Conjuntos fuzzy proporcionam, aos métodos de desenvolvimento de sistemas computacionais, uma forma de programação mais próxima da linguagem e do raciocínio humano, ou seja, a dualidade nas respostas, além da existência de variação nas opções (Zadeh, 1965).

Uma variável lingüística, cujos valores são etiquetas ou predicados lingüísticos associados a conjuntos fuzzy, pode ser, por exemplo, a temperatura de um dado processo assumindo os valores baixa, média ou alta. Estes valores são descritos por intermédio de conjuntos fuzzy (Gomide, 1995).

Nesse sentido, a introdução dos conhecimentos da teoria dos conjuntos fuzzy mostra-se inovadora. Firk et al. (2003) relatam melhoria na previsão de inseminação em vacas leiteiras, utilizando a base de dados de identificação do cio, quando comparado com métodos convencionais. Cveicanin (2003) apresenta uma metodologia de pesagem eletrônica para gado, em que um algoritmo foi desenvolvido utilizando a lógica fuzzy. Para o dimensionamento de dietas para gado em condições de semi-estabulação, Cadenas et al. (2003) estipularam um cenário, usando a programação linear fuzzy, associada a um processo de tomada de decisão. 
As principais áreas de aplicação da lógica fuzzy são: sistemas de controle fuzzy, tomada de decisão, reconhecimento de padrões e processamento de imagens, medicina, ecologia, banco de dados fuzzy, e aplicações em sistemas operacionais.

\subsubsection{Redes Neurais Artificiais}

Redes Neurais Artificiais (RNAs) ou simplesmente "Redes Neurais" são modelos de processamento serial ou distribuído paralelamente, procurando alcançar boas performances via interconexão de elementos computacionais simples. Os modelos de redes neurais têm grande potencial de aplicação na produção animal, em que se faz necessário uma imensa gama de dados, possibilitando a compreensão das relações entre o ambiente e a exploração agropecuária. Apesar de desenvolver um programa de instruções seqüenciais, os modelos de RNAs exploram muitas hipóteses simultaneamente, usando redes paralelas compostas de muitos elementos conectados por ligações de variáveis pesos (Kovács, 1996).

As RNAs são especificadas pela topologia de rede, nós característicos e regras de treinamento ou aprendizado. Essas regras especificam um peso inicial e indicam como esses pesos têm que se adaptar durante o uso para melhorar a performance. Ambos os procedimentos e regra de treinamento são temas de muitas pesquisas (Astion \& Wilding, 1992; Roush et al., 1996; Xin, 1999; Kominaks et al., 2002). Os "neurônios" da rede podem receber entradas excitatórias ou inibitórias de outros neurônios (Forsström \& Dalton, 1995) e produzem uma saída, que geralmente é uma função não linear da entrada da rede (Astion \& Wilding, 1992). Em contraste com muitos sistemas especialistas, as redes neurais artificiais não dependem de algoritmos pré-definidos (Lee et al., 1999).

Fenômenos complexos ou aqueles que envolvem variáveis conhecidas como causalmente dependentes, mas cuja dependência está muito além de uma simples relação linear ou não linear, têm sido objeto para aplicação e desenvolvimento de modelos com RNAs. Redes neurais, mesmo que implementadas com sucesso, permitem apenas simular ou emular o fenômeno estudado, não oferecendo por si só a possibilidade de se 
simplificar, generalizar ou reduzir sua teoria. Neste sentido, podem ser consideradas como uma ferramenta que funciona, mas não se sabe por que (Kovács, 1996).

Forsström \& Dalton (1995) afirmaram que, à medida que o aprendizado ocorre, o erro entre a saída da rede e a saída desejada diminui. Então, o conhecimento, o qual a rede aprende, está codificado nos pesos das conexões entre neurônios. Devido ao fato de tal conhecimento estar distribuído através dos pesos, é quase impossível interpretar o conhecimento, o qual foi aprendido por qualquer rede de retropropagação. Este é o motivo pelo qual as RNAs são freqüentemente chamadas de "caixas pretas". Elas aprendem a calcular uma saída corretamente, a partir de um padrão de entrada, mas raramente revelam o conhecimento que está por trás dos seus julgamentos.

O modelo matemático de um neurônio artificial foi primeiramente idealizado pelos pesquisadores W. S. McCulloch e W. H. Pitts (Zurada, 1992) no ano de 1943. Compõese basicamente de conexões e pesos de entrada emulando os dendritos e sinapses, de uma função de mapeamento emulando o corpo celular, e uma saída emulando o axônio, conforme exemplificado na Figura 1.

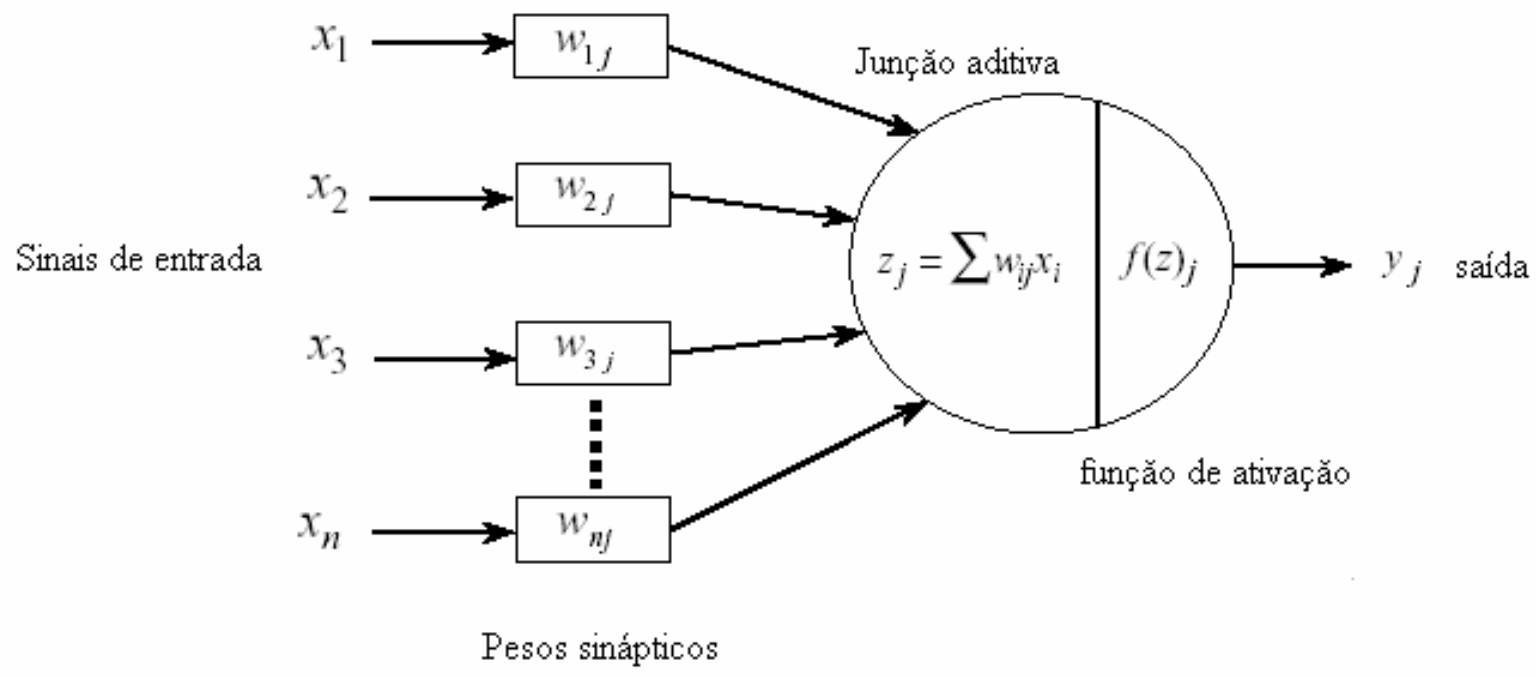

Figura 1 - Modelo genérico do neurônio artificial 
Não existe nenhum procedimento determinístico para estruturar uma rede. Esta é feita de forma heurística, sendo que os parâmetros mais relevantes são os seguintes:

- número de camadas (“layers”);

- número de neurônios por camada;

- topologia das interconexões;

- função de transferência;

- representação dos dados;

- dinâmica de operação.

Cabe ressaltar que o aumento do número de camadas acarreta o aumento da complexidade e do tempo de processamento da rede. $\mathrm{O}$ aumento do número de neurônios por camada acarreta o aumento do grau de liberdade da função de transferência, e quanto maior a quantidade de variáveis livres, menor será a capacidade de generalização da rede. Logo, o objetivo de projeto é resolver o problema com a menor estrutura possível.

As principais vantagens da utilização de uma RNA são: tolerância a falhas; aplicações em tempo real; alta capacidade de auto-adaptação; capacidade de resolver problemas práticos, sem a necessidade da definição de listas de regras ou de modelos precisos. Por outro lado, os principais pontos negativos são: conhecimento aprendido não pode ser expresso em regras, ou seja, não existe uma equação inteligível que possa ser mostrada; a validação da rede é mais difícil do que em estatística convencional; as redes neurais precisam de muitos exemplos para serem adequadamente treinadas e validadas.

As redes neurais artificiais oferecem melhores abordagens para problemas que requeiram: reconhecimentos de padrões; classificação de padrões; associação de padrões; identificação; aproximação de funções e aprendizado. Dentre as principais áreas de aplicação, podem-se citar: áreas onde é difícil criar modelos precisos da realidade e problemas com freqüentes mudanças de ambiente (Haykin, 2001). 


\subsubsection{Uso das redes neurais artificiais na agropecuária}

Com o avanço da informática, a utilização de sistemas computacionais para a predição de eventos biológicos, com base em históricos individualizados de produção, ganha cada vez mais importância no gerenciamento agrícola, destacando-se como uma importante ferramenta na tomada de decisão.

De acordo com Kominaks et al. (2002), estudos preliminares para predição da produção diária de leite em ovelhas em lactação, por meio do uso de RNAs, permitiram um adequado planejamento do fluxo de produção com base nos parâmetros fisiológicos e ambientais.

Xin (1999) desenvolveu um sistema automatizado de análise de imagens, que fornece conforto térmico para suínos e que faz os ajustes ambientais apropriados para melhorar o bem-estar animal e a eficiência produtiva, adotando-se o animal como um biosensor. Em um primeiro momento, o autor examinou a viabilidade de classificar o conforto térmico de leitões por rede neural, a partir de suas imagens posturais. Foi incluída uma pesquisa das imagens de comportamento postural como entrada em uma rede neural de retropropagação com três camadas, a qual foi treinada para classificar o estado de conforto térmico correspondente, como sendo frio, confortável ou quente.

Roush et al. (1997) utilizaram a rede neural como uma predição probabilística, probabilistic neural network (PNN). A rede foi treinada para predizer ascite, baseada em fatores minimamente invasivos, isto é, fatores fisiológicos que não necessitam da morte da ave. Uma PNN é uma rede neural artificial supervisionada e com três camadas, que classifica padrões de entrada, dados fisiológicos, em categorias específicas de saída, detecção ou não de ascite. As entradas da PNN foram: nível de $\mathrm{O}_{2}$ no sangue, peso corporal, eletrocardiograma, hematócrito e taxa cardíaca das aves. A conclusão foi que o uso dos modelos desenvolvidos pode intensificar o diagnóstico de ascite em frangos de corte. Os resultados podem ser úteis na escolha e no desenvolvimento de linhagens de frangos de corte que não tenham propensão a desenvolver ascite.

Roush \& Cravener (1997) compararam dois tipos de redes neurais artificiais, retropropagação e rede neural de regressão geral, para predição de níveis de aminoácidos 
em ingredientes alimentares. Além disso, os autores compararam tais redes neurais frente a técnicas de análise de regressão. As redes neurais artificiais tiveram um melhor desempenho do que a análise de regressão, sendo que, naquele caso, a rede neural de regressão geral superou a de retropropagação. 


\section{MATERIAL E MÉTODOS}

O experimento foi realizado em uma granja comercial, cuja principal atividade é a produção industrial de suínos, localizada no município de Elias Fausto, SP, sendo hoje um laboratório experimental do NAP - NUPEA/USP, apresentando latitude de $22^{\circ} 36^{\prime} \mathrm{S}$, longitude de $47^{\circ} 36^{\prime} \mathrm{W}$ e altitude de $535 \mathrm{~m}$. O clima da região é caracterizado como mesotérmico Cwa (tropical de altitude), com temperatura do mês mais frio entre 3 e $18^{\circ} \mathrm{C}$, com inverno seco e temperatura do mês mais quente maior que $22^{\circ} \mathrm{C}$, segundo classificação Köppen (Pereira et al., 2002).

O desenvolvimento da pesquisa foi na fase de gestação, no período compreendido entre 04/01/2005 e 11/03/2005, com duração média de 67 dias. O experimento foi dividido basicamente em três etapas, em função da forma de avaliação dos dados:

- análise bioclimática;

- análise dos sistemas de produção;

- aplicação de sistemas inteligentes disponíveis, lógica fuzzy e redes neurais artificiais (RNAs) para o estudo de padrões de conforto e predição de índices zootécnicos.

\subsection{Análise bioclimática}

\subsubsection{Variáveis meteorológicas}

Foram monitoradas as variáveis meteorológicas e ambientais (concentração de gases), na sala de gestação e no ambiente externo. As variáveis meteorológicas foram registradas por meio de sensores instalados em pontos estratégicos no interior da instalação, e no ambiente externo, conectados a uma plataforma automática de registro de dados: temperatura de bulbo seco (Ts), umidade relativa do ar (UR), temperatura 
de ponto de orvalho (Tpo), temperatura de globo negro (Tg) e umidade absoluta (UA).

O registro das variáveis meteorológicas foi realizado em intervalos de 15 minutos, durante o ciclo de gestação das matrizes selecionadas para o estudo. As variáveis meteorológicas foram registradas por um microprocessador da marca Hobo, modelo H08-00X-02, equipado com sensor de temperatura externa (globo negro). Sua faixa de operação encontra-se entre $-20^{\circ} \mathrm{C}$ e $+70^{\circ} \mathrm{C}$, e umidade relativa de 0 a $95 \%$, sem condensação ou névoa. Os equipamentos foram instalados em pontos estratégicos no interior da instalação a uma altura de $1,30 \mathrm{~m}$ do piso, dispostos pontualmente na condição de alojamento em baias coletivas (Figura 2a) e baias individuais (Figura 2b), determinando, desta forma, o microclima proporcionado por cada um dos regimes de alojamento estudados.
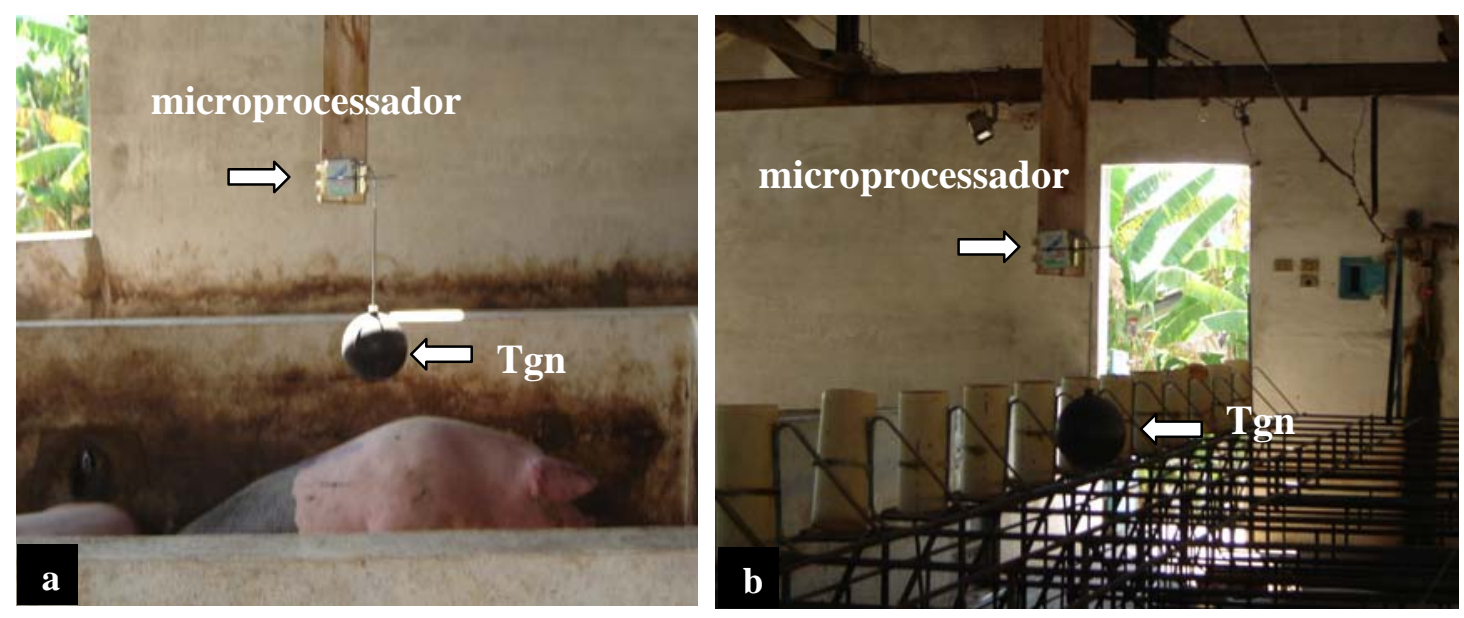

Figura 2 - Disposição do microprocessador para o registro das variáveis meteorológicas na condição de alojamento em baias coletivas (a) e baias individuais (b)

A determinação da velocidade do vento para o ambiente externo foi realizada por meio de um anemômetro mecânico, composto por um conjunto de três canecas. O número de giros das canecas, sendo proporcional à velocidade, é transformado em deslocamento por um sistema tipo odômetro. $\mathrm{O}$ espaço percorrido dividido pelo tempo fornece a velocidade média, permitindo o registro diário durante o período experimental. 
$\mathrm{Na}$ área externa às instalações, os sensores foram instalados a $1,5 \mathrm{~m}$ de altura da superfície, representando o microclima do local. A aquisição dos dados foi realizada por meio de um microprocessador da marca Hobo, modelo H08-00X-08, operando na faixa de $-30^{\circ} \mathrm{C} \mathrm{a}+50^{\circ} \mathrm{C}$, e sensor de umidade à prova de condensação com registro de dados entre 0 e $100 \%$ (Figura 3 ).

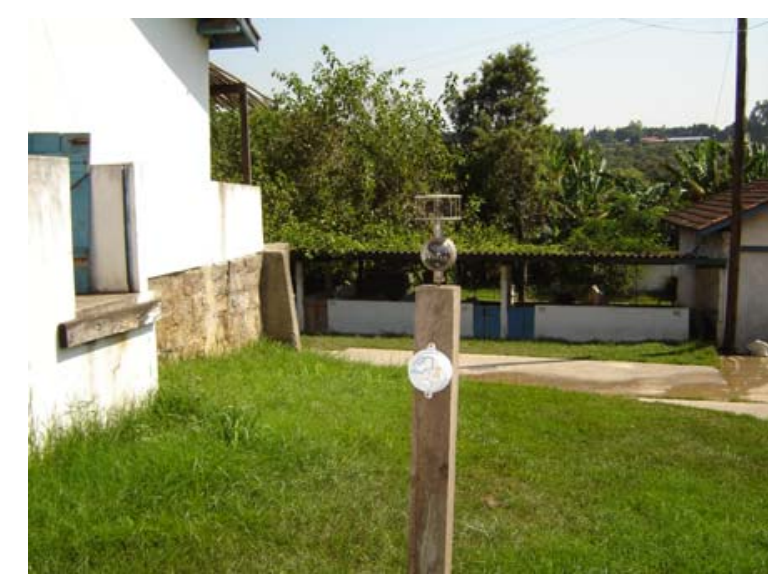

Figura 3 - Anemômetro e microprocessador blindado instalados no ambiente externo à instalação

Para determinação da eficiência térmica das instalações, com os dados referentes às variáveis meteorológicas registradas nos ambientes estudados, foram determinados o índice de temperatura de globo e umidade (ITGU) e entalpia específica h $\left(\mathrm{kJ} \cdot \mathrm{kg}^{-1}\right)$ por meio das seguintes equações:

a) índice de temperatura de globo e umidade (ITGU), proposta por Buffington et al. (1981):

$$
I T G U=T g+0,36 T p o-330,08
$$

Em que:

$T g=$ temperatura de globo negro $(\mathrm{K})$

$T p o=$ temperatura de ponto de orvalho $(\mathrm{K})$ 
b) entalpia (kJ.kg ar seco-1), proposta por Albright (1990):

$$
H=1,006 T s+W(2501+1,805 T s)
$$

Em que:

Ts $=$ temperatura de bulbo $\operatorname{seco}\left({ }^{\circ} \mathrm{C}\right)$

$W=$ razão de mistura ( $\mathrm{kg}$ vapor d'água.kg $\left.\mathrm{ar} \mathrm{seco}^{-1}\right)$

\subsubsection{Variáveis ambientais}

O registro da concentração de gases foi realizado semanalmente por amostragem completa da jornada, durante 8 horas ( 7 às 17 horas). No período de avaliação dos locais estudados, verificaram-se as concentrações dos gases existentes no ar, por meio de sensores eletroquímicos, $\mathrm{O}_{2}, \mathrm{CH}_{4}, \mathrm{NH}_{3}, \mathrm{CO}$ e $\mathrm{H}_{2} \mathrm{~S}$, instalados no centro geométrico da instalação a uma altura de 1,2 $\mathrm{m}$ do piso, utilizando o equipamento Commander para o monitoramento dos gases no interior da instalação. O sensor foi calibrado para registrar os dados a cada minuto (Figura 4).

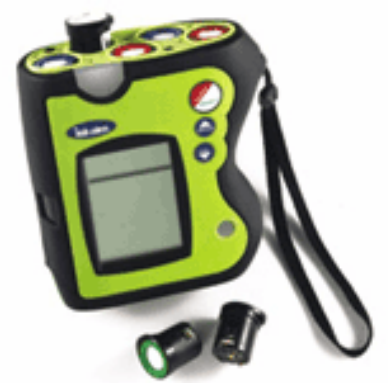

Figura 4 - Visualização do medidor de gases utilizado no experimento

\subsubsection{Tipologia da instalação estudada}

A instalação referente ao confinamento das matrizes gestantes é caracterizada tipologicamente por 60,0 $\mathrm{m}$ de comprimento por 15,0 $\mathrm{m}$ de largura, pé direito de 2,3 m, beiral de $0,5 \mathrm{~m}$ e orientação leste-oeste. Cobertura com telhas de cerâmica do tipo francesa, sem a presença de forro de revestimento, sendo que o sentido longitudinal da 
instalação apresenta fechamento lateral em alvenaria, com peitoril de $1,10 \mathrm{~m}$, totalizando uma área de abertura lateral de $144 \mathrm{~m}^{2}$.

As baias individuais de contenção possuem dimensões de $1,95 \mathrm{~m}$ de comprimento por 0,60 m de largura, por 1,20 m de altura, totalizando uma área de $1,17 \mathrm{~m}^{2}$, e um volume de $1,40 \mathrm{~m}^{3}$. O piso das baias é concretado, sendo que no terço final apresenta piso vazado confeccionado em concreto armado.

Com relação às baias coletivas, estas apresentam as seguintes dimensões: 4,80 m de comprimento, por 2,80 m de largura e muretas de contenção de $1,10 \mathrm{~m}$ de altura, dispondo no terço final da baia um ripado de bambu, de maneira a garantir sombreamento aos animais, como medida de proteção a possíveis doenças de pele, resultantes da exposição direta à radiação solar. Além disso, possui piso concretado sem substrato ou cama disponível, totalizando uma área livre de $13,44 \mathrm{~m}^{2}$, dispondo de 2,24 $\mathrm{m}^{2}$ por animal, sabendo-se que os grupos foram formados por seis animais no total.

O manejo do microclima no interior da edificação foi realizado concomitantemente com o acionamento dos sistemas de aspersão no telhado e de nebulização nas linhas das baias individuais, ou seja, ligavam-se os sistemas de climatização em dias em que a temperatura excedia os $30^{\circ} \mathrm{C}$, normalmente às 12 horas, permanecendo em funcionamento até as 17 horas, coincidindo com a mudança de turno dos funcionários da granja. Além disso, contava-se com aberturas no telhado, pela retirada de telhas, o que permitia maior dissipação do calor transmitido pela radiação e gerado pelos animais.

Foram alojadas na estrutura 380 matrizes, 270 em baias individuais e 110 animais em baias coletivas. A disposição dos sistemas de alojamento no sentido transversal da edificação caracteriza-se de forma que as baias coletivas ocupam uma das extremidades laterais, e as baias individuais, o restante de toda construção (Figura 5). 


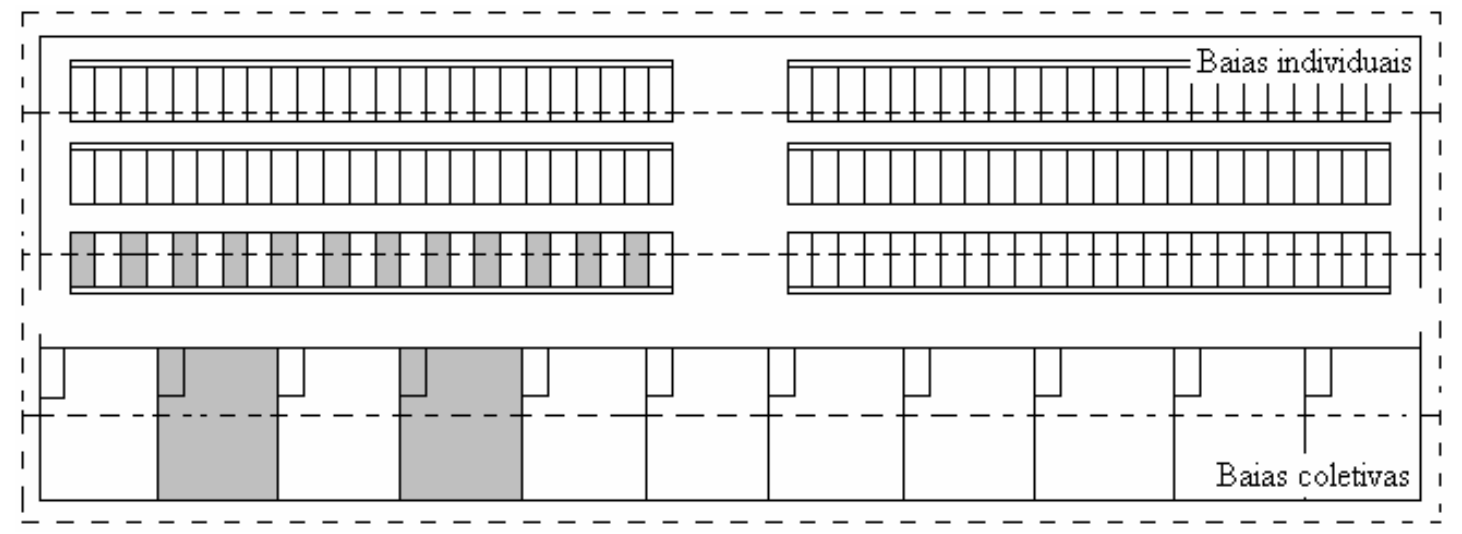

Figura 5 - Representação esquemática da distribuição dos tratamentos, baias individuais e coletivas no interior da instalação

\subsection{Análise dos sistemas de produção}

Foram avaliados dois sistemas de confinamento, considerados neste trabalho como tratamentos:

- Tratamento 1: Sistema de confinamento em baias individuais de gestação (Figura $6)$

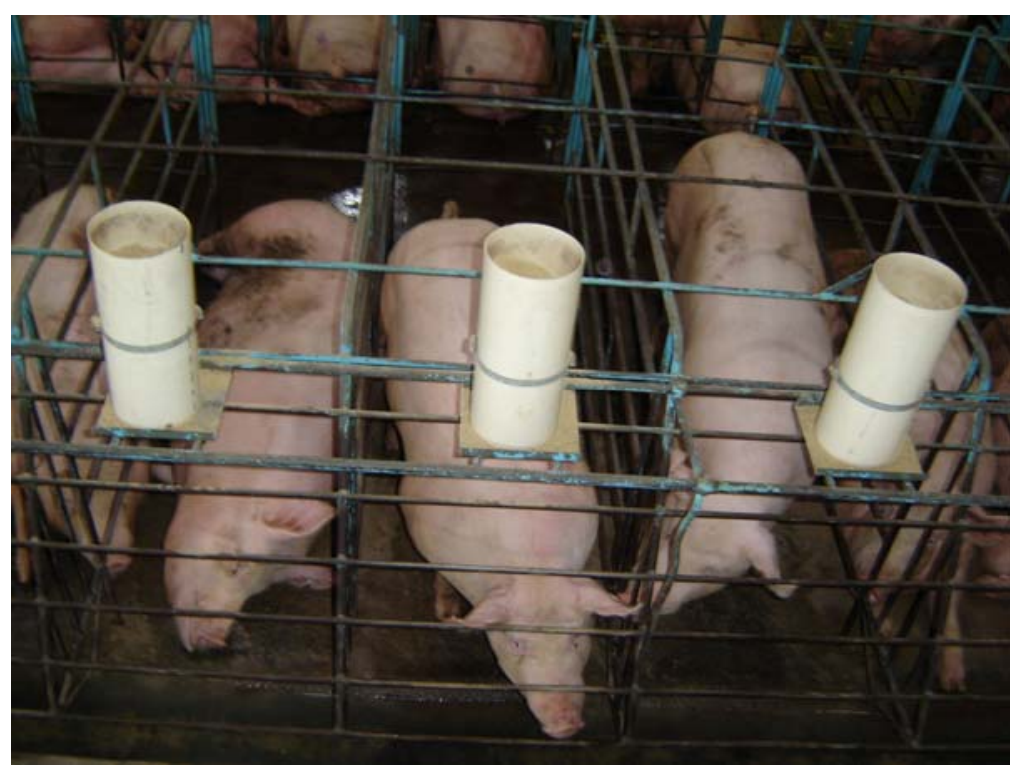

Figura 6 - Sistema de confinamento em baias individuais 
- Tratamento 2: Sistema de confinamento em baias coletivas (gestação) que permitem livre movimentação às matrizes (Figura 7).

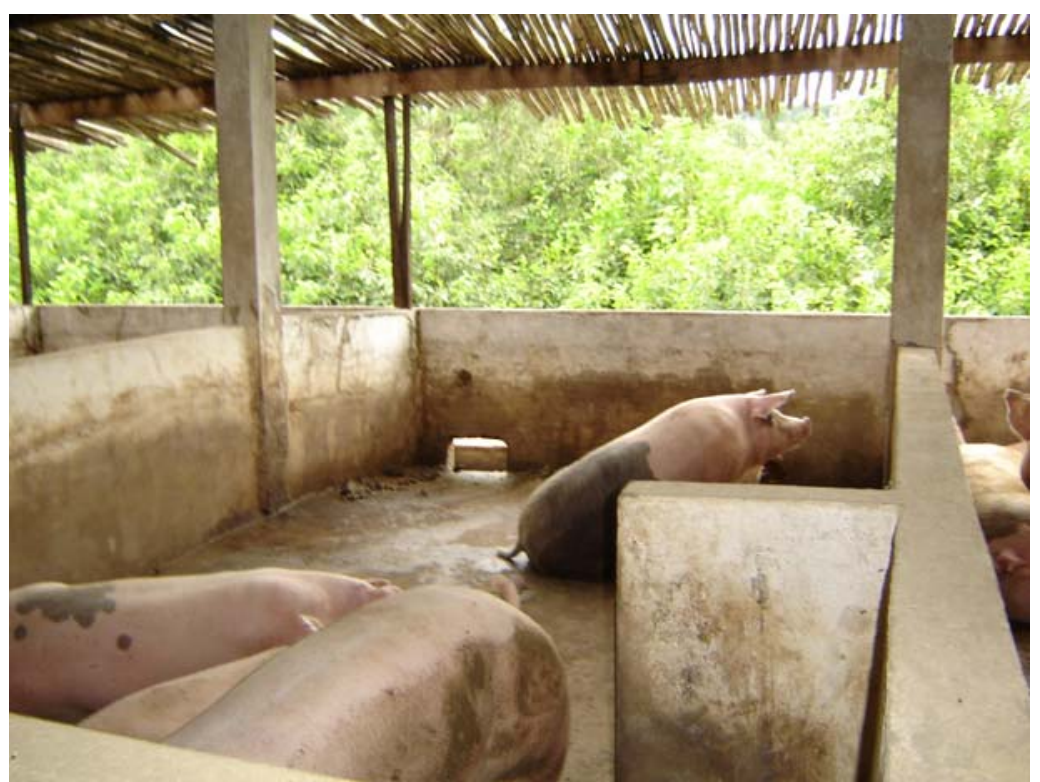

Figura 7 - Sistema de confinamento em baias coletivas

Como variáveis respostas a esses tratamentos foram avaliados as relações comportamentais, fisiológicas e índices zootécnicos, de acordo com o fluxograma apresentado na Figura 8. 


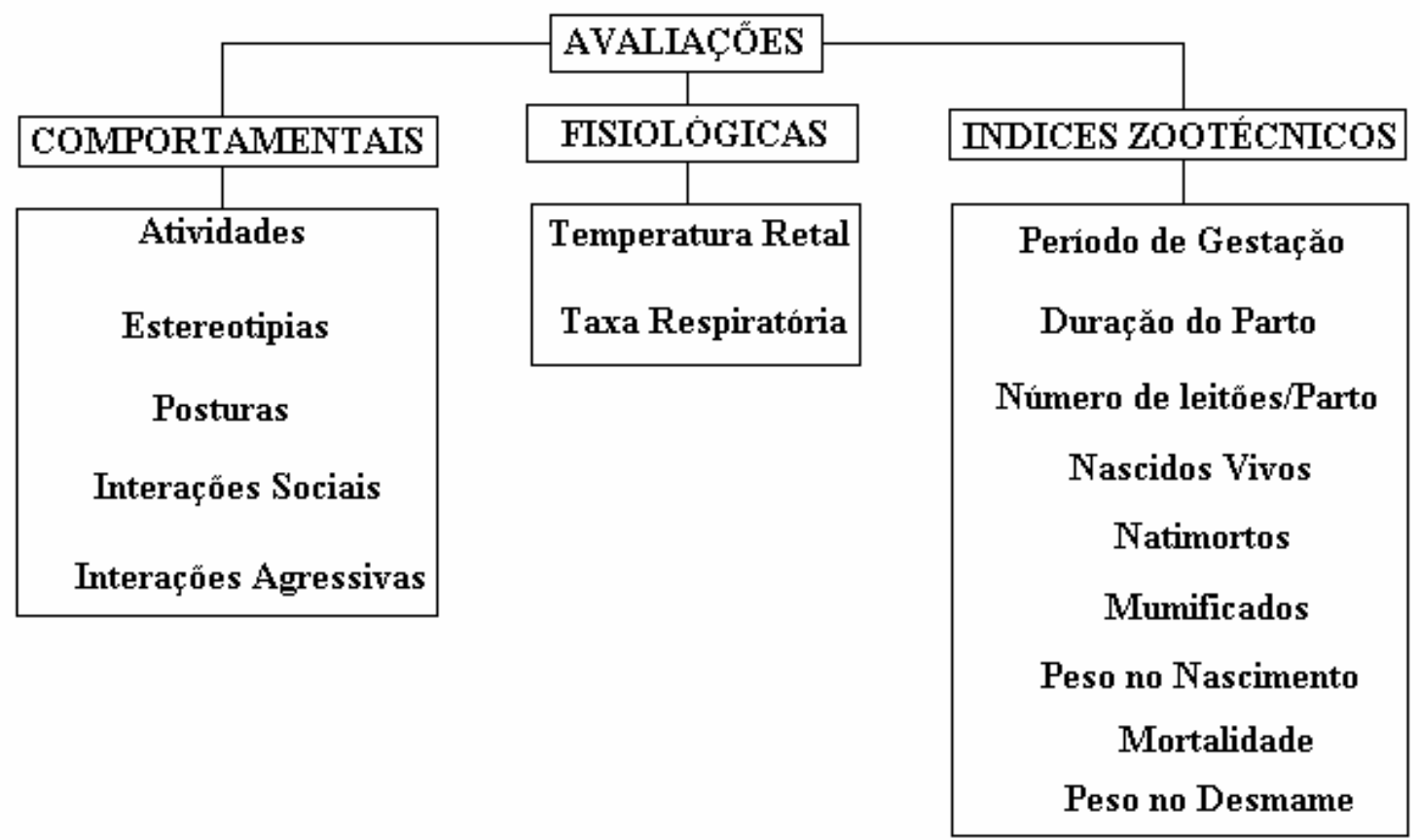

Figura 8 - Fluxograma das variáveis respostas dos diferentes sistemas de confinamento estudados, baias individuais (T1) e coletivas (T2)

\subsubsection{Variáveis comportamentais}

Antes de se iniciar as observações, foi desenvolvido um etograma comportamental, com base em gravações piloto que permitiram verificar quais os elementos comportamentais que possivelmente poderiam ser registrados em matrizes confinadas em celas individuais de gestação (T1) e em baias coletivas (T2). O etograma final (Tabela 2) foi desenvolvido de acordo com os ensaios preliminares e estudos desenvolvidos por O'Connell et al. (2004); Zonderland et al. (2004); De Leeuw \& Ekkel (2003) e Durrell et al. (2003). 
Tabela 2. Etograma comportamental para matrizes gestantes alojadas em baias individuais e coletivas

\begin{tabular}{|c|c|}
\hline & Descrição \\
\hline \multicolumn{2}{|l|}{ Atividade } \\
\hline Inativo 1,2 & $\begin{array}{l}\text { Animal totalmente deitado (ventral e/ou lateralmente) com os } \\
\text { olhos fechados e sem nenhuma atividade oral. }\end{array}$ \\
\hline Inativo (alerta) ${ }^{1,2}$ & Parado em pé, deitado ou sentado com os olhos abertos. \\
\hline Cheirar ${ }^{1,2}$ & Cheirar o piso realizando movimentos circulares. \\
\hline Beber ${ }^{1,2}$ & $\begin{array}{l}\text { Manipular o bebedouro (chupeta) verificando-se consumo de } \\
\text { água. }\end{array}$ \\
\hline \multicolumn{2}{|l|}{ Estereotipia } \\
\hline Movimentar a língua ${ }^{1,2}$ & Aerofagia e mostrar a língua repetitivamente. \\
\hline Lamber ${ }^{1,2}$ & Lambendo o piso, a língua toca o piso. \\
\hline Abrir e fechar a boca ${ }^{1,2}$ & $\begin{array}{l}\text { Abrir e fechar a boca mantendo a mandíbula estirada durante } \\
\text { alguns segundos. }\end{array}$ \\
\hline Morder ${ }^{2}$ & Morder barras da cela de gestação. \\
\hline Beber ${ }^{1,2}$ & Acesso ao bebedouro e/ou chupeta obsessivamente. \\
\hline Esticar o pescoço ${ }^{1,2}$ & Esticar o pescoço e observar o ambiente a sua volta. \\
\hline Fuçar ${ }^{1,2}$ & $\begin{array}{l}\text { Fuçar cocho de alimentação e/ou piso sólido repetidas vezes, } \\
\text { sem que exista alimento. }\end{array}$ \\
\hline \multicolumn{2}{|r|}{ 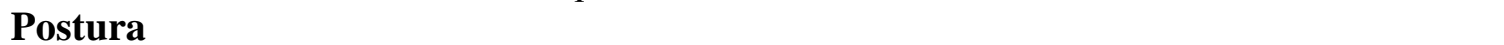 } \\
\hline Deitar na posição ventral ${ }^{1,2}$ & $\begin{array}{l}\text { Apoiar a barriga sobre o piso com todas as pernas debaixo do } \\
\text { corpo. }\end{array}$ \\
\hline Deitar na posição lateral ${ }^{1,2}$ & Deitar de lado com todas as pernas estiradas horizontalmente. \\
\hline Em pé ${ }^{1,2}$ & Corpo apoiado nas quatro pernas (não caminhando). \\
\hline Sentar ${ }^{1,2}$ & $\begin{array}{l}\text { Apoiar sobre os membros dianteiros e sentar sobre os } \\
\text { membros traseiros. }\end{array}$ \\
\hline Ajoelhar ${ }^{1,2}$ & Membros dianteiros dobrados e traseiros estirados na vertical. \\
\hline \multicolumn{2}{|l|}{ Interacão Social } \\
\hline Lambiscar ${ }^{1,2}$ & $\begin{array}{l}\text { Pequenos movimentos de mastigação, enquanto toca outro } \\
\text { animal com a boca. }\end{array}$ \\
\hline Cheirar ${ }^{1,2}$ & $\begin{array}{l}\text { Cheirar outro animal, movimentos circulares fuçando ao } \\
\text { longo do animal. }\end{array}$ \\
\hline Lamber $^{1,2}$ & Lamber outro animal, a língua toca o animal. \\
\hline \multicolumn{2}{|l|}{ Interação agressiva } \\
\hline Empurrar $^{1}$ & $\begin{array}{l}\text { Bater ou empurrar outro animal com a cabeça, mordendo ou } \\
\text { não. }\end{array}$ \\
\hline Morder ${ }^{1,2}$ & morder em uma parte do corpo de outro animal. \\
\hline Brigar $^{1}$ & $\begin{array}{l}\text { Empurrar-se mutuamente com a cabeça, em paralelo ou na } \\
\text { perpendicular, mordendo ou não, em rápidas sucessões. }\end{array}$ \\
\hline Perseguir ${ }^{1}$ & Mover-se rapidamente em perseguição a outro animal. \\
\hline Ameaçar ${ }^{1}$ & $\begin{array}{l}\text { Contato intimidador, cabeça com cabeça, com refugo de um } \\
\text { dos animais. }\end{array}$ \\
\hline
\end{tabular}

(1) baias coletivas; (2) baias individuais 


\subsubsection{Sistema de monitoramento comportamental}

O registro das imagens, para sua posterior análise, foi realizado por meio de 8 microcâmeras coloridas (sistema NTSC) analógicas de 300 linhas horizontais de definição, com sensibilidade mínima de 1 lux, $12 \mathrm{~V}$ de tensão à $180 \mathrm{~mA}$, e lente convergente de 2,45 mm. Esse tipo de câmera tem como característica impedância de saída $75 \Omega$, não havendo processamento digital ou compressão da imagem, portanto, sua transmissão é em tempo real, equivalente a trinta fotos por segundo (Figura 9).
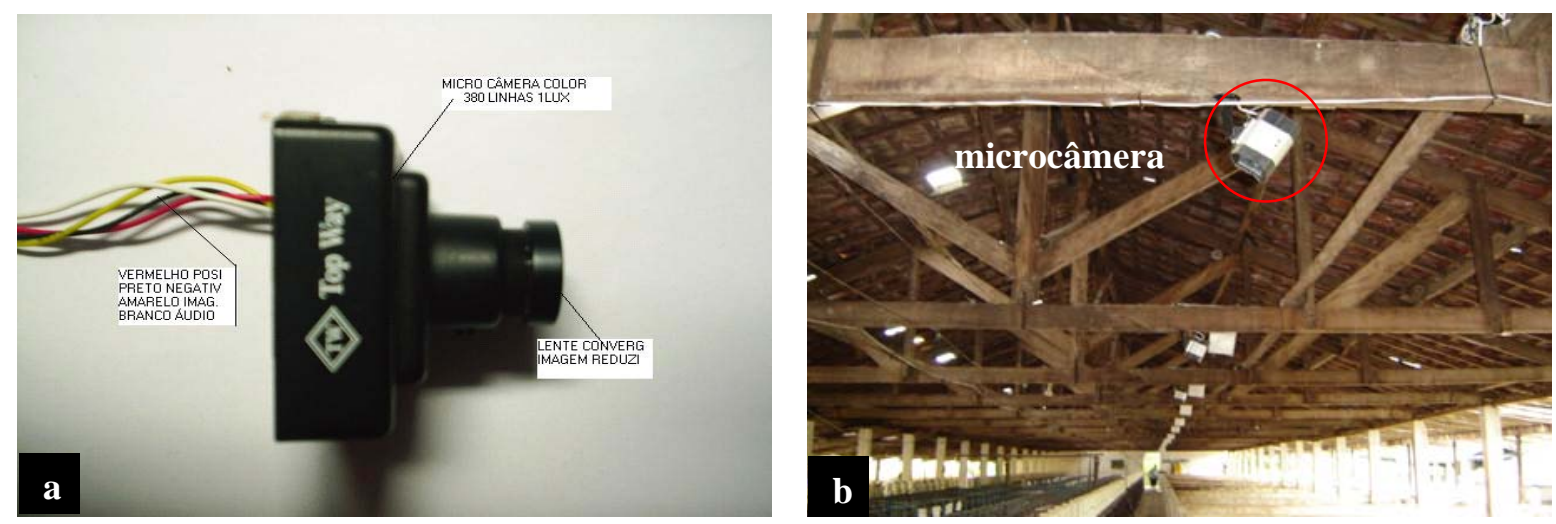

Figura 9 - Visualização da microcâmera utilizada no experimento (a) e instalada no local do estudo (b)

As imagens foram registradas semanalmente, totalizando nove dias de observação, nos horários das 7 às 18 horas, possibilitando gravação contínua das imagens durante todo período de observação, sendo gerenciadas pelo software "TOPWAY", armazenando as informações num banco de dados para posterior análise. No entanto, para critério de análise das imagens, foram estabelecidos horários de observação, das 8 às 9 , das 12 às 13 e das 16 às 17 horas, totalizando três horas de observação para os dias selecionados em intervalos de 4 minutos entre as composições de imagens, de acordo com observações prévias que caracterizaram extensos períodos de inatividade dos animais, sem que houvesse variação comportamental que pudesse ser identificada, na qual foram selecionados aleatoriamente seis animais de cada tratamento (Rudkin \& Stewart, 2003). As matrizes foram devidamente identificadas com numeração no dorso, 
variando de 1 a 12 para os seus respectivos tratamentos, o que possibilitou a individualização de cada animal no momento da análise das imagens (Figura 10).

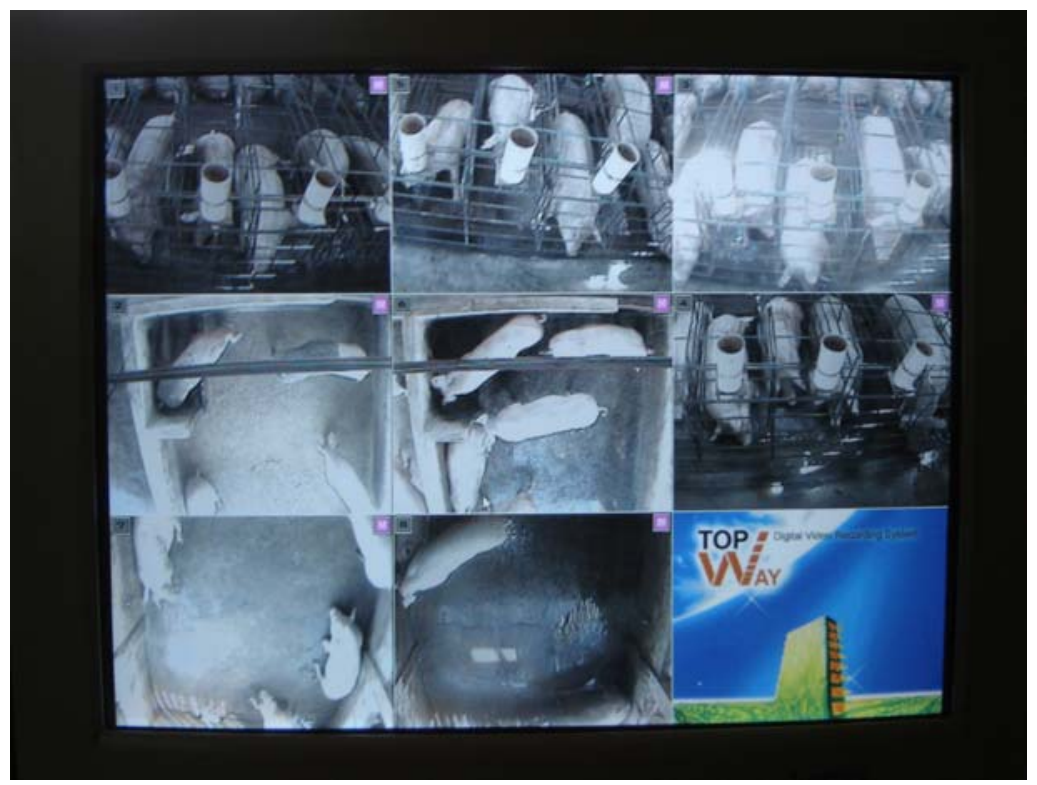

Figura 10 - Visualização da tela do software de captura das imagens

Todas as microcâmeras foram conectadas a uma placa de captura de imagem que permite que um ou mais pulsos elétricos enviados pelas câmeras sejam processados, convertidos digitalmente, comprimidos (JPEG, JPEG+, JPEG+4 etc) e armazenados no disco rígido do PC. Ao mesmo tempo, observa-se que esses pulsos convertidos analogicamente em imagens apresentam um pequeno atraso no domínio de tempo (delay). Este atraso é devido ao tempo de processamento e conversão digital.

A placa de captura de imagem utilizada neste experimento tem as seguintes características: entrada para 16 câmeras, processamento máximo de 30 frames por segundo em NTSC ou 25 frames por segundo em PAL, permitindo um processamento de aproximadamente 4 frames por segundo. Sabe-se que, para a composição de uma imagem em tempo real, é necessário algo próximo a 30 frames, dessa forma nota-se uma segmentação da imagem observada.

Todo cabeamento foi realizado com a utilização de cabo CI 8/50AWG, contendo em seu interior uma quantidade de 8 pares referentes às 8 câmeras, isto é, um par por 
câmera com impedância característica que varia de fabricante para fabricante, algo que é compensado pelos conversores ativos de impedância (booster), sendo assim um fator não crítico na instalação, permitindo derivações ao longo de seu percurso, o que não acontece em cabos coaxiais em longas distâncias. Esses cabos coaxiais seccionados podem sofrer um ataque de ondas eletromagnéticas, principalmente de rádio-freqüência, comportando-se como antena, agindo como receptor/demodulador, ocasionando interferências no sinal transmitido pela câmera em cabo coaxial. A utilização dos cabos trançados e dos conversores ativos de impedância, em substituição ao cabo coaxial, possibilitou uma economia de $\mathrm{R} \$ 1040,00$, no momento da instalação, considerando-se os valores de $\mathrm{R} \$ 1,50$ o metro do cabo coaxial e de $\mathrm{R} \$ 0,20$ o metro do cabo trançado, sabendo-se que foram utilizados $800 \mathrm{~m}$ no cabeamento das câmeras.

Fez-se uso de um nobreak com estabilizador de tensão, a fim de se amenizar os efeitos dos transitórios ou poluição elétrica na rede, promovendo a regulação de tensão em termos satisfatórios dentro de uma tolerância das especificações dos equipamentos eletrônicos. Essa eficiência só foi alcançada pelo fato do estabilizador de tensão do nobreak ter a referência zero volts em um de seus terminais (aterramento). Isso promoveu "escoamento" do excesso ou a falta de tensão nos terminais (fase/neutro ou fase/fase), quando necessário. Desta forma, os finais da linha de transmissão foram aterradas, permitindo eliminar os ruídos no sinal de vídeo, garantindo o bom funcionamento dos equipamentos.

\subsubsection{Variáveis fisiológicas e índices zootécnicos}

A temperatura retal e a taxa respiratória das matrizes foram registradas semanalmente, às 9, 12 e 17 horas, caracterizando as respostas fisiológicas nos períodos de baixa e alta radiação. As medidas de temperatura foram tomadas com auxílio de um termômetro digital, Digi Sense, modelo 8522-10, e a taxa respiratória, por observação visual direta e quantificação dos movimentos por minuto por meio de um cronômetro digital. Os animais foram selecionados para as avaliações de maneira aleatória, perfazendo uma amostragem de seis matrizes em cada um dos tratamentos. 
Todos os índices zootécnicos que compunham o controle experimental foram fornecidos pela própria granja. Por meio do programa de rastreabilidade foi possível localizar cada animal individualmente, bem como seus índices de produção, no setor de gestação e na fase subseqüente, na maternidade.

\subsection{Animais do estudo}

O estudo foi realizado com animais da raça característica da granja (Landrace e Large White) e fêmeas de genética própria da granja, resultante do cruzamento das matrizes avós e machos híbridos comerciais (PIC-412 Agroceres). As matrizes selecionadas eram de mesma ordem de parto, com o objetivo de eliminar fatores de interferência, habilidade materna, número de leitões/leitegada. Foram selecionadas 12 marrãs para observação no sistema de confinamento em baias individuais de gestação (T1) e 12 animais em baias coletivas (T2), divididas em dois grupos de seis animais, totalizando 24 primíparas para comparação dos sistemas de criação, de acordo com representação esquemática (Figura 11). 


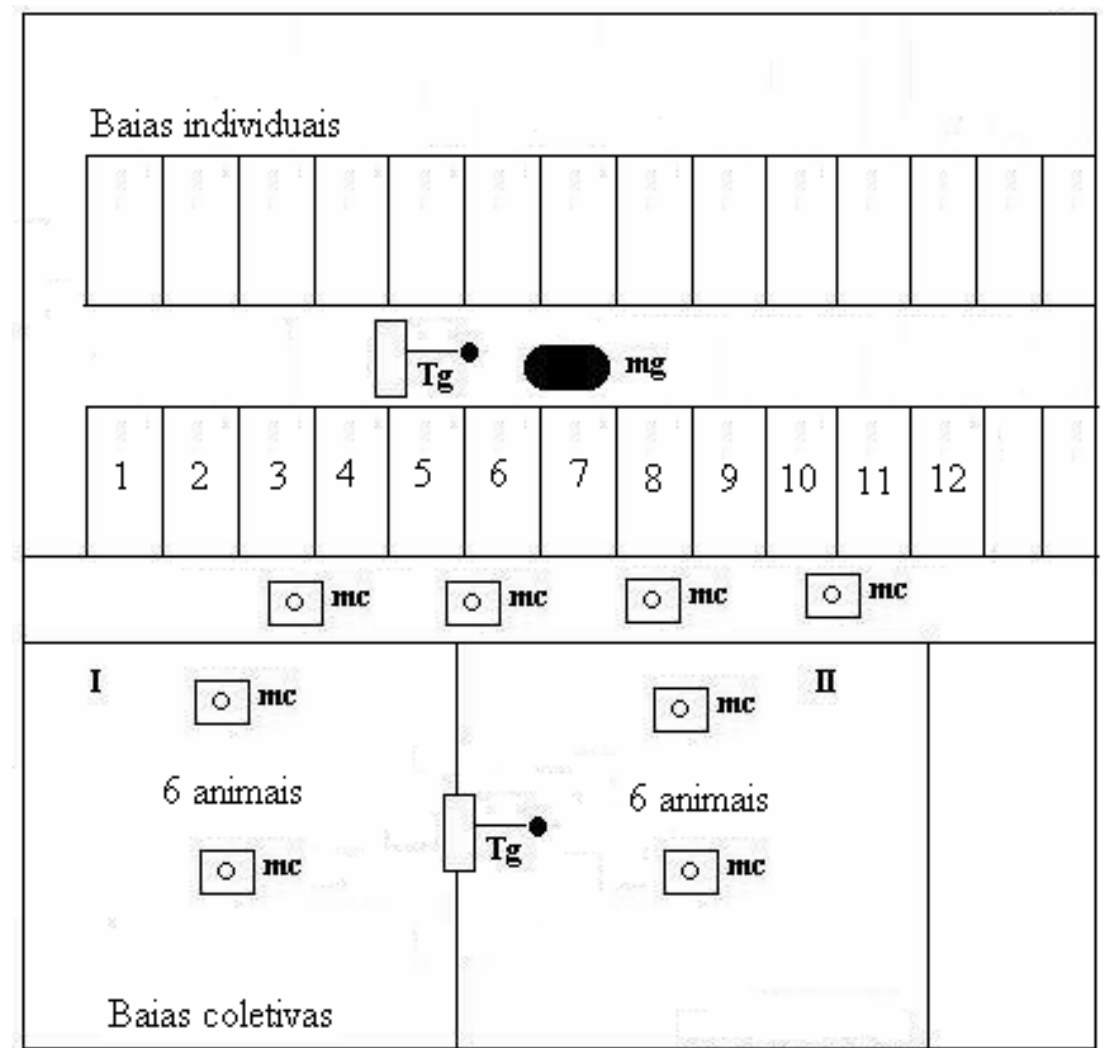

Legenda. Tg (temperatura de globo negro), mc (microcâmera), mg (medidor de gases).

Figura 11 - Esquema geral da distribuição das matrizes em seus respectivos tratamentos

\subsubsection{Manejo dos Animais}

As fêmeas foram cobertas a partir dos 6 meses de idade $( \pm 130 \mathrm{~kg})$, alojadas em grupo até a detecção de cio, quando foram recolhidas e inseminadas em baias individuais, permanecendo nas mesmas, durante um período de 45 dias e posteriormente distribuídas de forma aleatória nos respectivos tratamentos.

Uma ração à base de milho e sorgo, capaz de fornecer $3.250 \mathrm{kcal} \mathrm{EM/dia} \mathrm{(Tabela}$ 3), formulada segundo recomendações do NRC (1998) e distribuída na base de 2,0 $\mathrm{kg} / \mathrm{dia}$ do 0 aos 30 dias; 2,2 kg/dia dos 30 aos 85 dias; 3,0 kg/dia dos 85 aos 110 e 2,0 $\mathrm{kg} /$ dia dos 110 aos 114 dias de gestação, fornecida uma única vez ao dia, às 7 horas. 
Tabela 3. Composição centesimal da ração basal

\begin{tabular}{lr}
\hline Ingrediente (\%) & Ração Basal \\
\hline Sorgo 9,0\% & 25,00 \\
Milho 8,0\% & 24,35 \\
Farelo de soja 45/80 & 20,78 \\
Farelo de arroz gordo & 15,00 \\
Polpa cítrica & 8,00 \\
Levedura de cana 37 & 3,00 \\
Óleo degomado de S & 1,26 \\
Calcário 37\% & 1,20 \\
Fosfato bicálcico Serrana 23 & 0,48 \\
Sal comum & 0,45 \\
Rovimix suíno reprodução & 0,16 \\
Roligomix suíno & 0,15 \\
Availa ferro 6\% & 0,07 \\
Availa zinco 10\% & 0,04 \\
Ronozyme P 5000 & 0,02 \\
L-Treonina & 0,01 \\
DL-Metionina & 0,01 \\
Total & 100,00 \\
Composição calculada & \\
Proteína bruta (\%) & 17,40 \\
Lisina (\%) & 0,89 \\
E.M. (kcal/kg) & 3250 \\
Ca (\%) & 0,87 \\
P (\%) & 0,74 \\
\hline Fonte: Granja Querência
\end{tabular}

Fonte: Granja Querência

\subsection{Aplicação de sistemas inteligentes disponíveis para o estudo de padrões de conforto e predição dos índices zootécnicos}

\subsubsection{Lógica Fuzzy}

Por meio da lógica fuzzy, pretende-se dar um tratamento matemático às variáveis de cunho subjetivo e "nebuloso", portanto, considera-se que, por essas características, a metodologia proposta poderá consistir em uma ferramenta valiosa para ser usada no condicionamento de ambientes de criação para matrizes suínas. Para tanto, foi utilizado o Fuzzy Logic Toolbox do MATLAB ${ }^{\circledR} 6.0$. 
O uso da lógica fuzzy na avaliação do conforto animal permite que sejam analisadas conjuntamente variáveis quantitativas (entradas) e qualitativas (saídas), possibilitando que se obtenha o dinamismo necessário.

Para todo sistema foi adotado o método de mensuração qualitativa, tendo-se em vista manter uma avaliação sistemática entre oferta e demanda do ambiente. A escolha de uma mensuração de tipo qualitativa não determina a modalidade de mensuração, portanto utilizou-se um critério em uma escala de mais de duas modalidades, sobre as quais foram definidas as variáveis lingüísticas que configuram uma demanda e uma oferta em vários níveis qualitativos.

Desta forma, foram consideradas as classificações da condição do sistema de criação em: muito bom (A), bom (B), regular (C) e ruim (D). Em seguida, construiu-se a matriz demanda (variáveis dependentes) em que a classificação feita anteriormente foi substituída por um critério de pesos, sabendo-se que os valores de cada afirmação pertencem a um intervalo de 0 a 1 , onde o valor 1 corresponde a $100 \%$ de veracidade da afirmação. Desta maneira foi possível manipular uma simulação com uma maior flexibilidade, visto que a partir dos pesos fornecidos pelo especialista (baseados na literatura) podem-se obter resultados mais próximos da realidade em relação à sensação de conforto para as matrizes em fase de gestação.

Como passo seguinte, foi definida a matriz oferta, caracterizando as variáveis independentes (variáveis meteorológicas, ambientais, fisiológicas e comportamentais) por termos lingüísticos apropriados (muito alto, alto, médio, baixo e muito baixo) que fornecem a indicação da existência ou ausência de uma condição em um ambiente elementar. A definição da existência é bastante rígida, ou seja, pode-se definir uma condição como favorável se esse fator tem disponibilidade (oferta), igual ou acima de um nível prefixado. A base do desenvolvimento do sistema é o confronto entre a demanda e a oferta dos ambientes de criação através do produto das matrizes, que indica, para cada situação, aqueles ambientes elementares mais favoráveis.

As variáveis de entrada para os dados meteorológicos constituem intervalos de temperatura $\left({ }^{\circ} \mathrm{C}\right)$ e umidade relativa do ar $(\%)$, de acordo com as condições de conforto para matrizes gestantes. Todas as classificações foram desenvolvidas de acordo com as 
condições limites verificadas no estudo e com base nos trabalhos de Esmay, (1982); Hahn, (1987); Noblet, et al. (1989); Pomar et al. (1991); Nienaber et al. (1996), como consta na Tabela 4.

Tabela 4. Classificação do estado de conforto térmico como função da temperatura $\left({ }^{\circ} \mathrm{C}\right)$ e umidade relativa do ar $(\%)$

\begin{tabular}{lccccc}
\hline UR\% & \multicolumn{5}{c}{ Temperatura $\left({ }^{\circ} \mathrm{C}\right)$} \\
\hline$<70$ & $<12$ & $12-21$ & $21-24$ & $24-28$ & $>29$ \\
$70-80$ & muito bom & muito bom & bom & regular & ruim \\
$>80$ & bom & muito bom & bom & regular & ruim \\
\hline
\end{tabular}

Para as variáveis temperatura $\left({ }^{\circ} \mathrm{C}\right)$ e amônia $(\mathrm{ppm})$ a definição das variáveis lingüísticas caracterizada pela sensação de conforto das matrizes foi baseada nos resultados encontrados no estudo e em trabalhos desenvolvidos por Esmay (1982); Pomar et al. (1991); CIGR (1994); Nienaber et al. (1996); e Donham (1999), conforme apresentado na Tabela 5.

Tabela 5. Classificação do estado de conforto térmico como função da temperatura $\left({ }^{\circ} \mathrm{C}\right) \mathrm{e}$ a concentração de amônia $\left(\mathrm{NH}_{3}\right)$

\begin{tabular}{lccccc}
\hline $\mathrm{NH}_{3}(\mathrm{ppm})$ & \multicolumn{5}{c}{ Temperatura $\left({ }^{\circ} \mathrm{C}\right)$} \\
\hline \multicolumn{1}{c}{$<15$} & $<15$ & $15-20$ & $20-25$ & $25-30$ & $>30$ \\
$1-5$ & muito bom & muito bom & bom & regular & ruim \\
$5-10$ & muito bom & muito bom & bom & regular & ruim \\
$>10$ & bom & bom & regular & ruim & ruim \\
\hline
\end{tabular}

As variáveis independentes constituem intervalos de temperatura e da taxa respiratória, definindo o termo dependente pela sensação de conforto das matrizes. As classificações foram formuladas pela organização da base de dados geradas e apoiadas na literatura, Oliveira et al. (1997); Tavares et al. (1999); Hannas et al. (1999) com o objetivo de obter as informações da Tabela 6. 
Tabela 6. Classificação do estado de conforto térmico como função da temperatura $\left({ }^{\circ} \mathrm{C}\right)$ e a taxa respiratória (mov. $\mathrm{min}^{-1}$ )

\begin{tabular}{|c|c|c|c|c|c|}
\hline $\begin{array}{c}\text { Taxa } \\
\text { respiratória } \\
\left(\text { mov. } \text { min }^{-1}\right)\end{array}$ & \multicolumn{5}{|c|}{ Temperatura $\left({ }^{\circ} \mathrm{C}\right)$} \\
\hline & $<15$ & $15-20$ & $20-25$ & $25-30$ & $>30$ \\
\hline$<30$ & muito bom & muito bom & bom & regular & ruim \\
\hline $30-50$ & muito bom & muito bom & bom & ruim & ruim \\
\hline $50-70$ & regular & bom & regular & ruim & ruim \\
\hline$>70$ & ruim & regular & ruim & ruim & ruim \\
\hline
\end{tabular}

Em relação às variáveis descritas na pesquisa, utilizaram-se a entalpia $\left(\mathrm{kJ} . \mathrm{kg}^{-1}\right)$ e inatividade animal como base para mais uma simulação. De acordo com os trabalhos de Stolba et al. (1983); Cronin \& Wiepkema (1984); Silva, (1999); Schouten et al. (2000) definiram-se as classificações que integraram sua base de regra (Tabela 7).

Tabela 7. Classificação do estado de conforto térmico como função da entalpia e a inatividade animal

\begin{tabular}{lcccc}
\hline Inatividade (\%) & \multicolumn{4}{c}{ Entalpia $\left(\mathrm{kJ}^{\left.-\mathrm{kg}^{-1}\right)}\right.$} \\
\hline & $<60$ & $60-70$ & $70-80$ & $>80$ \\
$<15$ & muito bom & muito bom & bom & regular \\
$15-45$ & bom & bom & regular & ruim \\
$45-65$ & regular & regular & ruim & ruim \\
$>65$ & ruim & ruim & ruim & ruim \\
\hline
\end{tabular}

O método de inferência ou fuzzificação adotado foi o método de Mamdani, que combina os graus de pertinência de cada um dos valores de entrada, por meio do operador mínimo e agrega as regras pelo operador máximo. Dado um conjunto de valores para a variável entrada, o sistema obtém um conjunto nebuloso, como o valor da variável de controle. Este conjunto nebuloso representa uma ordenação no conjunto de ações de controle aceitáveis naquele momento. Finalmente, uma ação de controle global foi selecionada dentre aquelas aceitáveis em um processo conhecido como defuzificação (Sandri \& Correa, 1999). 
As transformações dos resultados fuzzy em um valor numérico foram obtidas pela defuzificação, pelo método do centro de área (COA) em que o centro de saída é o centro de gravidade da função de distribuição de possibilidade da ação de controle (Mamdani, 1976; Amendola, et al., 2004).

As análises desenvolvidas neste trabalho poderiam ser implementadas através de outros métodos que não a lógica fuzzy, principalmente se forem consideradas apenas as variáveis temperatura, umidade e os usuais índices de conforto térmico. No entanto, a sua implementação através da lógica fuzzy possibilitou uma expansão pertinente que, além de incluir regras de interação mais sofisticadas entre essas variáveis, permitiu a inclusão de novas variáveis de análise como concentração de gases e comportamento animal visando à determinação do estado de conforto e bem-estar das matrizes suínas.

\subsubsection{Redes Neurais Artificiais (RNAs)}

Por meio da utilização da RNA, procedeu-se a um tratamento físico, estatístico e matemático às variáveis estudadas. Portanto, considerou-se que, por essas características, a metodologia proposta consistiu em uma ferramenta valiosa para ser usada no condicionamento de ambientes de criação para matrizes suínas.

As variáveis que integraram a construção da rede foram: temperatura e taxa respiratória (variáveis de entrada), utilizando-se a base de dados obtidos no período experimental; peso no nascimento dos leitões e número de leitões mumificados (variáveis de saída) registradas na maternidade, referentes aos animais submetidos aos tratamentos estudados.

Após a seleção das variáveis, todos os dados foram normalizados para incorporação no processo de treinamento da rede. O modelo utilizado neste trabalho, para desenvolvimento da rede neural, foi o algoritmo backpropagation, criado por Rumelhart, Hinton \& Williams em 1986 (McClelland, 1988; Zurada, 1992; Haykin, 2001) a partir da generalização da regra de aprendizado Widrow-Hoff, que fora introduzida por Bernard Widrow \& Marcian Hoff em 1960-1962 para redes do tipo feedfoward perceptron. 
A regra de aprendizado Widrow-Hoff também é conhecida como Regra Delta LMS (minimização do erro médio quadrático) que ajusta os pesos das conexões entre os neurônios da rede de acordo com o erro. Esta regra tem como objetivo encontrar um conjunto de pesos e polarizações que minimizem a função erro.

$$
E=\frac{1}{2} \sum_{p=1}^{R} \sum_{i=1}^{S}\left(y_{p, i}-\hat{y}_{p, i}\right)^{2}
$$

em que $R$ = número de padrões ou vetores de entrada; $S$ = número de neurônios de saída - dimensão do vetor de saída; $y_{p, i}=$ saída desejada no i-ésimo neurônio, quando o p-ésimo padrão é apresentado; $\hat{y}_{p, i}=$ saída obtida pela rede no i-ésimo neurônio, quando o p-ésimo padrão é apresentado.

A alteração dos pesos $W_{i, j}$ da regra de Widrow-Hoff é calculada da seguinte maneira:

$$
\Delta W_{i, j}=-\eta \frac{\partial E}{\partial W_{i, j}}
$$

em que, $\eta=$ parâmetro da taxa de aprendizado e $\frac{\partial E}{\partial W_{i, j}}$ é a derivada parcial do erro em relação ao peso da respectiva conexão (gradiente). A principal restrição na minimização do erro no sentido do gradiente descendente é que a função de transferência do neurônio tem que ser monotônica e diferenciável em qualquer ponto.

$\mathrm{O}$ algoritmo backpropagation (BP) refere-se a uma regra de aprendizagem que consiste no ajuste dos pesos e polarizações da rede, através da retropropagação do erro encontrado na saída. A minimização é conseguida realizando-se continuamente, a cada interação, a atualização dos pesos e das polarizações da rede no sentido oposto ao do gradiente da função no ponto corrente, quer dizer, proporcionalmente ao negativo da derivada do erro quadrático em relação aos pesos correntes. Trata-se, portanto de um 
algoritmo de treinamento supervisionado, determinístico, de computação local, e que implementa o método do gradiente descendente na soma dos quadrados dos erros.

A topologia da arquitetura da rede utilizada foi formada por uma camada de entrada, uma escondida (intermediária) de neurônios não-lineares e uma camada de saída de neurônios com função de transferência tangente sigmoidal (Figura 12). Devido à grande difusão da arquitetura da rede a que esta regra de aprendizagem se aplica, é comum referir-se a ela com o nome da própria regra de aprendizagem, rede BP.

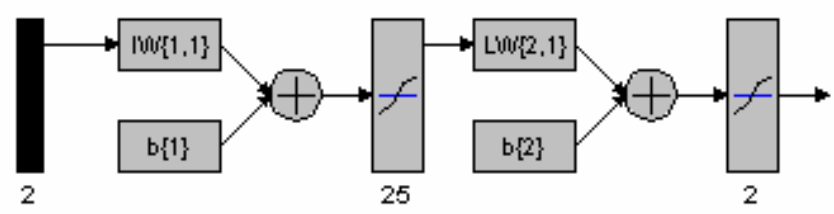

Figura 12 - Arquitetura da rede empregada no treinamento

O algoritmo BP para um treinamento incremental pode ser descrito pelos seguintes passos:

- Passo 1 - inicializar os pesos, as polarizações e os demais parâmetros de treinamento;

- Passo 2 - apresentar à rede um padrão de entrada do conjunto de treinamento e computar a sua saída;

- Passo 3 - calcular o erro para os neurônios da camada de saída, subtraindo a saída desejada da saída calculada;

$$
e_{k}=\left(y_{k}-\hat{y_{k}}\right)
$$

em que: $y$ é a saída desejada e ${ }^{y}$ a saída real (saída gerada pela rede).

- Passo 4 - calcular o ajuste nos pesos da camada da saída com a fórmula:

$$
\Delta w_{i}^{o}(k+1)=-\frac{\partial e_{k}^{2}}{\partial w_{i}^{o}(k+1)}=\eta \cdot\left(y_{k}-\hat{y_{k}}\right) \cdot p^{\prime}\left(n e t^{0}(k)\right) \cdot a^{\prime}\left(w_{i}^{o}(k), O_{i}^{1}(k)\right)
$$


em que: $p$ é uma função contínua derivável, tangente hiperbólica, $\eta$ é a taxa de aprendizagem, net é o estado de ativação e $O_{i}^{1}$ a entrada.

- Passo 5 - retropropagar o erro para as camadas escondidas. Como não existe uma saída desejada para os neurônios das camadas escondidas, deve-se calcular o erro destes a partir do erro dos neurônios pertencentes à camada de saída e das conexões que os interligam. Tem-se, assim, a seguinte equação para calcular o ajuste dos pesos para a primeira camada escondida mais próxima à saída.

$$
\begin{aligned}
\Delta w_{j, i}^{1}(k+1)=-\frac{\partial e_{k}^{2}}{\partial w_{j, i}^{1}(k+1)}= & \eta \cdot\left(y_{k}-\hat{y_{k}}\right) p^{\prime}\left(n e t^{o}\right) \cdot \frac{\partial a}{\partial O_{j}^{1}(k)}\left(w_{j}^{o}(k), O_{j}^{1}(k)\right) \cdot p^{\prime}\left(n e t_{j}^{1}\right) . \\
& \cdot \frac{\partial a}{\partial w_{j, i}^{1}(k)}\left(w_{j, i}^{1}(k), x_{i}(k)\right)
\end{aligned}
$$

- Passo 6 - calcular o erro acumulado da rede. Nesta etapa, deve ser verificado se o erro total sobre todos os padrões de entrada pode ser considerado desprezível, isto é, se caiu abaixo de um limiar de aceitação. Se assim for o caso, o algoritmo deve parar, caso contrário, deve-se voltar ao passo 2.

A configuração da rede BP de 3 camadas (1 de entrada, 1 escondida e 1 de saída) utilizada na aproximação das variáveis temperatura e taxa respiratória e os índices zootécnicos, peso no nascimento dos leitões e mumificados, em que a matriz de entrada foi de 27 × 2, a saber, 27 observações com 2 variáveis e a matriz de saída é 27 x 2 . Segundo um critério heurístico, escolheu-se a seguinte topologia: 25 neurônios para a camada escondida e 2 neurônios para a camada de saída (Tabela 8).

Tabela 8. Parâmetros de treinamento utilizados para o algoritmo backpropagation

\begin{tabular}{lc}
\hline \multicolumn{1}{c}{ Parâmetros } & Valor \\
\hline Taxa de aprendizagem & 0,1 \\
Erro & 0,005 \\
Neurônio na camada oculta & 25 \\
Função de transferência na camada oculta & Tangente sigmoidal \\
Função de transferência na camada de saída & Tangente sigmoidal \\
\hline
\end{tabular}


$\mathrm{Na}$ avaliação do desempenho da rede para o teste e a validação da RNA, utilizou-se um conjunto de dados históricos da granja, sendo que $70 \%$ dos dados selecionados foram utilizados para o teste e $30 \%$ para sua validação.

Para resolução das etapas subseqüentes, utilizou-se o Neural Network Toolbox do Matlab $^{\circledR}$ 6.0, que é um ambiente de desenvolvimento bastante difundido tanto no contexto acadêmico, quanto no âmbito comercial. O Matlab é uma poderosa ferramenta para problemas de cunho matemático, tendo ferramentas gráficas avançadas para análise e visualização de dados. Além disso, possui uma toolbox exclusiva para redes neurais artificiais, isto é, possui um conjunto de funções pré-definidas que são de grande valia para projetos envolvendo redes neurais artificiais.

\subsection{Delineamento Experimental}

O delineamento experimental adotado para análise geral foi em blocos casualizados (DBC), adotando-se como tratamentos os sistemas de confinamento em baias de gestação individuais e coletivas, sendo o número de dias estudados no experimento considerados como blocos. As variáveis meteorológicas, ambientais e os parâmetros fisiológicos foram analisados, adotando o DBC para análise geral, e o teste de Tukey $(\mathrm{P}<0,01)$ para a comparação entre as médias. Foram realizadas análises horárias durante o período do estudo (67 dias consecutivos), englobando a fase de gestação na qual os animais permaneceram em seus respectivos tratamentos, sendo que os dados meteorológicos, ambientais, índices de conforto calculados e os parâmetros fisiológicos registrados obedeceram ao seguinte modelo matemático:

$$
Y i j=\mu+\tau i+\beta j+\varepsilon i j
$$

Onde:

$\mu=$ constante inerente a todas as observações;

$\tau \mathrm{i}=$ efeito do i-ésimo tratamento;

$\beta \mathrm{j}=$ efeito do $\mathrm{j}$-ésimo bloco;

$\varepsilon \mathrm{ij}=$ erro experimental, $\varepsilon \mathrm{ij} \sim \mathrm{N}\left(0, \sigma^{2}\right)$. 
Para os dados referentes às variáveis comportamentais, foi realizada uma análise de freqüência, adotando-se o programa estatístico Statistical Analysis System (SAS, 1992).

Para análise dos índices zootécnicos, adotou-se o delineamento inteiramente casualizado (DIC) com dois tratamentos e 12 repetições, utilizando-se o teste de Tukey para comparação entre as médias. 


\section{RESULTADOS E DISCUSSÃO}

\subsection{Análise bioclimática}

\subsubsection{Variáveis meteorológicas e índices de conforto}

A comparação entre tratamentos e o ambiente externo, apresentados na Tabela 9, são os resultados médios diários das variáveis respostas da subdivisão do microambiente estudado (sala de gestação), e seus respectivos sistemas de contenção, baias individuais (T1) e baias coletivas (T2). Verificou-se que os tratamentos apresentaram diferenças significativas para temperatura de bulbo seco (Tbs), quando comparados entre si, verificando-se maior temperatura no $\mathrm{T} 1$, em virtude do maior número de animais alojados (animal. $\mathrm{m}^{-2}$ ) neste sistema de contenção, e pelo aporte de energia gerado pelos animais, o T2 apresentou menor Tbs comparativamente ao $\mathrm{T} 1$, fato este atribuído à própria disposição das baias coletivas que ficavam sujeitas à maior renovação de ar, pois estavam localizadas na face sul da sala de gestação.

Com relação à umidade relativa do ar (UR) e à temperatura de globo negro (Tgn), ambas as variáveis não apresentaram diferenças estatísticas entre tratamentos, no entanto o ambiente externo foi o que apresentou a maior média para a UR, caracterizando a condição de entorno à instalação.

Para o índice de temperatura de globo e umidade (ITGU) os valores médios diários não mostraram diferenças significativas a exemplo das variáveis que integram o modelo Tgn e temperatura de ponto de orvalho (Tpo). Os dados médios para a entalpia (h) apontam diferenças significativas entre tratamentos, verificando-se maior quantidade de energia na parcela de ar referente ao sistema de contenção em baias individuais, apresentando valor próximo àquele registrado no ambiente externo. 
Tabela 9. Valores médios diários das variáveis ambientais para o sistema de confinamento em baias coletivas (T1), baias individuais (T2) e no ambiente externo

\begin{tabular}{lccccc}
\hline & $\operatorname{Tbs}\left({ }^{\circ} \mathrm{C}\right)$ & UR $(\%)$ & $\operatorname{Tgn}\left({ }^{\circ} \mathrm{C}\right)$ & ITGU & h $\left({\left.\mathrm{kJ} \cdot \mathrm{kg}^{-1}\right)}^{-1}\right.$ \\
\hline T1 & $25,47 \mathrm{a}$ & $70,48 \mathrm{~b}$ & $25,20 \mathrm{a}$ & $73,40 \mathrm{a}$ & $63,47 \mathrm{a}$ \\
T2 & $25,03 \mathrm{~b}$ & $70,14 \mathrm{~b}$ & $25,20 \mathrm{a}$ & $73,56 \mathrm{a}$ & $62,02 \mathrm{~b}$ \\
Externo & $24,48 \mathrm{c}$ & $79,65 \mathrm{a}$ & $24,97 \mathrm{a}$ & $73,46 \mathrm{a}$ & $63,51 \mathrm{a}$ \\
\hline
\end{tabular}

Valores médios com letras diferentes, na mesma coluna, diferem estatisticamente pelo Teste de Tukey, $\mathrm{P}<$ 0,01

A Figura 13 evidencia o efeito da temperatura nos diferentes tratamentos, baias coletivas e individuais e no ambiente externo. Nestas condições, verifica-se que o condicionamento térmico no interior da instalação esteve acima da condição recomendada, onde a temperatura ambiente considerada ótima para a matriz varia entre 7 e $23{ }^{\circ} \mathrm{C}$ (Noblet et al., 1989), ficando evidente que a condição de conforto proporcionada aos animais está inadequada, pois verifica-se que no decorrer do período avaliado a temperatura média diária esteve a maior parte do tempo superior aos $23{ }^{\circ} \mathrm{C}$, caracterizando-se como uma situação de alerta a possíveis problemas reprodutivos, principalmente em fêmeas primíparas (Love et al., 1995; Wentz et al., 1997; Bortolozzo et al., 1997; Peltoniemi et al., 1999).

Reforçando a afirmação citada acima, pode-se observar na Figura 13 que, durante o estudo, as temperaturas médias se mantiveram próximas à faixa de conforto dos animais, entre 23 e $24{ }^{\circ} \mathrm{C}$, em apenas $18 \%$ do tempo total de registro para ambos os tratamentos (67 dias).

No entanto, a temperatura se encontra durante todo a fase avaliada, abaixo da temperatura crítica superior (TCS), não atingindo na média valores da ordem de $28{ }^{\circ} \mathrm{C}$ (Mount, 1968; Curtis, 1983; Silva, 1999), promovendo condições inadequadas, em que os animais submetidos a esses ambientes, passariam a sofrer estresse calórico e reflexo direto na manutenção dos processos reprodutivos. 


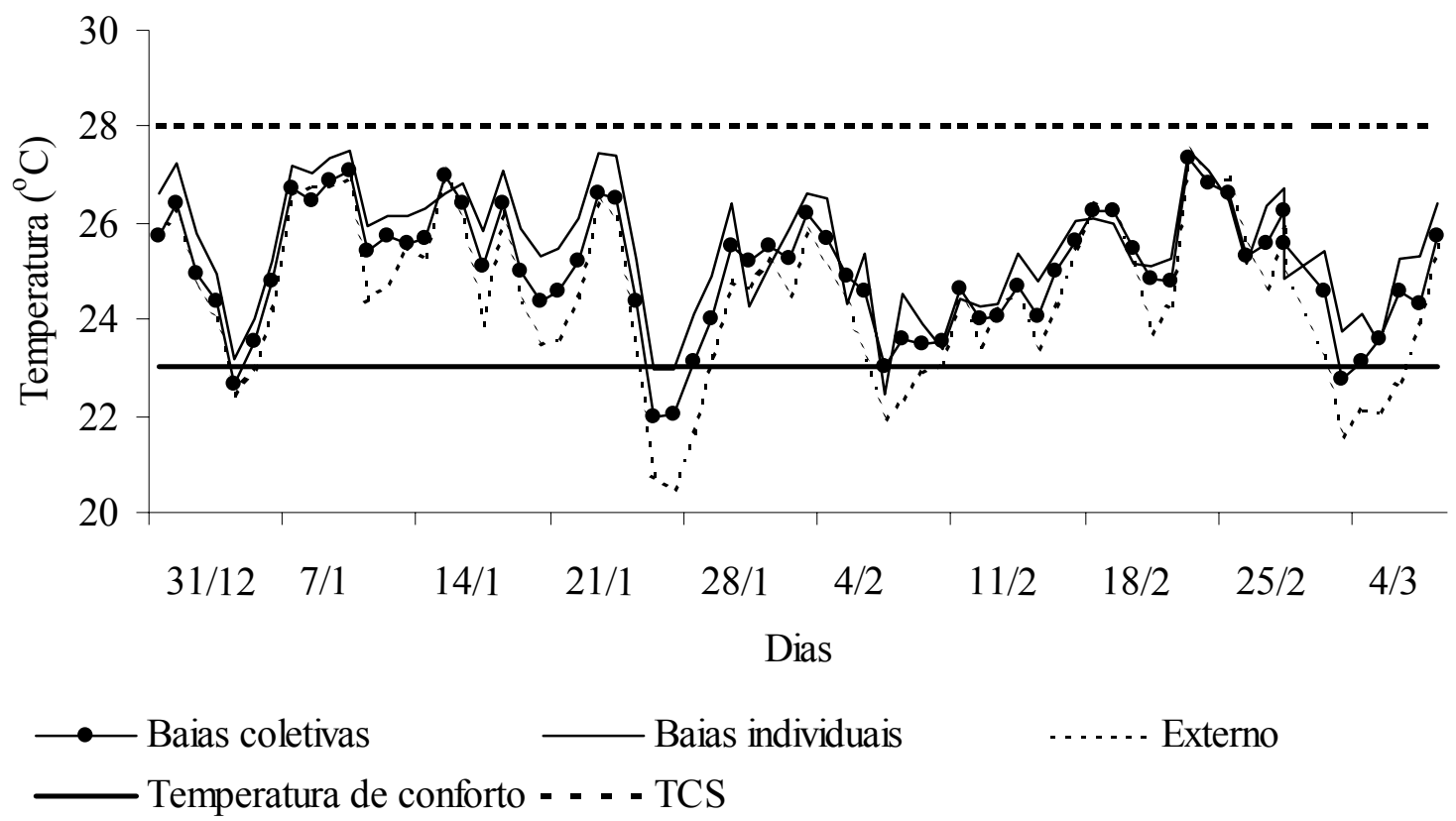

Figura 13 - Variação da temperatura média diária nos diferentes tratamentos na sala de gestação e no ambiente externo

$\mathrm{Na}$ tentativa de evidenciar o efeito do condicionamento térmico das matrizes, foram selecionados os dias críticos do período estudado, que apresentaram maior (25/02) e menor (28/01) valor para entalpia (Silva et al., 1991; Moura, et al., 1997). Desta forma, verifica-se na Figura 14a que entre os horários das 11 às 19 horas a temperatura no interior da sala de gestação esteve acima da TCS para o T2, atingindo um pico de temperatura às 16 horas, em que se registrou um valor da ordem de $32,86{ }^{\circ} \mathrm{C}$.

A intensidade e a duração dos períodos de elevação de temperatura estão associados à dificuldade de fertilização e podem afetar a fixação e a sobrevivência dos conceptos, principalmente na fase inicial de gestação, podendo causar diminuição do fluxo sangüíneo uterino, hipertermia maternal, alteração no metabolismo endócrino das fêmeas, maior taxa de retorno ao cio, menor taxa de parição e tamanho de leitegada (Van der Lende, 1994; Barb et al., 1991; Brandt et al., 1995; Bortolozzo et al., 1997).

No que se refere às baias individuais (T1), observa-se que entre os horários das 11 às 19 horas a temperatura apresentou pequenas oscilações frente à linha da TCS, mostrando-se sempre inferior àquela registrada nas baias coletivas. Esta variação é o 
resultado da modificação do ambiente em virtude do uso de um recurso de resfriamento, já que a instalação dispunha de uma linha de nebulização para os animais alojados nas baias individuais, que era acionada manualmente por um funcionário da granja sempre que a temperatura excedia os $30{ }^{\circ} \mathrm{C}$, reduzindo o efeito do ambiente térmico sobre as matrizes. Segundo Silva (1995), a faixa de temperaturas admissíveis à manutenção da termoneutralidade dos animais, está relacionada com um ambiente térmico ideal, onde a amplitude térmica, ou seja, a diferença entre as temperaturas máxima e mínima do dia, deve-se manter bem estreita, dentro da qual, os animais encontrem perfeitas condições para expressar suas características produtivas e reprodutivas.

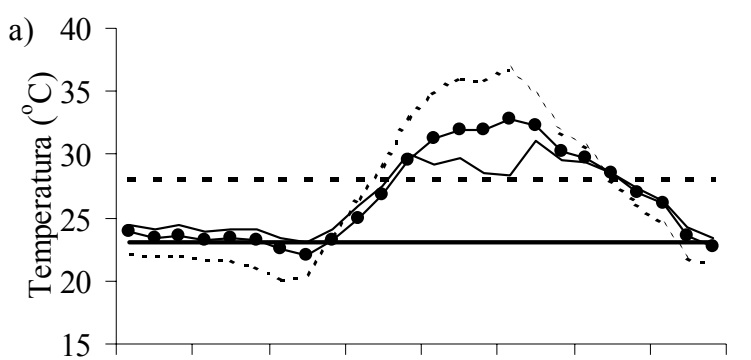

00:00 03:00 06:00 09:00 12:00 15:00 18:00 21:00 Horário

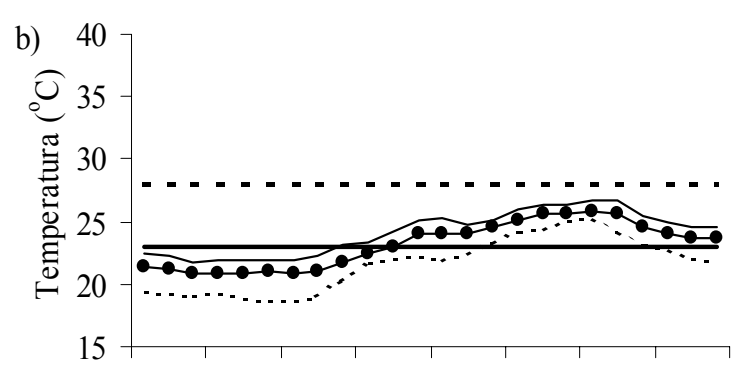

00:00 03:00 06:00 09:00 12:00 15:00 18:00 21:00

Horário

$\longrightarrow$ Baias coletivas _- Baias individuais - - - Externo — Temperatura de conforto - - - TCS

Figura 14 - Variação da temperatura média horária para os dias críticos de maior (a) e menor (b) entalpia nos diferentes tratamentos na sala de gestação e no ambiente externo

Neste contexto, nota-se na Figura 14a que a temperatura máxima registrada no T2 é de $32,86{ }^{\circ} \mathrm{C}$ e a mínima de $22,09{ }^{\circ} \mathrm{C}$, resultando em uma amplitude de $10,70{ }^{\circ} \mathrm{C}$. De maneira análoga, tem-se para o $\mathrm{T} 1$, temperatura máxima de $31,02{ }^{\circ} \mathrm{C}$ e mínima de 23,05 ${ }^{\circ} \mathrm{C}$, gerando uma amplitude de $7,17{ }^{\circ} \mathrm{C}$, destacando-se o $\mathrm{T} 1$ como aquele que melhor se adequa às necessidades dos animais, frente à eficiência do sistema de climatização adotado. 
Para segunda condição, observa-se na Figura 14b que a variação da temperatura no decorrer do dia selecionado (28/01) apresentou valores inferiores para o T2, comparativamente a $\mathrm{T} 1$, evidenciando um melhor condicionamento para as baias coletivas, que se mostraram em média mais próximas da condição de conforto das matrizes. Em geral, para os dois tratamentos, observa-se que ambos mativeram-se dentro da faixa recomendada, entre os valores de 23 e $28{ }^{\circ} \mathrm{C}$. A amplitude térmica registrada para o dia de menor entalpia foi de $4,99{ }^{\circ} \mathrm{C}$ para as baias coletivas e de $4,82{ }^{\circ} \mathrm{C}$ para as individuais, evidenciando sua redução comparativamente ao dia de maior entalpia, promovendo condição mais propícia aos animais.

A variação da umidade relativa, no interior da edificação, não apresentou diferenças significativas entre tratamentos, baias coletivas e individuais, mantendo-se dentro de limites considerados adequados de 55 a $85 \%$, de acordo com Veit \& Troutt (1982). O volume de ar se contrai e/ou expande com a variação da temperatura. Essa variação de volume impõe um limite à quantidade de vapor d'água que pode ser retida pelo volume de ar: quanto maior a temperatura, maior a quantidade saturante de vapor d'água. Nessas condições, a tendência de variação diária da umidade relativa do ar está relacionada ao fato de que a pressão parcial de vapor (ea) varia pouco durante o dia, mas a pressão de saturação de vapor (es) varia exponencialmente com a temperatura do ar. Assim, a UR terá tendência de evolução inversa à da temperatura, verificando-se baixos valores de UR para essa situação (Figura 15). 


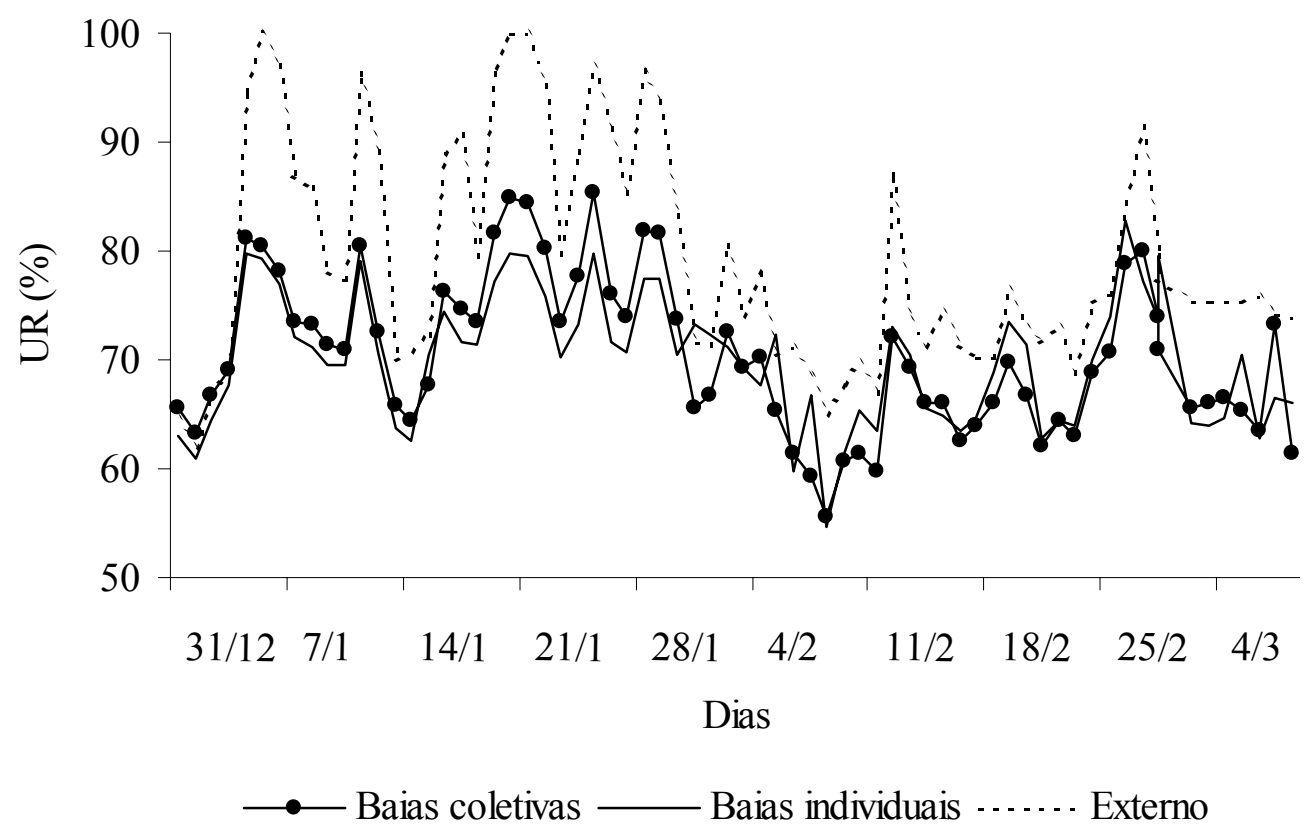

Figura 15 - Variação da umidade relativa média diária nos diferentes tratamentos na sala de gestação e no ambiente externo

Adotando-se o mesmo critério para seleção dos dias críticos utilizado para temperatura, verifica-se na Figura 16a variação de umidade relativa do ar (UR) para os dias 25/02 (a) e 28/01 (b). Respeitando a tendência de evolução inversa entre a temperatura e a umidade, observa-se na Figura 16a que entre os horários de maior temperatura ocorre decréscimo da UR, salvo pela situação de que o tratamento baias individuais possui um sistema de nebulização que promoveu a conversão do calor sensível do ar em calor latente concomitantemente com a redução de temperatura. A Figura 16b caracteriza a variação da UR para os dois tratamentos, e, como neste dia não houve acionamento da nebulização, a UR manteve-se superior para o T2, quando comparado ao T1, porém não significativo. 

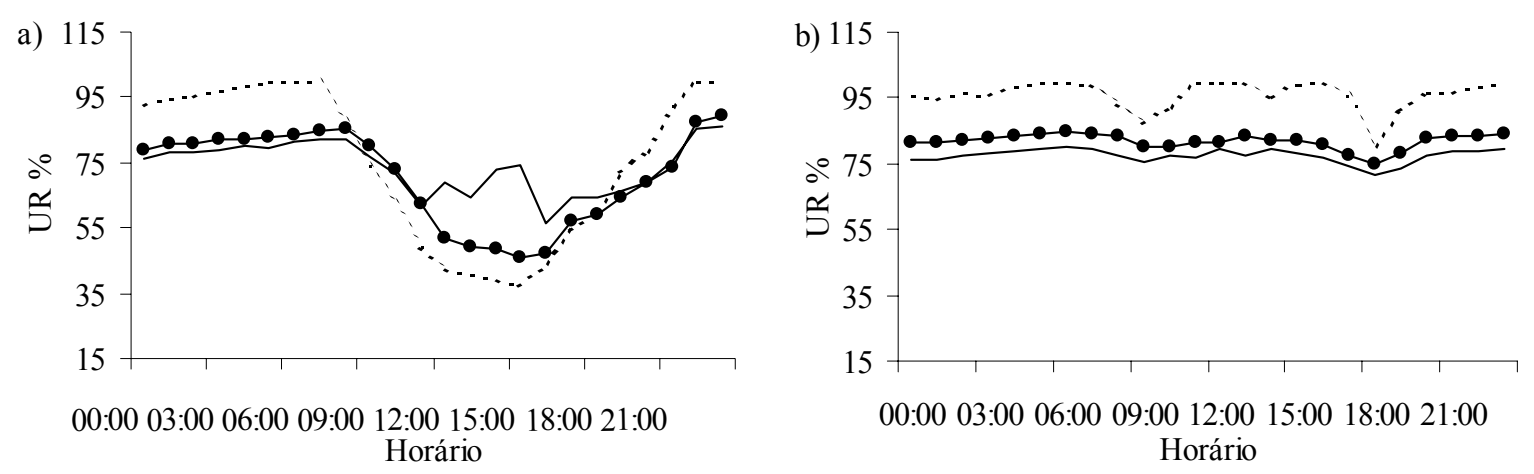

$\longrightarrow$ Baias coletivas — Baias individuais -.-.- Externo

Figura 16 - Variação da umidade relativa média horária para o dia de maior (a) e menor (b) entalpia nos diferentes tratamentos na sala de gestação e no ambiente externo

O desempenho da edificação estudada revela um quadro de desconforto térmico, com temperaturas e umidades excessivas, decorrentes principalmente da deficiência da ventilação. Estes aspectos constituem os principais entraves para alcançar as metas para a otimização econômica do setor, no que tange aos índices zootécnicos. Os problemas gerados não decorrem somente da concepção arquitetônica da construção, mas da ausência da hierarquização das exigências do animal e da determinação dos limites extremos da aceitabilidade ambiental.

Com relação à temperatura de globo negro (Tgn), os valores registrados para os diferentes sistemas de contenção, baias individuais e coletivas, apresentaram variação média diária semelhante entre os tratamentos e o ambiente externo, não apresentando diferenças estatísticas entre si, considerando que o estresse devido ao calor por radiação solar é uma parcela significativa às trocas de calor sensível. Porém, a exposição indireta à radiação solar no interior da instalação, somada à produção de calor pelos animais, manteve um mesmo grau de variação entre o ambiente interno e externo (Figura 17). 


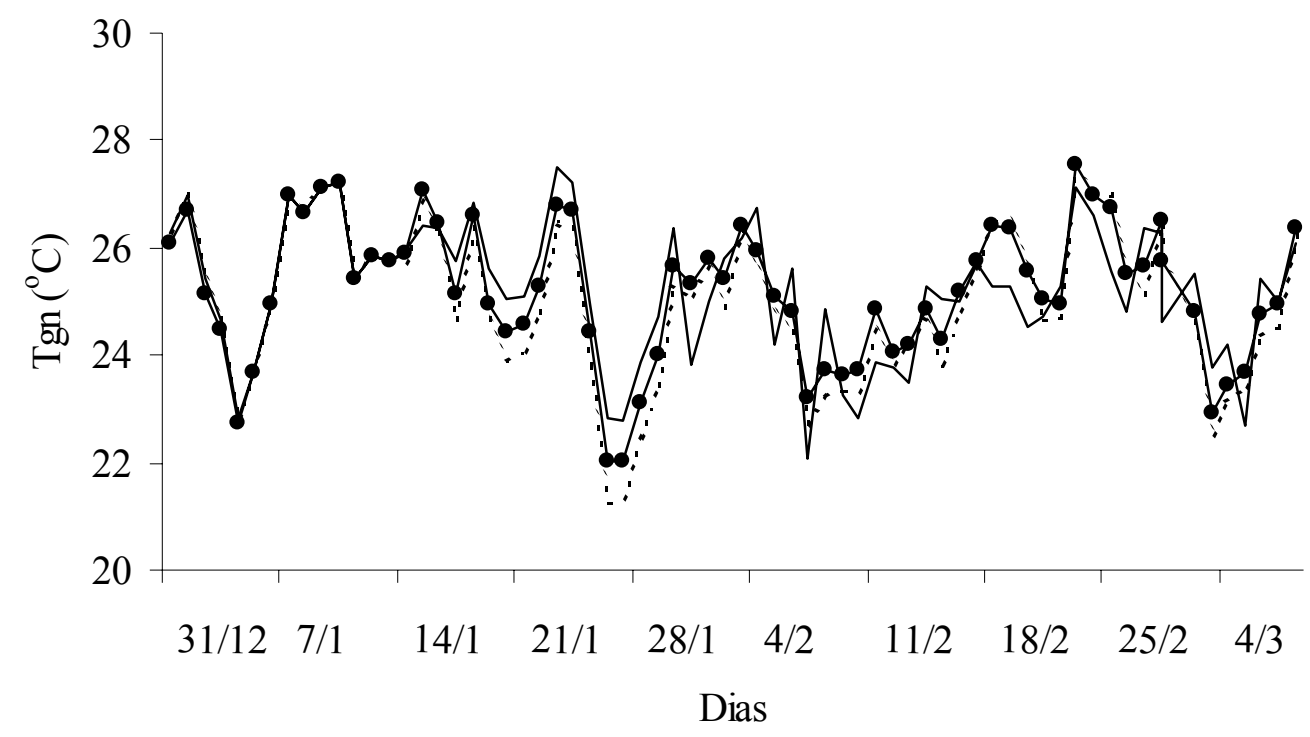

—- Baias coletivas — Baias individuais ...... Externo

Figura 17 - Variação da temperatura de globo negro média diária nos diferentes tratamentos na sala de gestação e no ambiente externo

Sabe-se que a temperatura de globo negro tem como fundamento de utilização a captação da irradiação solar, das superfícies de exposição e dos animais, a partir de uma esfera oca pintada externamente com duas camadas de tinta preta fosca, com o objetivo de maximizar a absorção da radiação, sendo a temperatura fornecida por um sensor colocado no centro interno da esfera, podendo ser considerado um indicativo da sensação térmica dos animais. Na Figura 18a, observa-se um decréscimo na Tgn no T1, resultante do molhamento da superfície externa do globo, devido ao acionamento do sistema de nebulização, o que resultou na redução da temperatura interna registrada pelo sensor, pelo fato da água agir como um moderador da temperatura na superfície da esfera. No entanto, ao se excluir o tempo em que a climatização estava em funcionamento, verifica-se que praticamente não houve variação da Tgn entre os tratamentos, o que também pode ser visualizado na Figura $18 \mathrm{~b}$. 

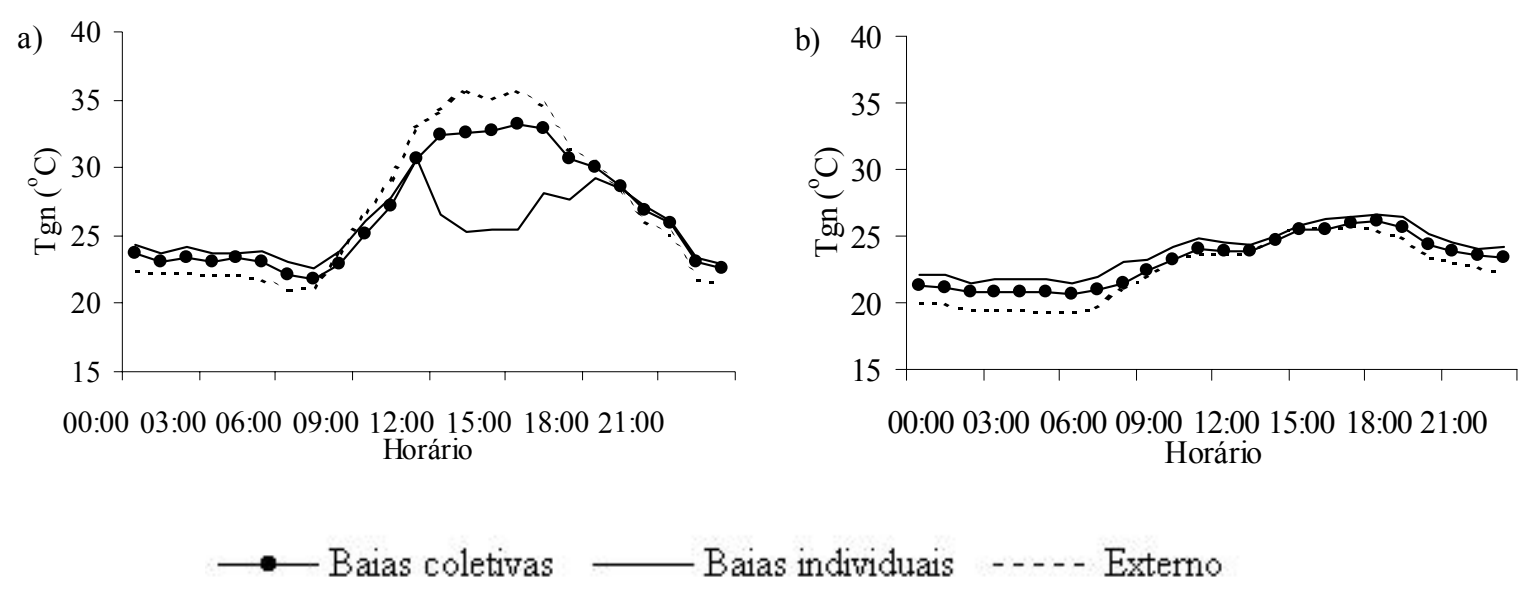

Figura 18 - Variação da temperatura de globo negro média horária para o dia de maior (a) e menor (b) entalpia nos diferentes tratamentos na sala de gestação e no ambiente externo

O índice de temperatura de globo e umidade (ITGU) apresentou valores médios para os tratamentos e para o ambiente externo, que não diferiram estatisticamente. $O$ menor valor de ITGU na sala de gestação foi verificado para o tratamento baias coletivas, e o maior valor encontrado foi para baias individuais, apresentando valores da ordem de 69,62 e 76,59 respectivamente (Figura 19).

Considerando-se o ITGU médio para ambos os tratamentos, baias coletivas e individuais, registraram-se nos mesmos valores de 73,40 e 73,56, respectivamente. Estes dados se mantiveram próximos dos valores recomendados para fase de gestação, não devendo ultrapassar o índice de 72 (Necoechea, 1986). 


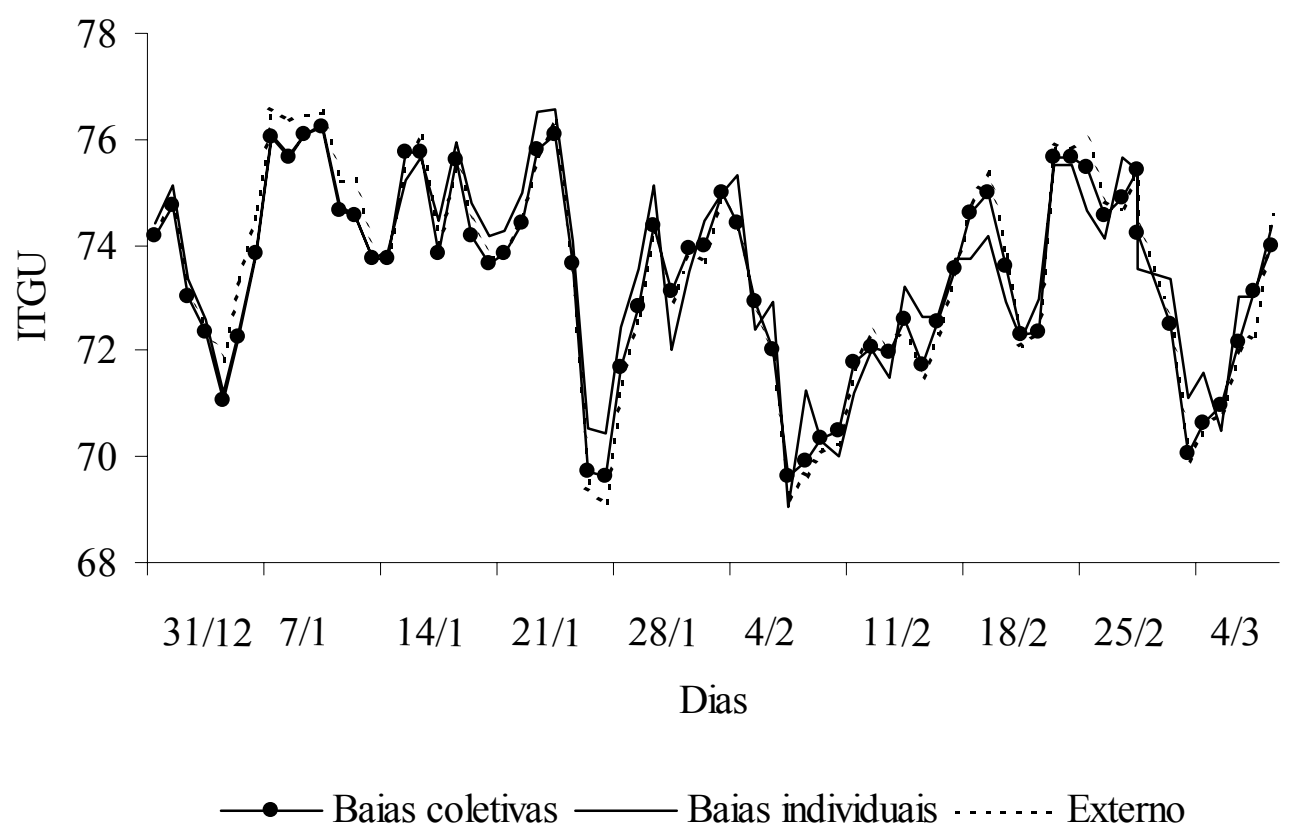

Figura 19 - Variação média diária do índice de temperatura de globo negro e umidade nos diferentes tratamentos na sala de gestação e no ambiente externo

Considerando-se o dia crítico de maior entalpia, pode-se observar na Figura 20a que as variações do ITGU para T1 e T2 apresentaram valores próximos, porém, entre os horários das 11 às 18 horas, o perfil de variação se alterou em função do controle ambiental no T1, resultando na aproximação do ITGU a faixa adequada entre 72 e 76. No T2, o ITGU alcançou valor de pico da ordem de 81,72, considerado estressante para as matrizes em fase de gestação. Para o dia de menor entalpia, verifica-se na Figura 20b que o ITGU não ultrapassou a faixa adequada, mantendo-se sempre abaixo do valor limite de 76, recomendado para os animais desta categoria. 


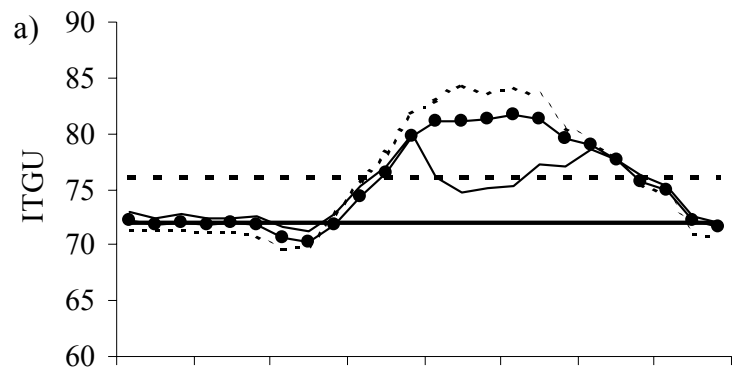

00:00 03:00 06:00 09:00 12:00 15:00 18:00 21:00

Horário

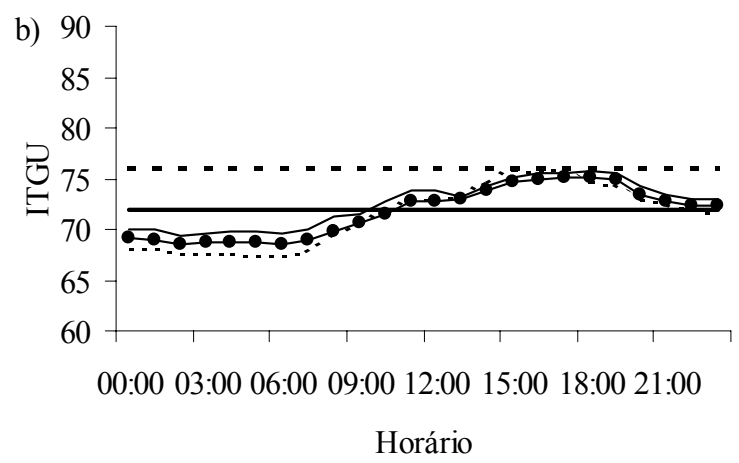

Externo ITGU (conforto) - - . ITGU (Crítico)

Figura 20 - Variação média horária do índice de temperatura de globo negro e umidade para o dia de maior (a) e menor (b) entalpia nos diferentes tratamentos na sala de gestação e no ambiente externo

Os valores médios da entalpia (h) apresentam resultados que apontam diferenças estatísticas entre os tratamentos. O maior valor verificado foi para baias individuais (T1), expressando a quantidade de energia interna da parcela de ar, pontualmente para esta condição no microambiente avaliado, em relação à soma de seus componentes, de uma mistura de ar seco e vapor d'água, levando-se em consideração a Tbs $\left({ }^{\circ} \mathrm{C}\right)$ e a razão de mistura (kg de vapor d'água.kg de ar $\operatorname{seco}^{-1}$ ).

Pode-se verificar, na Figura 21, que a variação entálpica nos tratamentos adotados (T1 e T2), apresentou valor da ordem de 63,47 e 62,02 kJ.kg ${ }^{-1}$ no decorrer do período experimental, não excedendo o valor limite para este índice de $73,80 \mathrm{~kJ} \cdot \mathrm{kg}^{-1}$. As aproximações dos valores de entalpia, recomendada para os animais, foram calculadas com base nas condições de conforto dos animais, considerando-se a temperatura crítica superior de $28{ }^{\circ} \mathrm{C}$, e umidade relativa de $70 \%$, citadas por Silva (1999). 


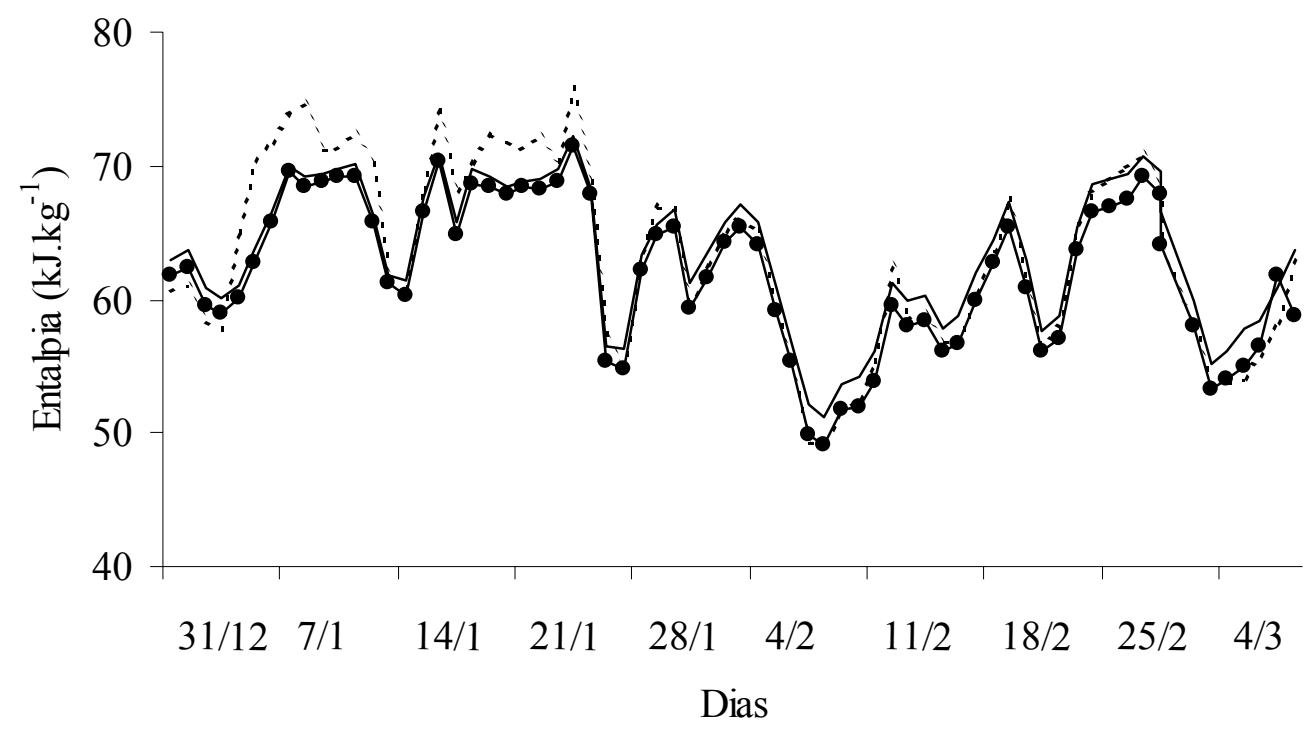

$\longrightarrow$ Baias coletivas $\longrightarrow$ Baias individuais ...... Externo

Figura 21 - Variação média diária da entalpia nos diferentes tratamentos na sala de gestação e no ambiente externo

Com o intuito de ampliar as informações citadas acima, procurou-se representar a condição entálpica até o limite crítico superior, calculada a partir da temperatura de 28 ${ }^{\circ} \mathrm{C}$ e umidade relativa do ar de $70 \%$. Já para o cálculo da entalpia de conforto, adotou-se temperatura de $23{ }^{\circ} \mathrm{C}$ e umidade de 70\%, de acordo com Silva (1999) e Albright (1990). As faixas das variáveis ambientais foram demarcadas nas Figuras 22a e 22b, assim como a variação da entalpia para os dias selecionados na condição interna e externa à instalação.

Verifica-se na Figura 22a, que a variação da entalpia nos tratamentos adotados foi muito similar, estando sempre dentro da faixa estabelecida para o índice, exceto para os horários entre 12 e 17 horas, em que o T1 esteve ligeiramente acima da faixa ideal, valores estimados entre 56,96 e 73,80 kJ.kg ${ }^{-1}$, atingindo um pico de 76,04 $\mathrm{kJ} \mathrm{kg}^{-1}$, em virtude da utilização do nebulizador. Para o dia de menor disponibilidade de energia no ambiente (Figura 22b), observa-se que o índice de entalpia não excedeu a faixa recomendada, para ambos os tratamentos. 


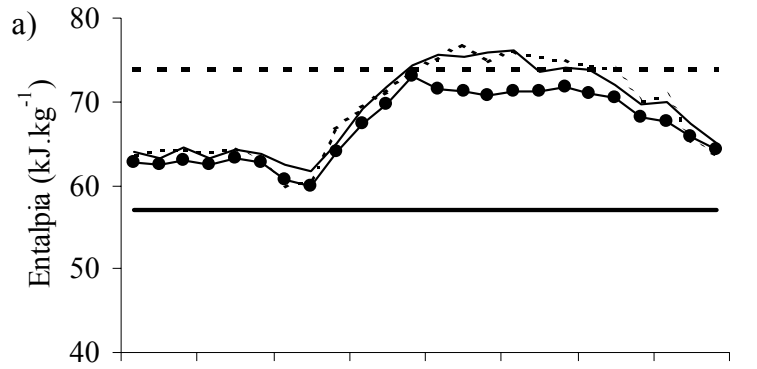

00:00 03:00 06:00 09:00 12:00 15:00 18:00 21:00 Horário

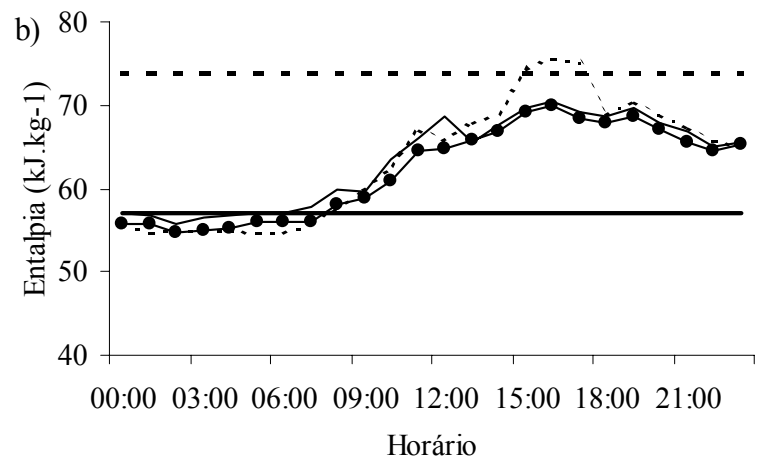

Externo - h (conforto) - - - h (crítico)

Figura 22 - Variação média horária da entalpia para o dia crítico superior (a) e inferior (b) nos diferentes tratamentos na sala de gestação e no ambiente externo

Com base nas variáveis meteorológicas discutidas até o momento, levando-se em consideração o microclima proporcionado aos animais nos diferentes sistemas de confinamento, baias individuais e coletivas, influenciado pelas condições externas à instalação, verifica-se que o desempenho e o layout de distribuição dos animais no sistema de confinamento em baias coletivas permitiram melhor condicionamento térmico natural às matrizes em gestação, considerando-se sua localização no interior da edificação, que potencializava as trocas convectivas de calor por meio da ventilação natural e pelo fato de dispor de maior área por animal. No entanto, o conceito de qualidade do ambiente de produção é amplo e, por sua vez, envolve aspectos relacionados ao microclima, à qualidade do ar, às respostas fisiológicas e produtivas dos animais e a seus reflexos comportamentais.

Isto posto, nota-se que as novas regulamentações da EU, dirigidas ao bem-estar animal, podem envolver aspectos relacionados a alterações no sistema de alojamento de matrizes gestantes, proibindo a utilização de baias individuais para porcas ou marrãs, de maneira a permitir um aumento na área livre destinada aos animais desta categoria, visando à garantia de conforto térmico aos animais. 


\subsubsection{Variáveis ambientais}

\subsubsection{Concentrações de $\mathrm{H}_{2} \mathrm{~S}, \mathrm{CH}_{4}, \mathrm{CO}, \mathrm{O}_{2}$ e $\mathrm{NH}_{3}$}

Os suínos são animais que utilizam o sistema respiratório como importante mecanismo para o resfriamento corporal e conseqüente homeotermia, fator condicionante a sua sobrevivência, portanto quaisquer alterações na temperatura, umidade do ar, ventilação, densidade de criação e, principalmente, limpeza e desinfecção das instalações podem alterar os níveis toleráveis de gases nocivos ao microambiente a que estão expostos, resultando em problemas respiratórios e conseqüentes prejuízos na produtividade.

A degradação biológica do material orgânico (fezes, urina, ração e outros) produz gases tóxicos que podem afetar a saúde e o desempenho dos animais, sendo que os principais agentes poluentes produzidos no interior dos abrigos para suínos são: amônia $\left(\mathrm{NH}_{3}\right)$, sulfeto de hidrogênio $\left(\mathrm{H}_{2} \mathrm{~S}\right)$ e o gás carbônico $\left(\mathrm{CO}_{2}\right)$.

Nos sistemas de criação de suínos, os limites para as concentrações desses gases variam por não existir uma norma no "sens strict" do termo (CIGR, 1994; Larry et al., 1994; Gustafsson, 1999; Perdomo et al., 2001; Nader et al., 2002).

Altas concentrações de $\mathrm{NH}_{3}$, acima de $30 \mathrm{ppm}$, podem ser responsáveis pelo desenvolvimento de inflamações nas vias respiratórias de suínos, culminando em redução do ganho de peso. $\mathrm{O} \mathrm{H}_{2} \mathrm{~S}$ entre 50-200 ppm pode acarretar sintomas como perda de apetite, fotofobia, vômito e diarréia. Valores superiores a $20.000 \mathrm{ppm}$ de $\mathrm{CO}_{2}$ provocam aumento dos batimentos cardíacos, sonolência e dor de cabeça (Perdomo et al., 2001).

As concentrações médias horárias de sulfeto de hidrogênio $\left(\mathrm{H}_{2} \mathrm{~S}\right)$, metano $\left(\mathrm{CH}_{4}\right)$, monóxido de carbono $(\mathrm{CO})$, oxigênio $\left(\mathrm{O}_{2}\right)$ e amônia $\left(\mathrm{NH}_{3}\right)$ na sala de gestação são apresentadas na Tabela 10 . 
Tabela 10.Concentração média horária dos gases $\mathrm{H}_{2} \mathrm{~S}, \mathrm{CO}, \mathrm{CH}_{4}, \mathrm{O}_{2}$ e $\mathrm{NH}_{3}$ no interior da sala de gestação

\begin{tabular}{cccccccccccc}
\hline Gases & \multicolumn{1}{c}{ Horários } \\
& $7: 00$ & $8: 00$ & $9: 00$ & $10: 00$ & $11: 00$ & $12: 00$ & $13: 00$ & $14: 00$ & $15: 00$ & $16: 00$ & $17: 00$ \\
\hline $\mathrm{H}_{2} \mathrm{~S}(\mathrm{ppm})$ & 0 & 0 & 0 & 0 & 0 & 0 & 0 & 0 & 0 & 0 & 0 \\
$\mathrm{CO}(\mathrm{ppm})$ & 0 & 0 & 0 & 0 & 0 & 0 & 0 & 0 & 0 & 0 & 0 \\
$\mathrm{CH}_{4}(\%)$ & 0 & 0 & 0 & 0 & 0 & 0 & 0 & 0 & 0 & 0 & 0 \\
$\mathrm{O}_{2}(\%)$ & 20,9 & 20,9 & 20,9 & 20,9 & 20,9 & 20,9 & 20,9 & 20,9 & 20,9 & 20,9 & 20,9 \\
$\mathrm{NH}_{3}(\mathrm{ppm})$ & 2,1 & 1,9 & 1,0 & 0,7 & 1,5 & 1,4 & 2,5 & 3,9 & 5,1 & 6,6 & 7,2 \\
\hline
\end{tabular}

As concentrações de sulfeto de hidrogênio $\left(\mathrm{H}_{2} \mathrm{~S}\right)$ registradas foram inferiores a 1 ppm, correspondendo ao limite de resolução do equipamento, não se verificando problemas na concentração deste gás, considerando que o fluxo de ventilação higiênica na instalação estava dentro dos limites aceitáveis, conforme Chang et al. (2001).

De maneira análoga, as concentrações registradas para monóxido de carbono (CO) e metano $\left(\mathrm{CH}_{4}\right)$ foram inferiores a $1 \mathrm{ppm}$ e $1 \%$ de concentração em volume na mistura com o ar, respectivamente. As concentrações médias para os gases descritos acima estão dentro dos limites recomendados pela CIGR (1994) para os animais, não acarretando em problemas sanitários e doenças respiratórias nas fêmeas gestantes.

Os valores de oxigênio $\left(\mathrm{O}_{2}\right)$ se mantiveram dentro das condições de salubridade, verificando-se valores constantes da ordem de $20,9 \%$. A presença de oxigênio em nível adequado pode ser considerado um indicativo de que não há risco no ambiente quanto à presença dos gases asfixiantes $\left(\mathrm{CH}_{4}\right.$ e $\left.\mathrm{CO}_{2}\right)$, os quais deslocam o oxigênio, conforme descrito por Saliba \& Corrêa (2000).

Pode-se verificar que os valores obtidos para concentração de amônia $\left(\mathrm{NH}_{3}\right)$ no interior da instalação foram inferiores para as concentrações admitidas de 10 ppm, mesmo considerando o horário de pico às 17 horas, apresentando valor médio da ordem de 7,2 ppm (Larry et al., 1994). Atribui-se a baixa concentração de amônia na sala de gestação ao manejo adotado pela granja, que consistia na raspagem diária de dejetos nas baias individuais (manhã) e a lavagem das baias coletivas (tarde). 
Nota-se na Figura 23 que, em geral, os teores de amônia $\left(\mathrm{NH}_{3}\right)$ apresentaram uma variação crescente com o aumento da temperatura no interior da instalação, concordando com Aarnink \& Elzing (1998); Sampaio (2004).

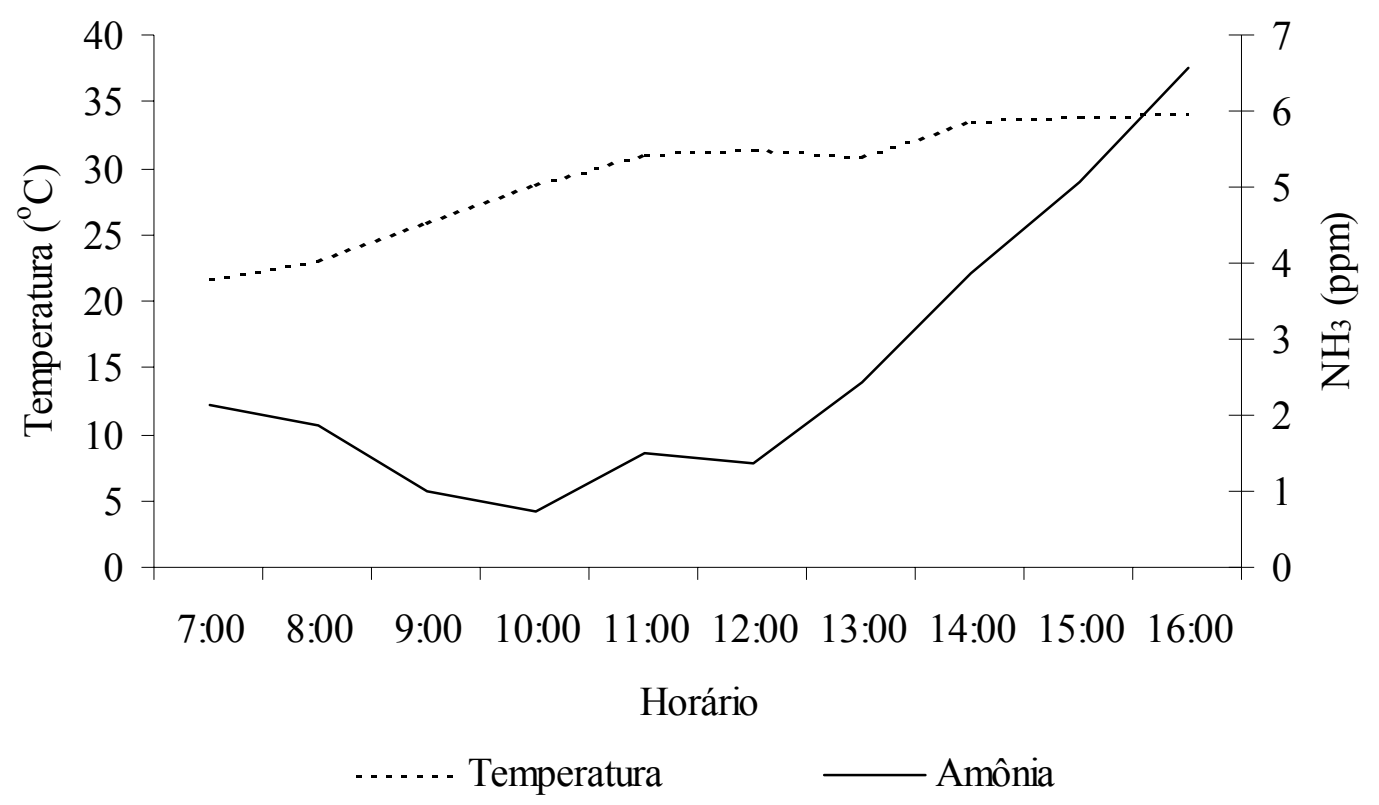

Figura 23 - Variação da concentração de amônia e da temperatura no interior da sala de gestação

Para os dados referentes à concentração de amônia em função da variação da temperatura, utilizou-se análise de regressão polinomial, envolvendo dados médios horários de registro, procurando melhor ajuste do modelo. Nota-se na Figura 24 que houve boa correlação entre as variáveis, apresentando um coeficiente de determinação de 0,86 , significativo a $1 \%$ de probabilidade pelo teste F. De acordo com o modelo desenvolvido para esta situação, a emissão deste gás apresenta um acréscimo de 2,45 até limites de $18,51 \%$ para cada aumento de $1{ }^{\circ} \mathrm{C}$ de temperatura. 


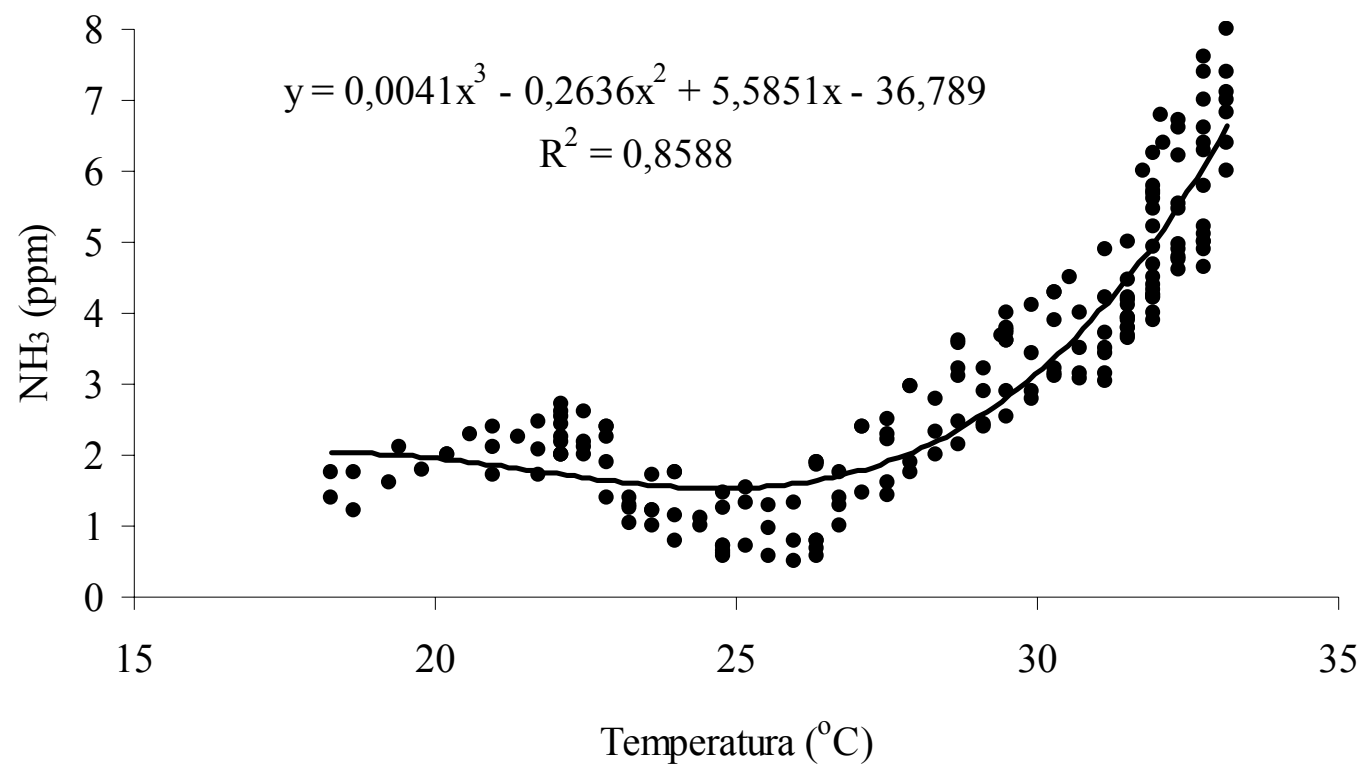

Figura 24 - Relação funcional entre concentração de amônia $\left(\mathrm{NH}_{3}\right)$ e a variação da temperatura no interior da instalação

As pequenas flutuações observadas entre os horários das 8 às 12 horas, em que não se verifica aumento na concentração de amônia com o aumento da temperatura, e devem-se ao fato da retirada dos dejetos logo após o arraçoamento, entre as 8 e 9 horas. Posteriormente à limpeza e com o acúmulo de excretas no decorrer do dia, a concentração de amônia varia mais acentuadamente com o aumento da temperatura (Figura 25). Além disso, observa-se neste período maior inatividade animal, ou seja, maior tempo de permanência na posição deitada ventral e lateral, haja vista que o piso nas baias individuais é semi-ripado o que permitia escoamento dos dejetos para o fosso, e os animais ao se deitarem impediam a mistura da amônia volatilizada com o ar, verificando-se menor teor de amônia no ar neste intervalo de tempo. Entretanto, no decorrer do dia, com o acúmulo de dejetos na sala de gestação, a influência da temperatura na concentração de $\mathrm{NH}_{3}$ fica mais evidente, independente da postura dos animais. 


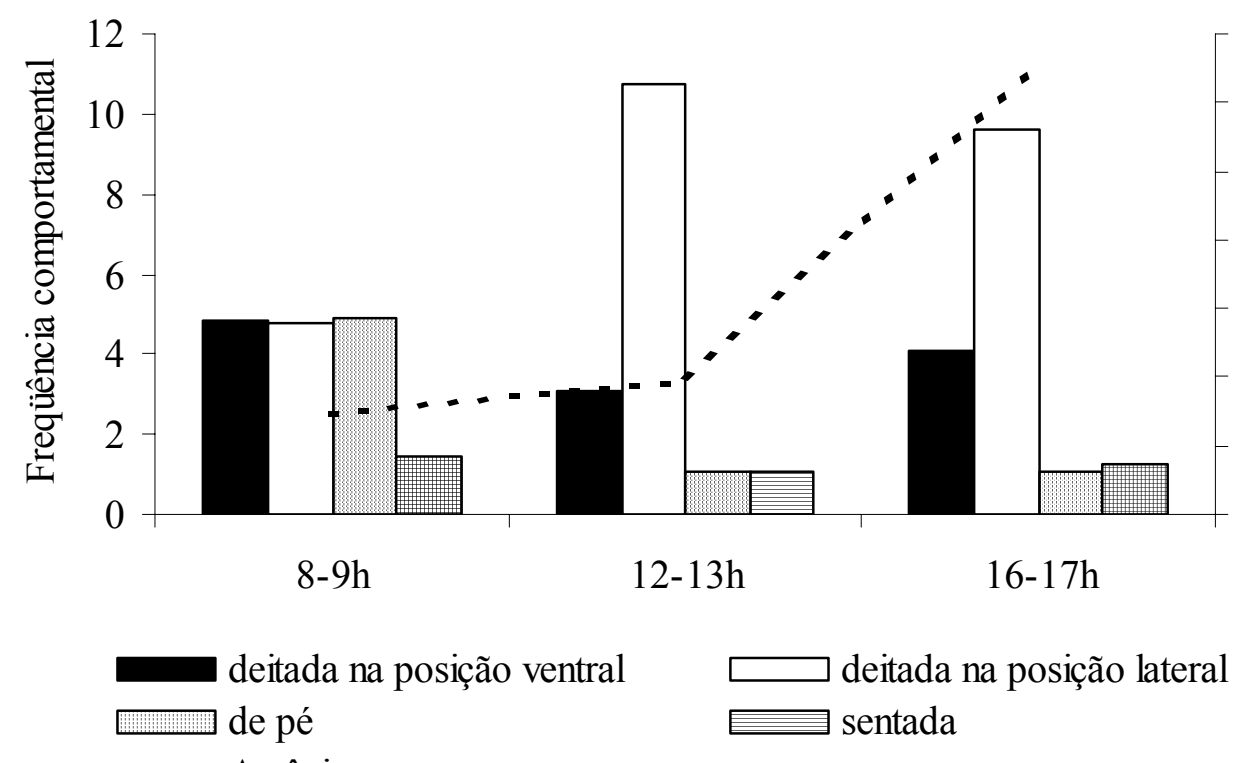

Figura 25 - Variação da concentração de amônia em relação à postura dos animais no interior da sala de gestação

Com relação à qualidade química do ar, os teores médios para os gases registrados no interior da instalação, na maior parte do tempo não superaram os valores considerados críticos para matrizes em fase de gestação. A concentração média de amônia $\left(\mathrm{NH}_{3}\right)$ registrada no centro geométrico da instalação a $1,20 \mathrm{~m}$ do piso se excedeu em alguns horários na parte da tarde, chegando a picos de $8 \mathrm{ppm}$, superando a concentração recomendada como segura de 7 ppm (Donham, 1999). Porém, este valor encontrado deve tratar de um caso típico de problemas relacionados à baixa taxa de renovação de ar, prejudicando a ventilação sanitária, pois a instalação encontrava-se em uma cota inferior ao setor de creche que funcionava como obstáculo à renovação de ar da estrutura, prejudicando principalmente os animais alojados nas baias individuais.

\subsection{Análise dos sistemas de produção}

\subsubsection{Parâmetros fisiológicos}


A Tabela 11 apresenta as médias das variáveis fisiológicas dos animais, taxa respiratória (mov.min. $\left.{ }^{-1}\right)$ e da temperatura retal $\left({ }^{\circ} \mathrm{C}\right)$ obtidas semanalmente durante o período experimental.

A taxa respiratória apresentou diferença estatística entre os tratamentos, baias individuais e baias coletivas, apresentando valores da ordem de 43 mov.min. ${ }^{-1}$ e 36 mov.min. ${ }^{-1}$ respectivamente, mostrando-se acima da condição de conforto para animais desta categoria. Fêmeas gestantes em condição de conforto térmico apresentam taxa respiratória em torno de 15 a 20 mov.min..$^{-1}$. Os movimentos respiratórios podem aumentar de 22 a 100\%, em função do ambiente térmico, de acordo com Hannas et al. (1999). Quando a taxa respiratória está elevada, admite-se que a temperatura do ar está próxima à temperatura corporal, o calor é armazenado no organismo e o valor da temperatura corporal aumenta acima dos valores normais e esta resposta é decorrente do estímulo direto ao centro de calor no hipotálamo que envia impulso ao sistema cardiorespiratório, na tentativa de eliminar calor por evaporação por meio da respiração, que neste caso apresenta um aumento marcante.

Com relação à temperatura retal, notam-se diferenças significativas entre os tratamentos, $38,91{ }^{\circ} \mathrm{C}$ (baias individuais) e $38,72{ }^{\circ} \mathrm{C}$ (baias coletivas), porém, para ambos os tratamentos a variação da temperatura retal encontra-se próximo à condição de conforto, variando entre 38,6 e $39,3{ }^{\circ} \mathrm{C}$. Para matrizes em gestação o valor considerado ótimo é de $38,6^{\circ} \mathrm{C}$. Mudanças na temperatura retal são observadas em animais submetidos ao estresse por calor, no entanto, ocorrem quando o mecanismo de perda de calor evaporativo está sendo insuficiente (Muirhead \& Alexander, 1997).

Tabela 11. Médias das variáveis fisiológicas no período experimental

\begin{tabular}{lcc}
\hline Tratamentos & Taxa respiratória (mov.min..$\left.^{-1}\right)$ & Temperatura retal $\left({ }^{\circ} \mathrm{C}\right)$ \\
\hline Baias individuais & $43 \mathrm{a}$ & $38,91 \mathrm{~b}$ \\
Baias coletivas & $36 \mathrm{~b}$ & $38,72 \mathrm{a}$ \\
\hline Valores médios com letras diferentes, na mesma coluna, diferem estatisticamente pelo Teste de Tukey, $\mathrm{P}<$ \\
0,01
\end{tabular}

A modificação do ambiente e a utilização de recursos de resfriamento podem auxiliar a termorregulação animal e reduzir os efeitos do ambiente térmico sobre as 
respostas fisiológicas. No entanto, o efeito do sistema de nebulização para as baias individuais (T1) não foi suficiente para redução da taxa respiratória e da temperatura retal, frente à supressão das matrizes em baias individuais, que promoveram reflexo direto no conforto dos animais, devido ao estresse crônico causado pela restrição de espaço.

\subsection{2 Índices Zootécnicos}

Verifica-se na Tabela 12 a comparação entre as médias observadas nos tratamentos sobre a resposta aos índices zootécnicos: período de gestação em dias, duração do parto em minutos, número de leitões nascidos vivos, natimortos e mumificados, peso dos leitões no nascimento, peso no desmame e mortalidade. Para efeito de comparação, considera-se um total de 24 matrizes, 12 alojadas em baias individuais e 12 em baias coletivas e um total de 115 leitões provenientes das fêmeas alojadas em baias individuais e 131 leitões dos animais em baias coletivas. Todos os índices avaliados não apresentaram diferenças estatísticas entre tratamentos.

Tabela 12. Valores médios dos índices zootécnicos na fase de gestação e maternidade para os animais submetidos ao regime de confinamento em baias individuais e coletivas durante a gestação

\begin{tabular}{lcc}
\hline Índices zootécnicos & \multicolumn{2}{c}{ Tratamentos } \\
& Baias individuais & Baias coletivas \\
\hline Gestação (dias) & $113,63 \mathrm{a}$ & $113,50 \mathrm{a}$ \\
Duração do parto (min) & $181 \mathrm{a}$ & $152 \mathrm{a}$ \\
Tamanho da leitegada & $9,99 \mathrm{a}$ & $10,99 \mathrm{a}$ \\
Nascidos vivos & $9,58 \mathrm{a}$ & $10,25 \mathrm{a}$ \\
Natimortos & $0,66 \mathrm{a}$ & $0,66 \mathrm{a}$ \\
Mumificados & $0,25 \mathrm{a}$ & $0,08 \mathrm{a}$ \\
Peso no nascimento $(\mathrm{kg})$ & $1,19 \mathrm{a}$ & $1,23 \mathrm{a}$ \\
Peso no desmame(kg) & $5,11 \mathrm{a}$ & $5,34 \mathrm{a}$ \\
Mortalidade (\%) & $22,54 \mathrm{a}$ & $17,49 \mathrm{a}$ \\
\hline Valores médios com letras diferentes, na mesma linha, diferem estatisticamente pelo Teste de Tukey, $\mathrm{P}<$ \\
0,01
\end{tabular}


A gestação da fêmea suína apresenta uma período de duração em torno de 115 dias ( 3 meses, 3 semanas e 3 dias), com pequenas variações observadas entre granjas ou raças, para mais ou menos três dias (112 a 118 dias). Nota-se que não houve diferença estatística na duração do período de gestação, para os dois tratamentos avaliados, baias individuais e coletivas, apresentando valores médios de 113,63 e 113,50 dias, respectivamente, encontrando-se dentro dos limites esperados, em que não foram detectadas patologias que pudessem prolongar o período de gestação para ambos os tratamentos.

A duração do parto nas fêmeas alojadas em baias individuais mostrou-se superior, quando comparadas às baias coletivas, porém, não significativo, verificando-se valores médios da ordem de 181 e 152 minutos respectivamente. Quanto maior a duração do parto, maior o número de natimortos (Friend, et al., 1962; Cavalcanti, et al., 1979). A duração do parto pode ser influenciado negativamente por inúmeros fatores, principalmente o ambiente e o manejo. Assim, altas temperaturas, níveis acentuados de ruídos e demais fatores estressantes, tendem a induzir a secreção de adrenalina e de determinadas catecolaminas que bloqueiam a ação da ocitocina, interferindo nas contrações uterinas (Naktgeboren, 1972). Porém, todas as fêmeas foram higienizadas e transferidas à maternidade em um período de três dias antes do parto, com o objetivo de reduzir o estresse causado pela mudança do ambiente. Todos os animais foram alojados numa mesma sala de maternidade em celas individuais, e a duração do parto, em ambos os tratamentos, mantiveram-se próximos da média admitida de 3 horas.

Os dados referentes ao tamanho da leitegada, contabilizaram um leitão a mais para o T2, o que pode significar um acréscimo de 2400 animais terminados por ano em relação ao T1, gerando uma receita adicional de $\mathrm{R} \$ 449.280,00$, considerando cotação de $\mathrm{R} \$ 2,08 / \mathrm{kg}$ vivo de suíno, e peso ao abate de $90 \mathrm{~kg}$.

O número de leitões nascidos vivos apresentou variação entre tratamentos, o tamanho da leitegada no $\mathrm{T} 1$ foi de 9,58, ao passo que no $\mathrm{T} 2$ o valor encontrado foi de 10,25. Os principais fatores que influenciam diretamente o tamanho da leitegada são: ordem de parto, idade da matriz na concepção, número de coberturas por cio, época do ano (temperatura e fotoperíodo), nutrição e sanidade (Clark \& Leman, 1986). 
Admitindo-se que esses fatores de interferência foram controlados, possivelmente essa variação poderia ser atribuída ao estresse crônico causado pela falta de espaço às matrizes em baias individuais de gestação.

Os problemas de má formação, leitões mumificados e de natimortos, apresentaram valores de 0,25 mumificados nascidos das matrizes alojadas em baias individuais na fase de gestação e de 0,08 provenientes de matrizes alojadas em baias coletivas. Para os natimortos, verificou-se valor de 0,66 para ambos os tratamentos.

Para que um leitão tenha uma boa possibilidade de desenvolvimento, seu peso mínimo deve ser igual ou superior a $1,2 \mathrm{~kg}$, ou de 0,7 a $1,2 \mathrm{~kg}$, no caso de transferência cruzada de leitões em instalações em que se trabalha com grupos de fêmeas, que neste caso possibilitou a transferência de animais entre as fêmeas de cada um dos tratamentos estudados. Desta maneira, a leitegada foi constituída por leitões com peso uniforme, o que lhe permitiu melhor desenvolvimento. Neste contexto, verifica-se que o peso no nascimento dos leitões oriundos das fêmeas alojadas em baias individuais de gestação apresentou peso médio de $1,19 \mathrm{~kg}$ e das matrizes em baias coletivas de 1,23 kg. Em ambas as situações, nota-se que o ganho de peso médio diário atingiu os valores mínimos exigidos de aproximadamente $0,185 \mathrm{~kg} \cdot \mathrm{dia}^{-1}$, garantindo um desmame aos 21 dias de 5,11 kg para os leitões relacionados às matrizes submetidas ao $\mathrm{T} 1 \mathrm{e}$ de 5,33 $\mathrm{kg}$ para o T2 (Mores et al., 1998).

A mortalidade dos leitões relacionados às mães e seus respectivos tratamentos apresentaram valores de $22,54 \%$ para $\mathrm{T} 1$ e de $17,49 \%$ em $\mathrm{T} 2$, valores estes que se encontram próximos da porcentagem admitida de $25 \%$ para animais nascidos com peso médio entre 1,1 e 1,2 kg (Mores et al., 1998).

Com relação ao desempenho dos leitões, observa-se que as matrizes submetidas às baias coletivas na fase de gestação tiveram condições de proporcionar melhor desenvolvimento aos leitões, verificando-se índices superiores para peso dos leitões no nascimento e no desmame, e uma menor mortalidade em relação às matrizes confinadas em baias individuais. 
Esses acréscimos, mesmo que alguns sejam de ordem decimal, apresentam um reflexo direto no computo geral da propriedade, garantido o sucesso econômico do negócio, aumentando os lucros, viabilizando as alterações no sistema de confinamento.

\subsubsection{Análise comportamental}

A avaliação do bem-estar animal na exploração zootécnica pode envolver aspectos ligados às instalações, ao manejo, ao ambiente e principalmente à resposta do animal ao meio, relacionada à observação do dia a dia na unidade de produção, procurando interpretar a linguagem animal, ou seja, a resposta comportamental frente aos regimes de criação.

Para análise da freqüência e da porcentagem de variação das classes comportamentais: atividade, estereotipia, interações sociais, interações agressivas e suas respectivas especificações (Tabela 13), os padrões comportamentais foram registrados semanalmente, um dia por semana durante o período experimental, totalizando nove dias de observação. Dessa forma, adotando-se o intervalo de 4 minutos entre jornadas de imagens registradas, selecionaram-se três horários para análise, das 8 às 9 horas, das 12 às 13 e das 16 às 17 horas, permitindo observação individual de seis animais selecionados em cada tratamento (Rudkin \& Stewart, 2003).

Nota-se, na Tabela 13, que a inatividade dos animais apresenta cerca de 49,88\% do tempo total de observação, apresentando pequena diferença entre tratamentos, $0,8 \%$ superior para o sistema de alojamento em baias individuais. Com relação aos demais comportamentos que englobam a classe de atividades, verifica-se que os animais alojados em baias coletivas permanecem inativos em alerta $2,08 \%$ acima do tempo de observação dos animais em baias individuais, caracterizando, desta forma, a maior possibilidade de explorar o ambiente, o que se evidencia pelo ato de cheirar o piso realizando movimentos circulares, comportamento este mais marcante na condição de baias coletivas, representando cerca de $1,74 \%$ do tempo de observação, ao passo que para o sistema de confinamento em baias individuais verifica-se a porcentagem de 0,69\%, devido à própria restrição de liberdade de movimento e exploração do meio. 
Tabela 13. Freqüência e porcentagem média da variação comportamental, atividade, estereotipia, interação social e agressiva das matrizes alojadas em sistemas de contenção em baias individuais e coletivas

\begin{tabular}{|c|c|c|c|}
\hline $\begin{array}{c}\text { Freqüência } \\
\text { Porcentagem }(\%)\end{array}$ & $\begin{array}{c}\text { Baias } \\
\text { individuais }\end{array}$ & $\begin{array}{c}\text { Baias } \\
\text { coletivas }\end{array}$ & Total \\
\hline ATIVIDADE & & & \\
\hline Inativo & $\begin{array}{c}219 \\
25,35\end{array}$ & $\begin{array}{c}212 \\
24,54\end{array}$ & $\begin{array}{c}431 \\
49,88\end{array}$ \\
\hline Inativo (alerta) & $\begin{array}{c}37 \\
4,28\end{array}$ & $\begin{array}{c}55 \\
6,37\end{array}$ & $\begin{array}{c}92 \\
10,65\end{array}$ \\
\hline Cheirar & $\begin{array}{c}6 \\
0,69\end{array}$ & $\begin{array}{c}15 \\
1,74\end{array}$ & $\begin{array}{c}21 \\
2,43\end{array}$ \\
\hline Beber & $\begin{array}{c}19 \\
2,20\end{array}$ & $\begin{array}{c}12 \\
1,39\end{array}$ & $\begin{array}{c}31 \\
3,59\end{array}$ \\
\hline ESTEREOTIPIA & & & \\
\hline Movimentar a língua & $\begin{array}{c}2 \\
0,23\end{array}$ & $\begin{array}{c}1 \\
0,12\end{array}$ & $\begin{array}{c}3 \\
0,35\end{array}$ \\
\hline Lamber & $\begin{array}{c}22 \\
2,55\end{array}$ & $\begin{array}{c}17 \\
1,97\end{array}$ & $\begin{array}{c}39 \\
4,51\end{array}$ \\
\hline Abrir e fechar a boca & $\begin{array}{c}2 \\
0,23\end{array}$ & $\begin{array}{c}1 \\
0,12\end{array}$ & $\begin{array}{c}3 \\
0,35\end{array}$ \\
\hline Morder & $\begin{array}{c}50 \\
5,79\end{array}$ & $\begin{array}{c}0 \\
0,00\end{array}$ & $\begin{array}{c}50 \\
5,79\end{array}$ \\
\hline Beber & $\begin{array}{c}21 \\
2,43\end{array}$ & $\begin{array}{c}1 \\
0,12\end{array}$ & $\begin{array}{c}22 \\
2,55\end{array}$ \\
\hline Esticar o pescoço & $\begin{array}{c}4 \\
0,46\end{array}$ & $\begin{array}{c}0 \\
0,00\end{array}$ & $\begin{array}{c}4 \\
0,46\end{array}$ \\
\hline Fuçar & $\begin{array}{c}21 \\
2,43\end{array}$ & $\begin{array}{c}69 \\
7,99\end{array}$ & $\begin{array}{c}90 \\
10,42\end{array}$ \\
\hline INTERAÇÃO SOCIAL & & & \\
\hline Lambiscar & $\begin{array}{c}0 \\
0,00\end{array}$ & $\begin{array}{c}2 \\
0,23\end{array}$ & $\begin{array}{c}2 \\
0,23\end{array}$ \\
\hline Cheirar & $\begin{array}{c}26 \\
3,01\end{array}$ & $\begin{array}{c}38 \\
4,40\end{array}$ & $\begin{array}{c}64 \\
7,41\end{array}$ \\
\hline Lamber & $\begin{array}{c}3 \\
0,35\end{array}$ & $\begin{array}{c}9 \\
1,04\end{array}$ & $\begin{array}{c}12 \\
1,39\end{array}$ \\
\hline INTERAÇÃO AGRESSIVA & & & \\
\hline Empurrar & $\begin{array}{c}0 \\
0,00\end{array}$ & $\begin{array}{c}0 \\
0,00\end{array}$ & $\begin{array}{c}0 \\
0,00\end{array}$ \\
\hline Morder & $\begin{array}{c}0 \\
0,00\end{array}$ & $\begin{array}{c}0 \\
0,00\end{array}$ & $\begin{array}{c}0 \\
0,00\end{array}$ \\
\hline Brigar & $\begin{array}{c}0 \\
0,00\end{array}$ & $\begin{array}{c}0 \\
0,00\end{array}$ & $\begin{array}{c}0 \\
0,00\end{array}$ \\
\hline Perseguir & $\begin{array}{c}0 \\
0,00\end{array}$ & $\begin{array}{c}0 \\
0,00\end{array}$ & $\begin{array}{c}0 \\
0,00\end{array}$ \\
\hline Ameaçar & $\begin{array}{c}0 \\
0,00\end{array}$ & $\begin{array}{c}0 \\
0,00\end{array}$ & $\begin{array}{c}0 \\
0,00\end{array}$ \\
\hline Total & $\begin{array}{c}432 \\
50,00\end{array}$ & $\begin{array}{c}432 \\
50,00\end{array}$ & $\begin{array}{c}864 \\
100,00\end{array}$ \\
\hline
\end{tabular}


$\mathrm{O}$ acesso dos animais ao bebedouro foi determinado pela necessidade hídrica diária dos animais. A ida ao bebedouro ou à "chupeta" representava exclusivamente uma atividade normal dos animais. Pode-se observar que o tempo despendido ao bebedouro foi de $1,39 \%$ para as matrizes alojadas em baias coletivas e de $2,20 \%$ para os animais em baias individuais.

Em geral, os comportamentos estereotipados foram mais evidentes no sistema de alojamento em baias individuais, representando cerca de $14,12 \%$ do tempo total de observação, aproximadamente 3,80\% superior às baias coletivas, em virtude da restrição de espaço nas baias individuais. Resultados semelhantes a este também foram encontrados por Broom (1991); Mendl et al. (1992); Vieuille-Thomas et al. (1995). Esta diferença não foi mais acentuada, pelo fato dos animais serem submetidos a um manejo de restrição alimentar, o que possivelmente levou as matrizes confinadas em baias coletivas a expressarem um comportamento natural instintivo, como o ato de fuçar. No entanto, a prática de fuçar piso sólido sem que haja substrato (cama), evidenciando a necessidade de explorar o ambiente na busca por alimento, caracteriza-se como uma estereotipia, que neste caso apresentou valor da ordem de $7,99 \%$ para baias coletivas e $2,43 \%$ para as baias individuais.

As interações sociais foram facilitadas no alojamento em baias coletivas, onde eram permitidos aos animais maior contato e liberdade de movimento, verificando-se cerca de $5,67 \%$ do tempo de análise. Já para as baias coletivas a possibilidade de contato estava restrita apenas ao animal vizinho. Desta forma, observa-se $3,36 \%$ do total dos comportamentos avaliados.

Verifica-se na Tabela 13 que as interações agressivas foram pouco evidentes, ou praticamente irrelevantes numa condição média. Este acontecimento pode ser explicado pelo fato dos animais permanecerem agrupados em baias coletivas até o momento da inseminação, o que possibilitou o estabelecimento de uma hierarquia social organizada e ampliou o grau de conhecimento entre os animais, e, quando reagrupados, não se observaram problemas sociais, tanto nas baias coletivas quanto nas individuais (Van de Burgwal, 1990; Olsson \& Svendsen, 1995; Spoolder et al., 1996). 
De acordo com Fraser \& Broom, 1997, outro momento crítico ao aumento da agressividade entre os animais seria no arraçoamento, pela disputa por comida, nos cochos ou no chão, porém, por se tratar de um sistema de fornecimento de ração controlado, uma vez ao dia, as observações comportamentais entre as 7 e 8 horas foram desconsideradas.

Pode-se verificar, na Tabela 14, a variação comportamental de postura entre os animais submetidos aos seus respectivos tratamentos, assim como suas freqüências e porcentagens médias para permanência deitados na posição ventral ou lateral, sentados, em pé e ajoelhados. Quando se trata das posturas comportamentais, deve-se ressaltar que cada postura está sempre associada a um dos demais comportamentos apresentados na Tabela 13.

Desta forma, analisando-se a postura deitado na posição lateral, verifica-se que em ambos os tratamentos a porcentagem do tempo de permanência nesta posição é muito próximo, cerca de $25,46 \%$ para baias individuais e $25,23 \%$ para baias coletivas, a exemplo do que acontece com a inatividade dos animais, pela razão destes comportamentos estarem associados na maioria dos casos.

Os animais assumem a posição deitados ventralmente em cerca de 10,76\% nas baias coletivas e em $12,15 \%$ nas individuais, ao passo que a permanência das matrizes em pé, representando o momento de deslocamento dos animais nas baias coletivas e a mudança de postura nas individuais, apresentam valores da ordem de 13,43\% para as baias coletivas e de 7,87\% para as individuais, evidenciando-se a maior disponibilidade de espaço no tratamento baia coletiva (Anil et al, 2002).

A permanência dos animais na posição sentada é mais evidente nas baias individuais, $4,40 \%$ do total analisado, e de $0,58 \%$ para as baias coletivas. A postura ajoelhada não foi registrada na condição de baias coletivas e apresentou uma reduzida porcentagem para as baias individuais, cerca de $0,12 \%$, possivelmente por se tratar de uma postura de transição. 
Tabela 14. Freqüência e porcentagem média da variação comportamental de postura das matrizes alojadas em sistemas de contenção em baias individuais e coletivas

\begin{tabular}{lccc}
\hline \multicolumn{1}{c}{$\begin{array}{c}\text { Freqüência } \\
\text { Porcentagem (\%) }\end{array}$} & Baias individuais & Baias coletivas & Total \\
\hline Postura & & & \\
Deitar na posição ventral & 105 & 93 & 198 \\
& 12,15 & 10,76 & 22,92 \\
Deitar na posição lateral & 220 & 218 & 438 \\
& 25,46 & 25,23 & 50,69 \\
Em pé & 68 & 116 & 184 \\
& 7,87 & 13,43 & 21,30 \\
Ajoelhar & 1 & 0 & 1 \\
& 0,12 & 0,00 & 0,12 \\
Sentar & 38 & 5 & 43 \\
& 4,40 & 0,58 & 4,98 \\
Total & 432 & 432 & 864 \\
& 50,00 & 50,00 & 100,00 \\
\hline
\end{tabular}

De acordo com a Figura 26, observa-se que no horário das 8 às 9 horas, as classes comportamentais, atividade, estereotipia, interações sociais e agressivas, apresentam a seguinte variação percentual para baias individuais e coletivas: $48 \%$ e $48 \%$ para atividade, 44 e 38\% para estereotipia, 8 e 13\% para interação social e 0 e $1 \%$ para interação agressiva, respectivamente. A variação percentual para as diferentes classes de comportamento são reflexos de um período de grande movimentação, em virtude do arraçoamento dos animais, no período das 7 às 8 horas, permanecendo mais ativos após a alimentação (Broom, 1987). 
a)

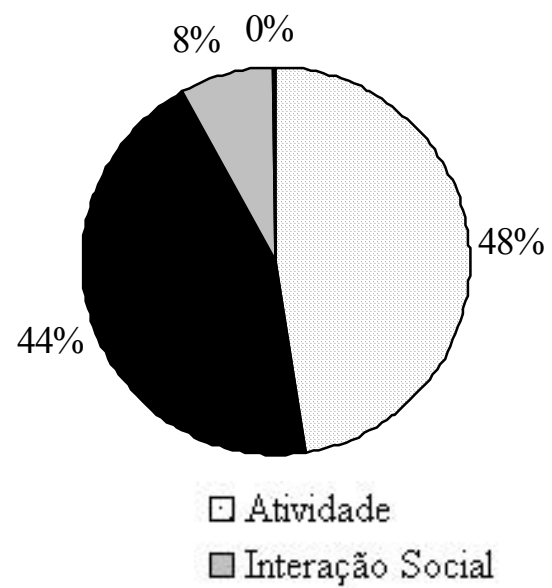

b)

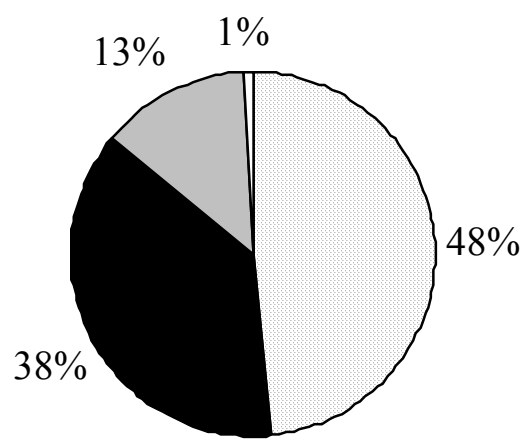

Estereotipia

$\square$ Interação agressiva

Figura 26 - Variação comportamental das matrizes alojadas em baias individuais (a) e coletivas (b) no horário das 8 às 9 horas

Para o horário das 12 às 13 horas, nota-se uma maior porcentagem para a classe atividade, apresentando valores superiores para as baias individuais e coletivas, comparando-se com o horário anterior, das 8 às 9 horas. De maneira análoga à análise geral das médias, sabe-se que a maior contribuição para valores de 74 e $71 \%$ para baias individuais e coletivas, respectivamente, se deve à manifestação do ócio entre os animais, caracterizado pelos períodos de inatividade e/ou inatividade em estado de alerta.

Com relação às estereotipias, estas foram menos acentuadas que no horário anterior, apresentando valores da ordem de 22 e $15 \%$ para baias individuais e coletivas, respectivamente. Quanto às interações sociais e agressivas, estas se mantiveram praticamente constantes em relação ao horário das 8 às 9 horas, exceto para baia individual que apresentou uma redução de 4\% durante o horário de análise (Figura 27). 
a)

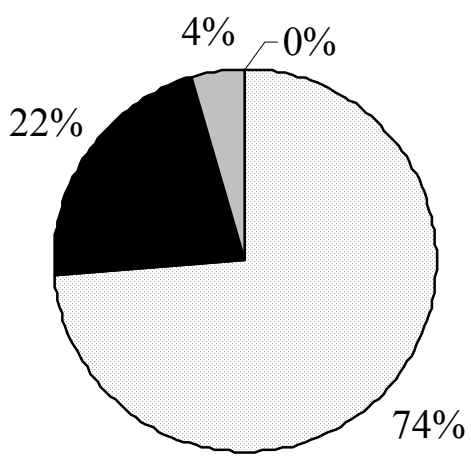

$\square$ Atividade

$\square$ Interação Social b)

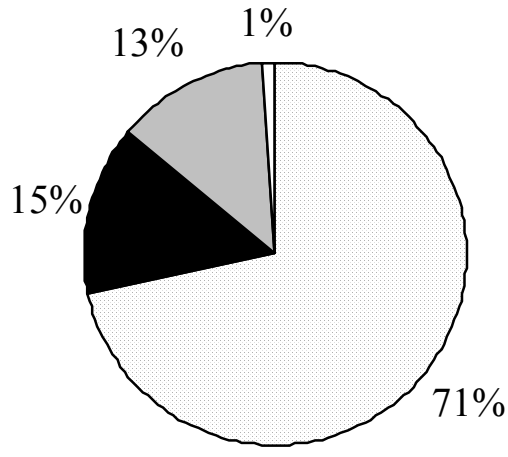

Estereotipia

$\square$ Interação agressiva

Figura 27 - Variação comportamental das matrizes alojadas em baias individuais (a) e coletivas (b) no horário das 12 às 13 horas

No horário das 16 às 17 horas, o período de inatividade e/ou inatividade em estado de alerta, salvo algumas manifestações de outros comportamentos da classe atividade, apresentou cerca de $83 \%$ do horário analisado para a situação de alojamento em baias coletivas e de $72 \%$ em baias individuais. A estereotipia foi mais acentuada nas baias individuais, apresentando cerca de $23 \%$ para as baias individuais e $10 \%$ para as coletivas, assim como nos horários anteriores que contaram com uma diferença da ordem de $7 \%$ para o horário das 12 às 13 e de $6 \%$ para o horário das 8 às 9 horas, valores estes superiores para baias individuais, comparativamente às baias coletivas. Em relação às interações sociais, nota-se valor de 7\% para baias coletivas e 5\% para as individuais. Esta variação também se verifica nos demais horários, 8 às 9 e das 12 às 13 horas, com diferenças de 8\% e 9\%, superior para as baias coletivas (Figura 28). 
a)

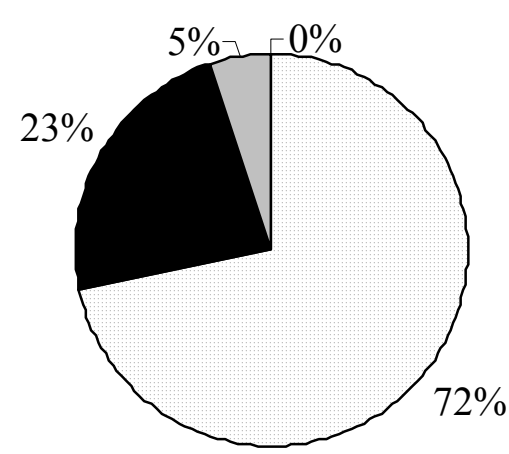

$\square$ Atividade

$\square$ Interação Social b)

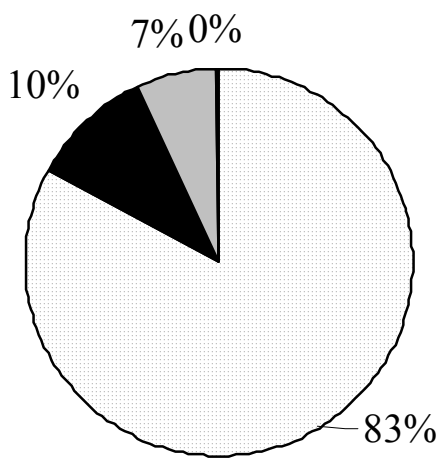

- Estereotipia

$\square$ Interação agressiva

Figura 28 - Variação comportamental das matrizes alojadas em baias individuais (a) e coletivas (b) no horário das 16 às 17 horas

Referindo-se ao perfil de variação comportamental das matrizes alojadas em baias individuais (BI) e coletivas (BC), verifica-se para classe comportamental de atividades em relação à variação entálpica para os horários de observação das 8 às 9 horas, com entalpia na faixa de $63 \mathrm{~kJ} . \mathrm{kg}^{-1}$ para BI e de $61 \mathrm{~kJ} \cdot \mathrm{kg}^{-1}$ para BC que a tempo de inatividade e inatividade em estado de alerta foram menores em relação às observações nos horários posteriores. Com o aumento da entalpia, estes comportamentos apresentaram sensível aumento, reduzindo as demais atividades, ou seja, o incremento de calor no ambiente promoveu a prostração das fêmeas na tentativa de potencializar as perdas de calor sensível por contato tanto nas baias individuais quanto nas coletivas (Figura 29). 


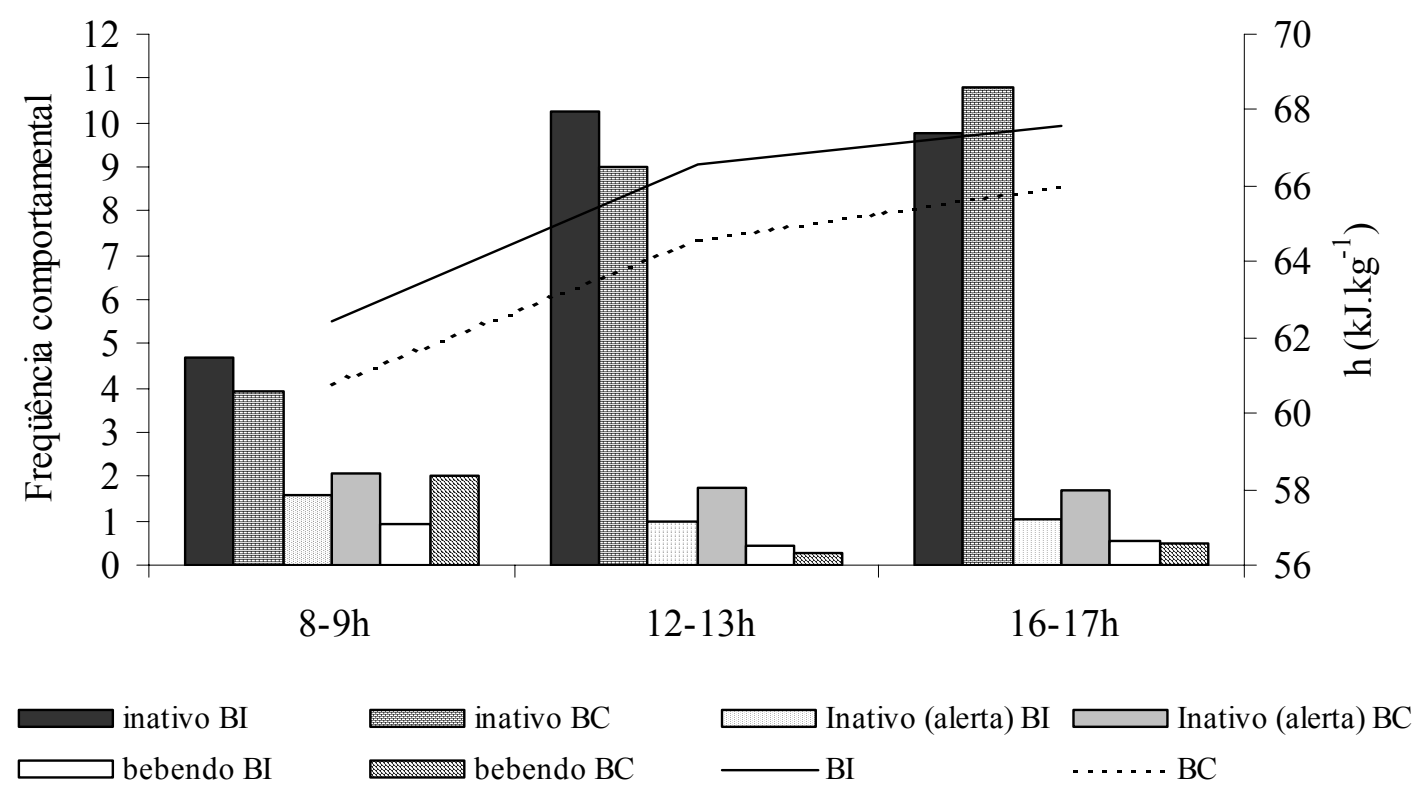

Figura 29 - Variação das atividades comportamentais e entalpia para os dois sistemas de contenção, baias individuais e coletivas

De acordo com a Figura 30, pode-se observar que, para os comportamentos esteriotipados, aquele que demonstra ser mais sensível à variação da entalpia é o ato de morder barras nas baias individuais e de fuçar nas baias coletivas, sendo mais evidentes no horário das 8 às 9 horas, intervalo em que os animais estão mais ativos, decrescendo à medida que a curva de entalpia aumenta.

Com relação à postura dos animais, verifica-se que as matrizes apresentam-se, na maior parte do tempo, deitadas na posição lateral, tanto nas baias coletivas quanto nas individuais, e, em função do aumento da entalpia no decorrer dos horários analisados, observa-se que estas posturas ganham preferência com o aumento da entalpia no decorrer do tempo (Figura 31). 


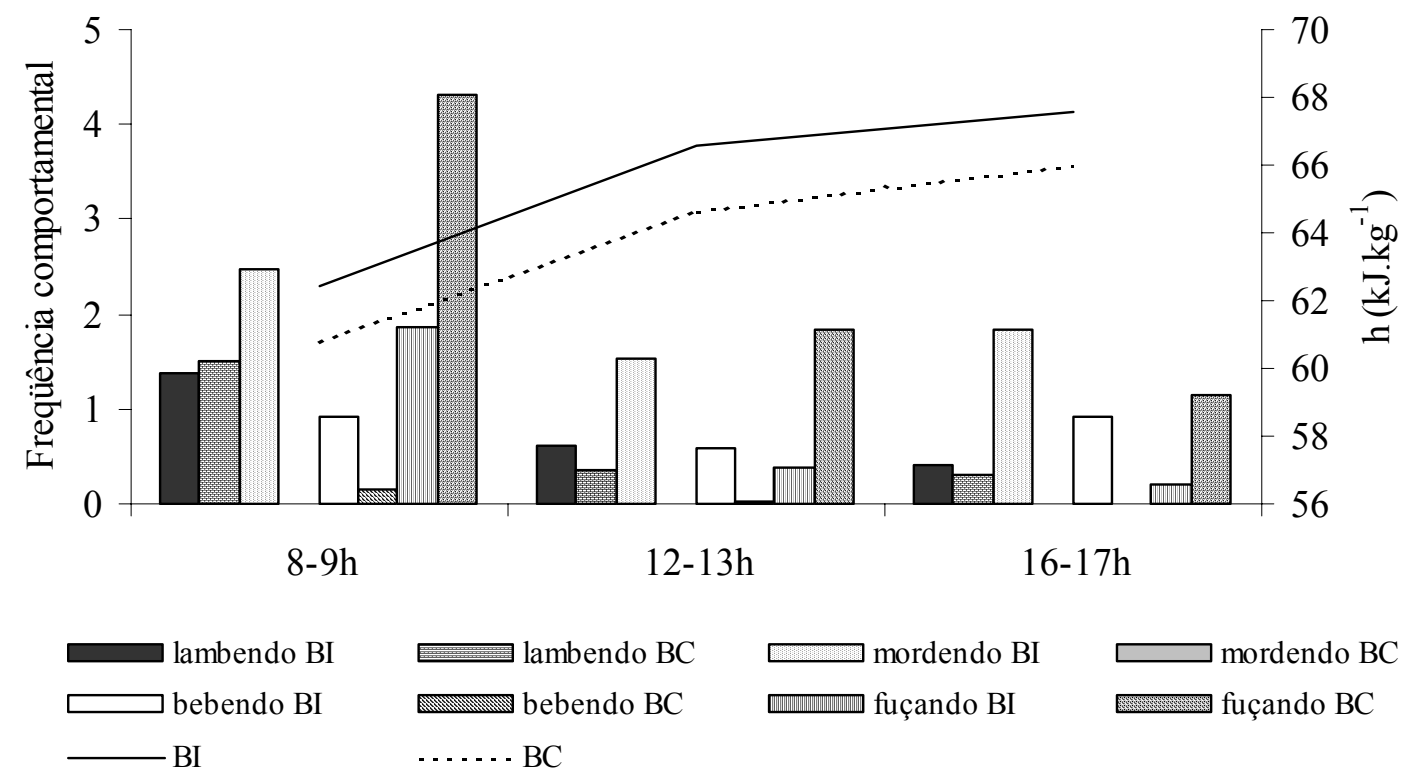

Figura 30 - Variação dos comportamentos estereotipados e entalpia para os dois sistemas de contenção, baias individuais e coletivas
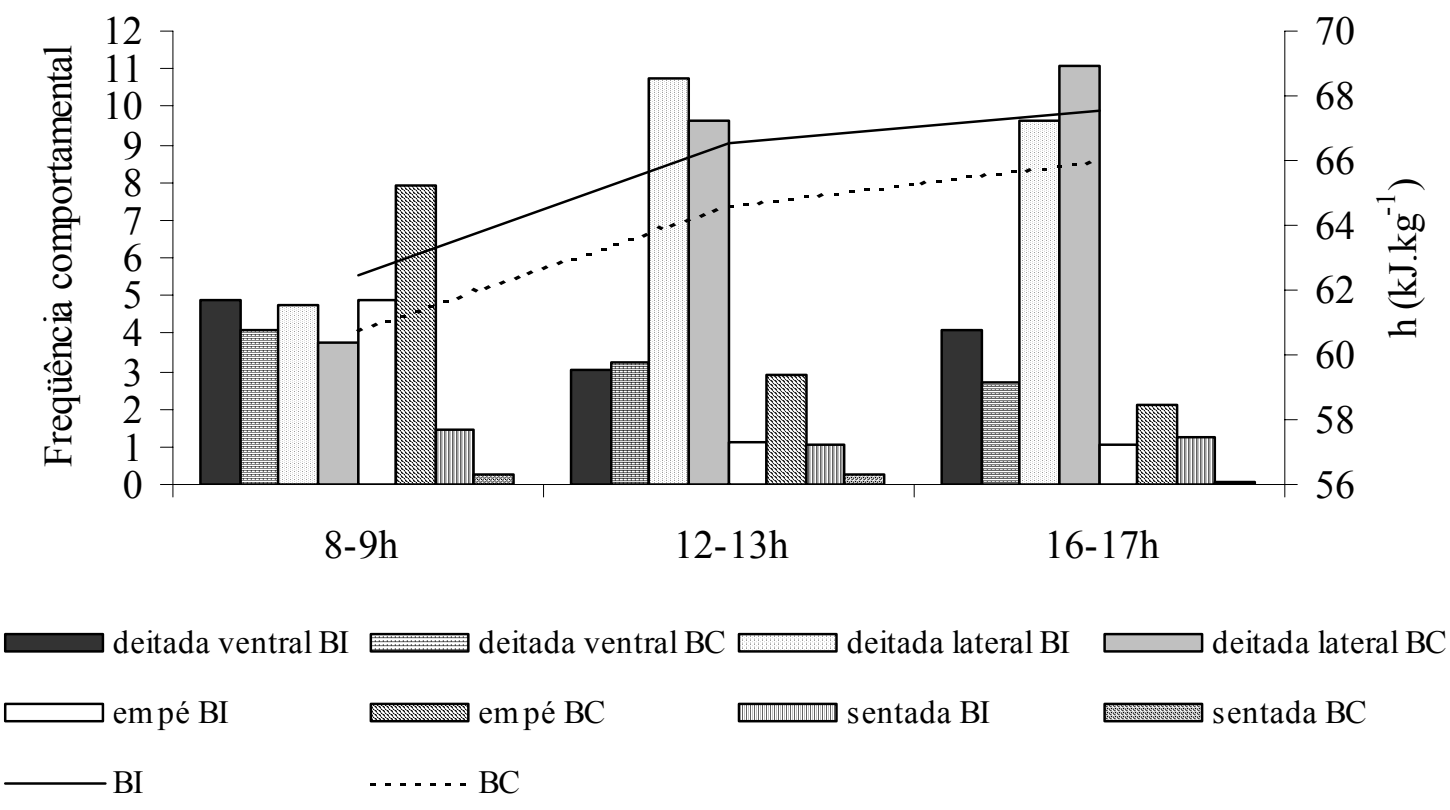

Figura 31 - Variação das posturas e entalpia para os dois sistemas de contenção, baias individuais e coletivas 
As interações sociais mostram-se mais evidentes nos dois primeiros horários, em ambos os tratamentos estudados. Já no terço final, entre as 16 e 17 horas, as interações apresentam uma marcante redução com o aumento da entalpia (Figura 32).

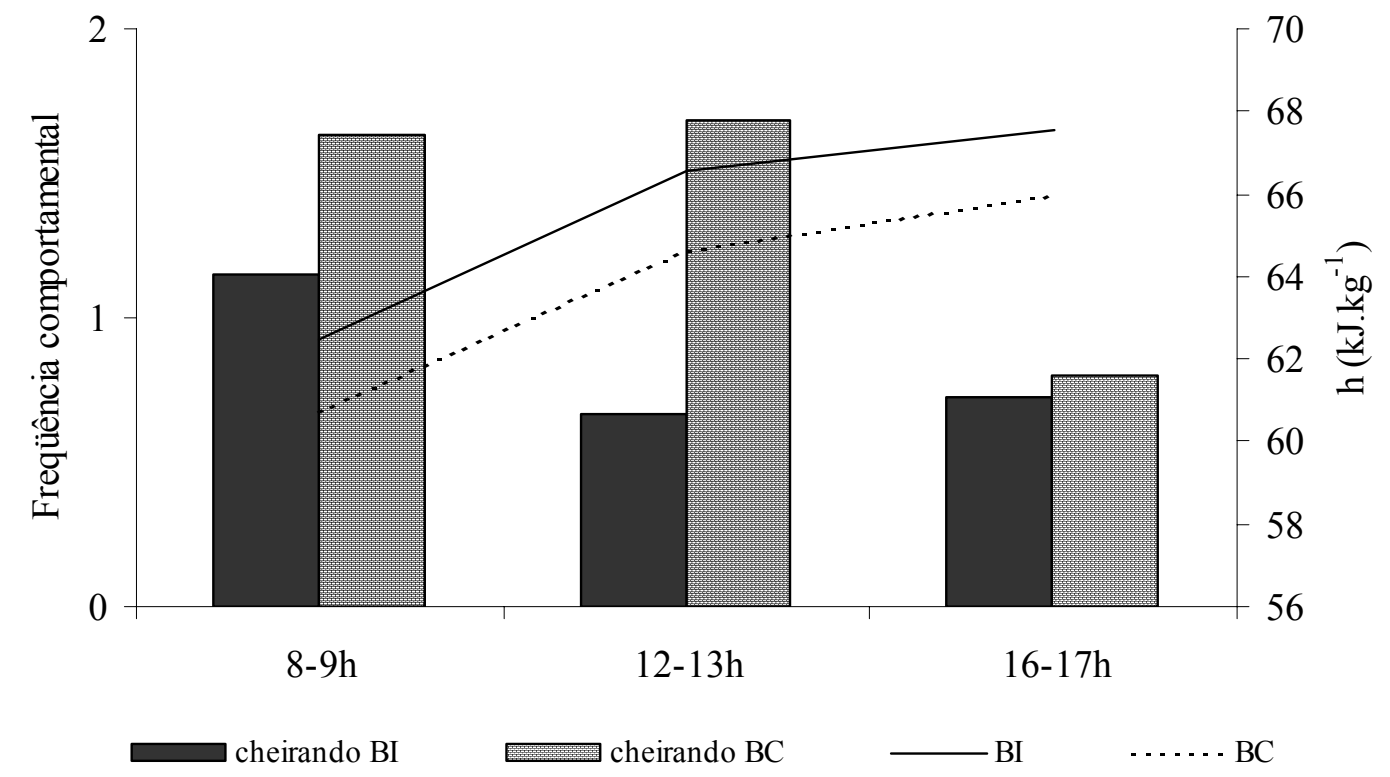

Figura 32 - Variação das interações sociais e entalpia para os dois sistemas de contenção, baias individuais e coletivas

Com base na análise das variáveis comportamentais, verifica-se que a condição de alojamento de matizes gestantes em baias individuais, promove limitação na liberdade de movimento e privação dos comportamentos normais instintivos, evidenciando-se maior incidência de estereotipias e frustração ambiental, acarretando uma maior pressão psicológica, depreciando seu bem-estar, estando de acordo com resultados apontados por Vieuille-Thomas et al. (1995).

Em relação aos animais confinados em baias coletivas, estes apresentaram menor incidência de comportamentos resultantes do estresse ambiental, estereotipias e interações agressivas referentes ao estabelecimento de uma organização social. No entanto, a condição de alojamento ainda está aquém das necessidades das fêmeas gestantes, que apresentaram considerável freqüência de comportamentos anormais. 
Os dados de freqüência e porcentagem do tempo de observação comportamental apontam necessidades de melhorias para o T2, pois, apesar de melhor atender as exigências de bem-estar animal, ainda evidenciam-se problemas comportamentais, atribuídos principalmente ao manejo, como o regime de alimentação adotado e pela ausência de substrato no piso, utilização de cama (Lawrence et al., 1988).

A alteração destas rotinas de manejo poderiam elevar o bem-estar das matrizes alojadas em grupo, além de atender as normas da União Européia, melhorando a qualidade de vida dos animais, garantindo a diferenciação de seu produto.

\subsection{Lógica fuzzy aplicada às determinações de conforto para matrizes gestantes}

Para a variável temperatura $\left({ }^{\circ} \mathrm{C}\right)$, considerou-se o domínio do intervalo [7, 40], representando as faixas $<12,12-21,21-24,24-29$ e $>29$, pelos termos lingüísticos: muito baixo, baixo, médio, alto e muito alto, respectivamente (Tabela 4). A variável umidade relativa (\%) denota um domínio no intervalo [30, 100], representando as faixas $<70,70$ 80 e > 80, pelos termos lingüísticos: baixa, média e alta. As funções de pertinência selecionadas foram trapezoidais, usualmente utilizados em conjuntos nebulosos, possibilitando o aumento da sensibilidade na construção da base de regras (Sandri \& Correa, 1999).

Após a normalização em um universo de discurso padronizado, estes valores foram fuzificados, com a transformação das entradas em conjuntos nebulosos para que pudessem se tornar instâncias das variáveis lingüísticas. Com base nos dados apresentados neste trabalho, em relação aos limites de conforto ambiental, criou-se um cenário com os termos muito bom (MB), bom (B), regular $(R G)$ e ruim $(R M)$, que caracterizam uma base de regras com as definições de pertinência dos termos nebulosos, num domínio $[0,1]$. A base de regras é formada por estruturas do tipo: $s e<$ premissa $>\mathrm{e}$ $<$ premissa $>$ então $<$ conclusão $>$. Como por exemplo: se < umidade relativa é alta $>$ e $<$ temperatura é muito alta $>$ então $<$ conforto térmico é ruim $>$.

Estas regras, juntamente com os dados de entrada, foram processados pelo procedimento de inferências, o qual infere a ação de controle de acordo com o conforto 
térmico dos animais, aplicando o operador de implicação e verificando o grau de compatibilidade global entre os fatos e cláusulas nas premissas das regras, determinando o valor de conclusão, obtendo-se uma ação de controle geral.

Na Figura 33, observa-se a variação não-linear da condição de conforto térmico, como função da umidade relativa e da temperatura do ar, que foi gerada a partir da base de regras estabelecida. Desta forma, verifica-se que os valores de temperatura e umidade apresentam-se como resultado da inferência de um valor, no intervalo $[0,1]$, o que representa o conforto térmico das matrizes suínas. Neste contexto, foi possível obter uma saída do sistema de inferência, sob um dado ponto, para uma temperatura de 23,5 ${ }^{\circ} \mathrm{C}$ e umidade relativa de $65 \%$, e após a defuzificação, observar o índice para conforto térmico médio de 0,319 , de acordo com o gráfico de superfície.

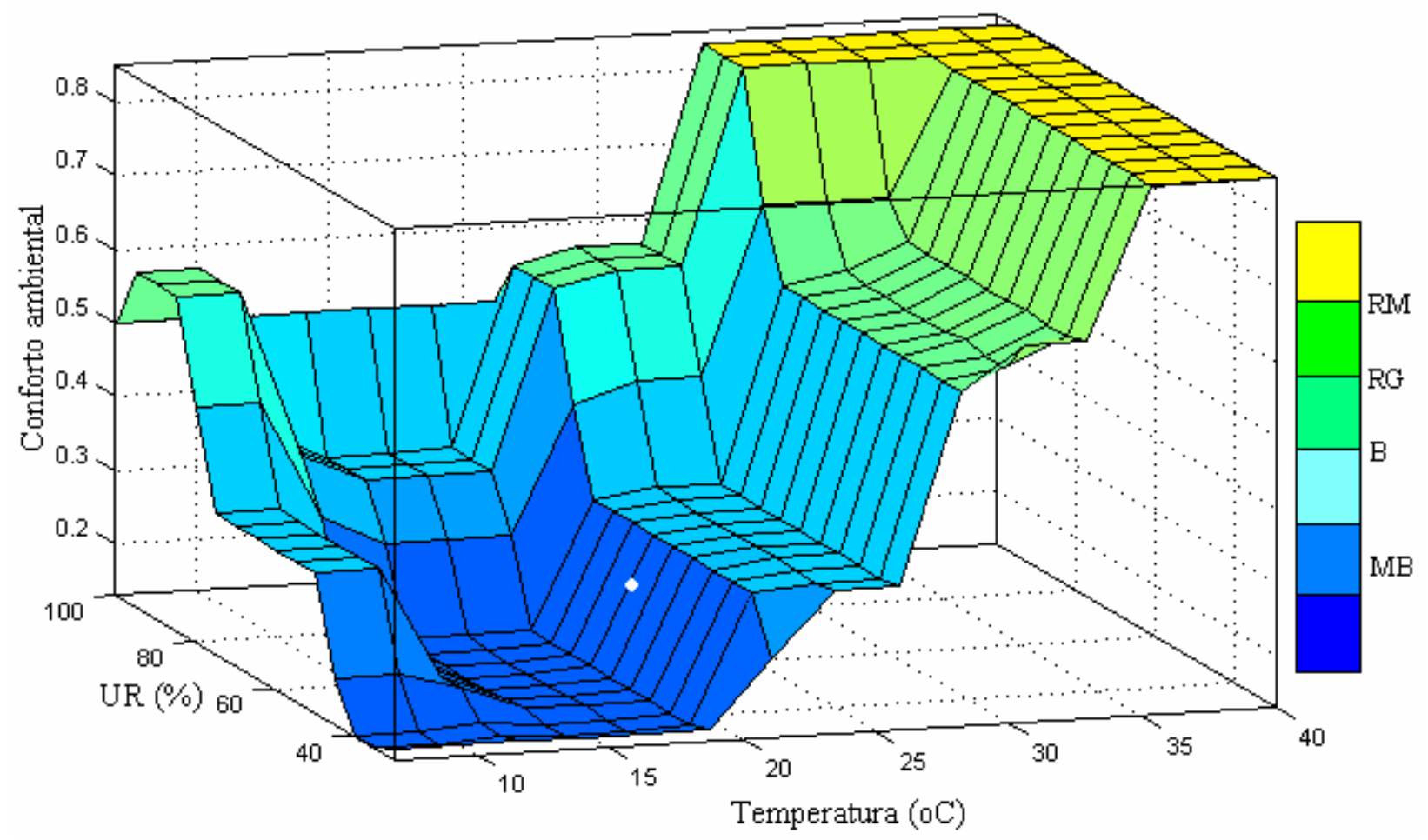

Figura 33 - Conforto ambiental como função da temperatura e umidade relativa do ar 
Considerando-se os dados médios registrados no interior da instalação, verifica-se que o valor encontrado para temperatura no $\mathrm{T} 1$ foi de $25,47{ }^{\circ} \mathrm{C}$ e umidade relativa do ar de 70,48\% (Tabela 9), permanecendo dentro da faixa limite estabelecida no sistema gerado, caracterizando-se como condição de conforto (B), não deslocando o índice de 0,319, a partir da base de regras estabelecidas, após sua verificação.

De maneira análoga, tem-se para a segunda situação, as variáveis temperatura e concentração de amônia, admitindo-se os termos lingüísticos de acordo com as faixas evidenciadas na Tabela 5. Para a variável temperatura, considerou-se o domínio [10, 40], em que foram atribuídas as denominações, muito baixo, baixo, médio, alto e muito alto. Já para a variável amônia, determinou-se o domínio [0, 15], com os termos lingüísticos muito baixo, baixo, médio e alto.

Nota-se na Figura 34, que variação não-linear da condição de conforto térmico, como função da concentração de amônia e da temperatura do ar, gerada a partir da base de regras estabelecidas, que os valores de temperatura e da concentração de amônia apresentam-se como resultado da inferência de um valor, no intervalo $[0,1]$, representando o conforto dos animais. Com base no gráfico de superfície a partir da informação gerada, foi possível obter uma saída do sistema de inferência, sob um dado ponto, para uma temperatura de $25{ }^{\circ} \mathrm{C}$ e um teor de amônia de $7,5 \mathrm{ppm}$, possibilitando estabelecer a condição limite de conforto das fêmeas gestantes, verificando-se uma condição média para o índice encontrado de 0,501. 


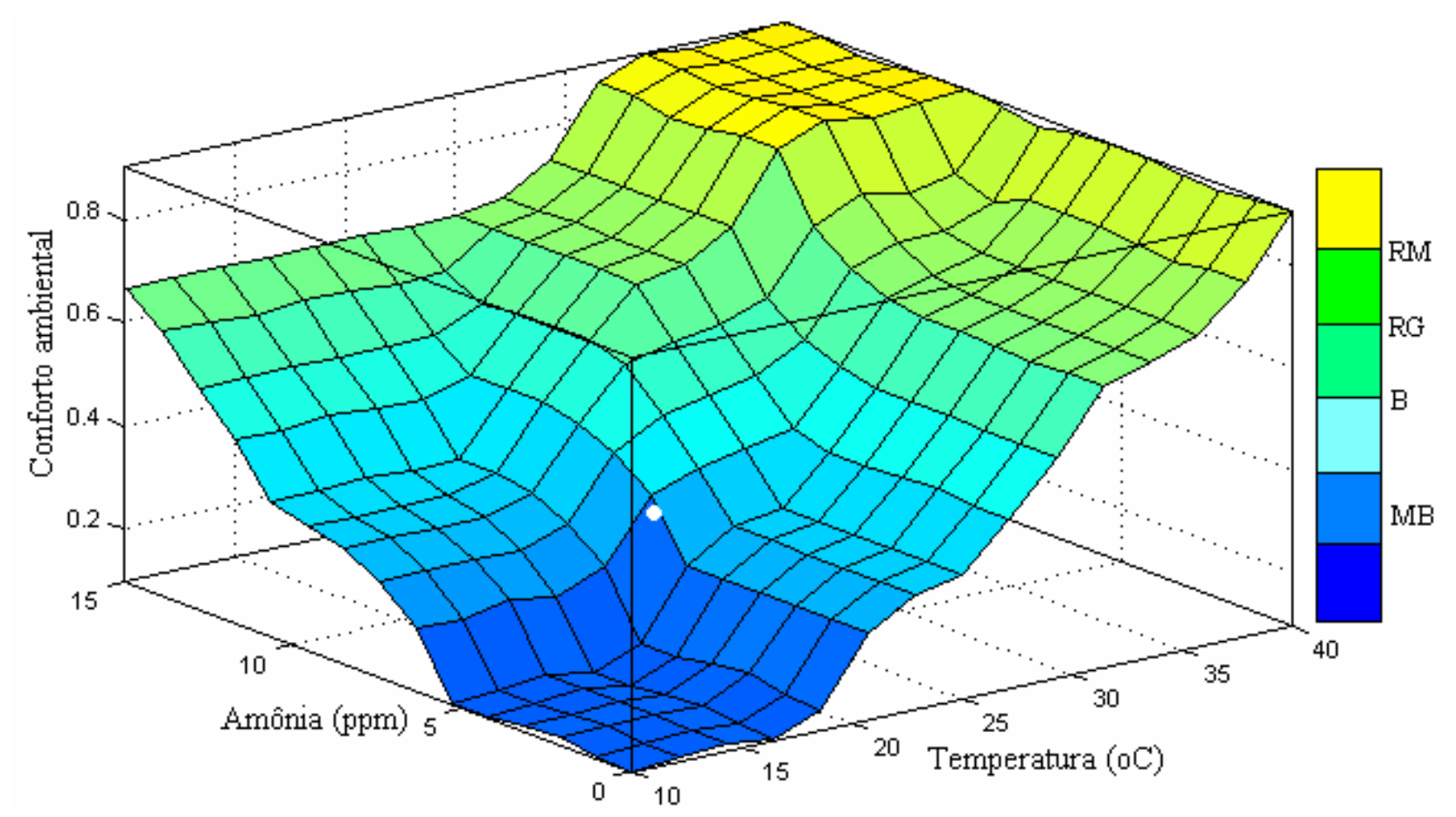

Figura 34 - Conforto ambiental como função da temperatura e a concentração de amônia

Verifica-se que as condições médias para temperatura $\left({ }^{\circ} \mathrm{C}\right)$ e o teor de amônia (ppm) registrados no interior da edificação apresentaram valores da ordem de 25,47 e 3,3 respectivamente, e de acordo com a Figura 35, observa-se que para estas condições sua classificação, comparativamente com o sistema gerado, encontra-se na faixa MB, a partir do índice de conforto ambiental de 0,336.

Outra simulação realizada foi para as variáveis independentes, temperatura e taxa respiratória, sendo definidas as variáveis lingüísticas em muito baixa, baixa, média, alta, muito alta e baixa, média, alta, muito alta, sob o domínio [10, 40] e [20, 80], respectivamente, de acordo com a Tabela 6.

A variável dependente caracterizada pelo conforto ambiental das matrizes em muito bom, bom, regular e ruim, no intervalo do domínio [0, 1], apresentou valores dentro da superfície gerada de $25{ }^{\circ} \mathrm{C}$ para temperatura e de 50 mov.min ${ }^{-1}$ para taxa respiratória, apresentando uma condição média de conforto de 0,718 , classificado como RG. As classificações foram formuladas com base nos dados registrados, podendo ser 
alteradas de acordo com o conhecimento de casos específicos localizados, visando à garantia da manutenção do controlador.

Sabendo-se que os valores médios para temperatura e taxa respiratória apresentaram valores de $25,47^{\circ} \mathrm{C}$ e 43 mov.min ${ }^{-1}$, para a condição mais crítica, com as matrizes alojadas em baias individuais, sua classificação apresenta um índice de conforto de 0,691 , ficando abaixo da condição imposta pelo sistema fuzzy, ficando entre B e RG.

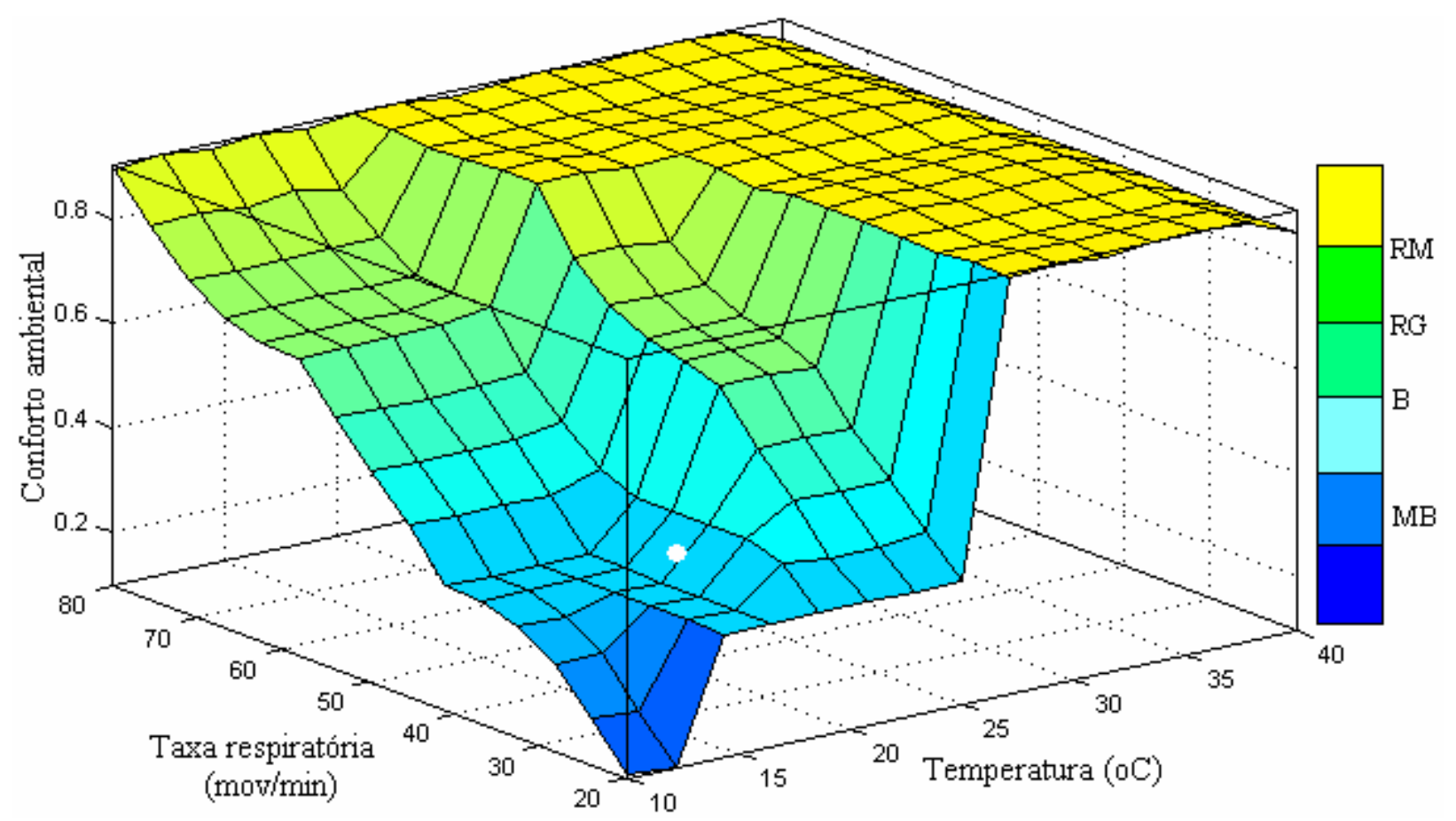

Figura 35 - Conforto ambiental como função da temperatura e a taxa respiratória

Para as variáveis independentes, entalpia (kJ.kg-1) e inatividade animal (\%), definiram-se os termos lingüísticos para simulação em baixa, média, alta, muito alta e muito baixa, baixa, média, alta, para entalpia e inatividade, respectivamente. Isto posto, e dados os valores de entalpia, sob o domínio $[50,90]$ representando as faixas $<60,60$ $70,70-80,>80$, e para inatividade animal, apresentando intervalo de domínio $[0,70]$ e faixas que variam $<15,15-45,45-65,>65$, de acordo com a Tabela 6 . 
Em relação aos limites de conforto térmico ambiental, criou-se um cenário com os termos muito bom, bom, regular e ruim, que caracteriza uma base de regras com as definições de pertinência dos termos nebulosos, num domínio $[0,1]$, baseando-se no conhecimento do especialista e com apoio da literatura, conforme apresentado na Tabela 7.

Os resultados possibilitaram uma saída do sistema de inferência, determinada a partir do estabelecimento de regras, que apontam condições médias de conforto aos animais para entalpia de $70 \mathrm{~kJ} \cdot \mathrm{kg}^{-1}$ e inatividade de $30 \%$, gerados a partir da defuzificação em que se encontra $\alpha=0,667$.

Diante dos valores médios registrados no T1, para entalpia $\left(\mathrm{kJ} \mathrm{kg}^{-1}\right)$ e inatividade animal (\%) foram de 63,47 e 30,9\% respectivamente. Ficando dentro dos limites estabelecidos pelo sistema entre B e RG.

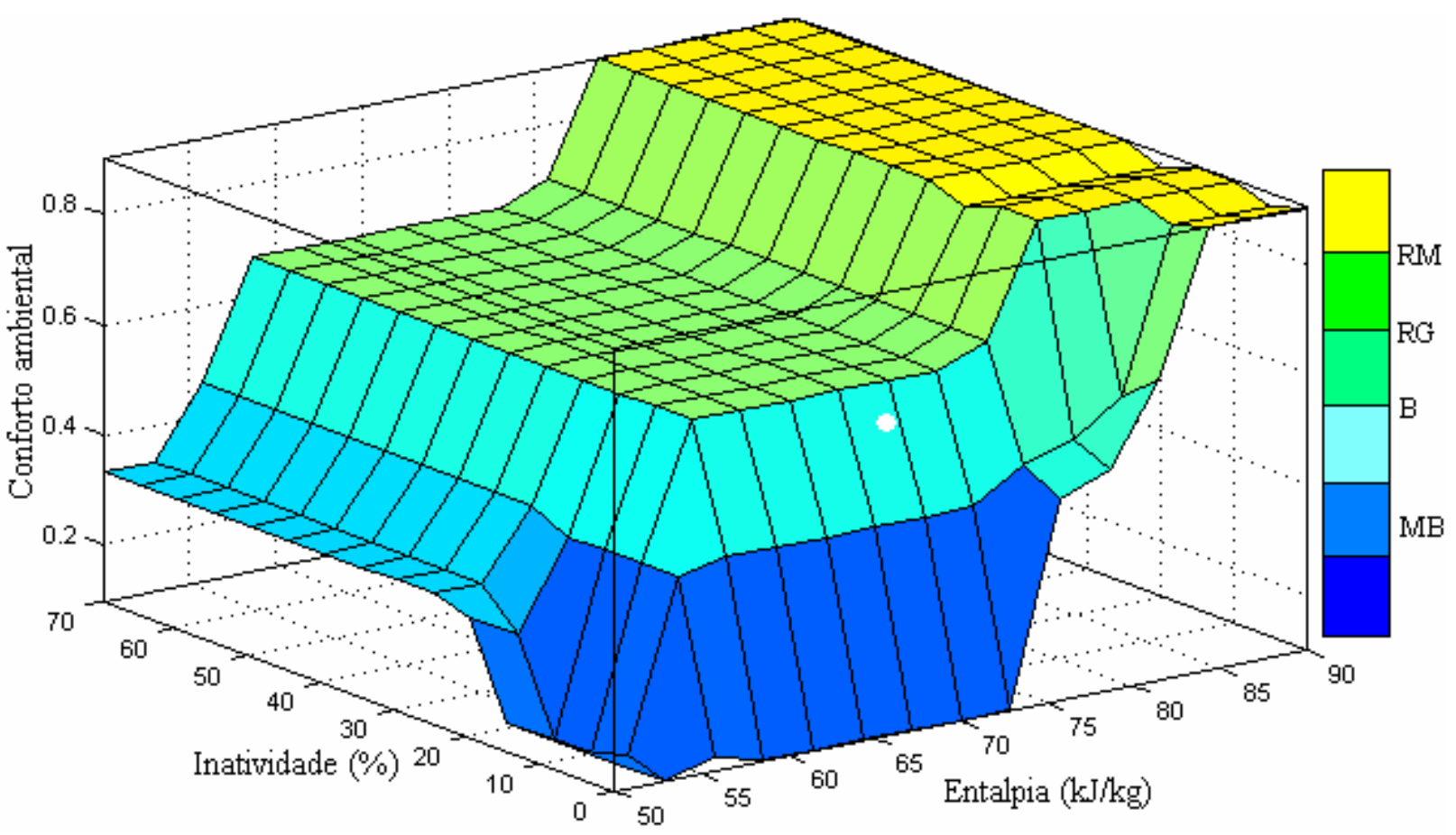

Figura 36 - Conforto ambiental como função da entalpia $\left(\mathrm{kJ} \mathrm{kg}^{-1}\right)$ e da inatividade animal $(\%)$ 
As técnicas de controle fuzzy, ao contrário dos controladores convencionais, em que o algoritmo de controle é descrito analiticamente por equações algébricas ou diferenciais, através de um modelo matemático, utilizam regras lógicas no algoritmo de controle, com a intenção de descrever numa rotina a experiência humana, intuição e heurística para controlar um processo, auxiliando no suporte a tomada de decisão no controle dos atuadores, garantindo, assim, uma melhor eficiência dos sistemas de climatização e sucesso na produção.

Os controladores nebulosos são robustos e de grande adaptabilidade, incorporando conhecimento que outros sistemas nem sempre conseguem acomodar. Também são versáteis, principalmente quando o modelo físico é complexo e de difícil representação matemática.

Em geral, os controladores nebulosos encontram maior utilidade em sistemas nãolineares, sendo capazes de superar perturbações e plantas com níveis de ruídos. Além disso, mesmo sistemas em que a incerteza se faz presente de maneira intrínseca, agregam uma robustez característica. No entanto, provar determinadas propriedades de robustez é uma tarefa difícil neste tipo de abordagem.

Neste contexto, a utilização da ferramenta permitiu estabelecer alguns parâmetros ideais de conforto às matrizes gestantes, conforme apresentado na Tabela 15.

Tabela 15. Limite médio do conforto ambiental para matrizes gestantes determinados por meio da teoria dos conjuntos fuzzy e os valores médios registrados no estudo

\begin{tabular}{|c|c|c|c|c|}
\hline Variáveis independentes & $\begin{array}{l}\text { Conforto } \\
\text { ambiental }\end{array}$ & $\begin{array}{l}\text { Valores } \\
\text { médios }\end{array}$ & $\begin{array}{l}\text { Variável } \\
\text { dependente } \\
(\alpha)\end{array}$ & $\begin{array}{c}\text { Variável } \\
\text { dependente }\left(\alpha^{\prime}\right)\end{array}$ \\
\hline Temperatura $\left({ }^{\circ} \mathrm{C}\right)$ & 24,25 & 25,47 & 0,319 & 0,319 \\
\hline Umidade relativa $(\%)$ & 65 & 70,48 & - & - \\
\hline Entalpia $\left(\mathrm{kJ}^{\mathrm{k}} \cdot \mathrm{kg}^{-1}\right)$ & 70 & 63,47 & 0,667 & 0,667 \\
\hline Amônia (ppm) & 10 & 3,3 & 0,501 & 0,336 \\
\hline $\begin{array}{l}\text { Taxa respiratória } \\
\left(\mathrm{mov} \cdot \mathrm{min}^{-1}\right)\end{array}$ & 50 & 43 & 0,718 & 0,691 \\
\hline Inatividade animal $(\%)$ & 30 & 30,9 & - & - \\
\hline
\end{tabular}


É interessante salientar, que o sistema fuzzy permitiu estabelecer os valores médios para os índices de conforto ambiental $(\alpha)$, e posteriormente a caracterização das variáveis registradas no sistema de produção estudado ( $\left.\alpha^{\prime}\right)$, o que possibilitou a comparação entre os índices sugeridos e encontrados no experimento, permitindo um melhor controle do ambiente no interior da instalação.

$\mathrm{O}$ uso da teoria dos conjuntos fuzzy é de interesse e utilidade para a continuidade de pesquisas desta natureza, pois permitiu que se fizesse uma alusão entre os dados resultantes do trabalho experimental com os estabelecidos pela literatura, por intermédio de uma base de regras estabelecidas, para a determinação do conforto ambiental aplicado a matrizes na fase de gestação (Pedryez e Gomide, 1998; Barros \& Bassanezi, 2001).

\subsubsection{Uso da rede neural artificial para predição dos índices zootécnicos}

Um dos problemas enfrentados no treinamento de redes neurais tipo Multi Layer Perceptron (MLP) com treinamento backpropagation diz respeito à definição de seus parâmetros. A seleção dos parâmetros de treinamento do algoritmo é um processo que demanda grande esforço, pois pequenas diferenças nestes parâmetros podem levar a grandes diferenças, tanto no tempo de treinamento como na generalização obtida.

O parâmetro taxa de aprendizado tem grande influência durante o processo de treinamento da rede neural. Uma taxa de aprendizado muito baixa torna o aprendizado da rede muito lento, ao passo que uma taxa de aprendizado muito alta provoca oscilações no treinamento e impede a convergência do processo de aprendizado. Geralmente seu valor varia de 0,1 a 1,0. No entanto, para efeito de treinamento da rede em questão, adotou-se o valor pré-fixado de 0,1 , haja vista que valores superiores a este não permitiram convergência do processo na superfície do erro médio quadrático.

O critério adotado para parada do treinamento foi definido por uma combinação de métodos, pelo erro e pelo número de ciclos (epochs), encerrando-se o treinamento quando um dos critérios foi atendido. Desta forma, o treinamento foi encerrado quando houve convergência na superfície do erro médio quadrático, em que se adotou o valor de 0,005 , após inúmeros ajustes em função do resultado, atingindo uma boa generalização a 
524 ciclos, isto é, o número de vezes em que o conjunto de treinamento foi apresentado à rede.

Com relação ao número de neurônios na camada escondida, estes foram definidos empiricamente. Após inúmeras tentativas, encontrou-se um valor de 25 neurônios, o que permitiu extrair as características gerais do conjunto de dados para uma boa generalização, encontrando uma representação ótima da saída, depois de seu treinamento.

Após os estímulos de entrada serem processados pela função de ativação, o estado de ativação é passado para a função de propagação que produz o valor de saída do neurônio. A função matemática de mapeamento do neurônio, chamada de função de transferência, é constituída pela composição das funções de propagação e de ativação, em que se considerou a função tangente sigmoidal, para camada oculta e de saída.

$\mathrm{O}$ conjunto de treinamento foi apresentado à rede neural para que o algoritmo backpropagation atuasse, adotando-se 0,005 como valor do erro médio quadrático para que o algoritmo alcançasse. Isto significa que o algoritmo realizou várias interações de atualização dos pesos até atingir este valor de erro. Na Figura 37 verifica-se o gráfico de busca do vetor gradiente na superfície de erro.

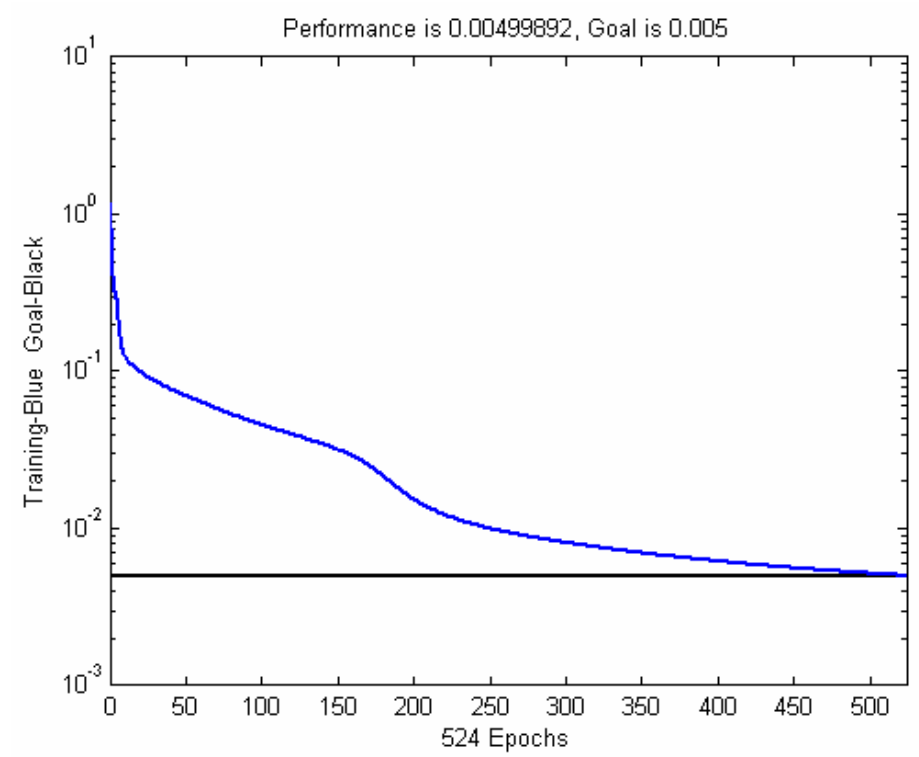

Figura 37 - Gráfico do andamento do treinamento da rede 
O treinamento procedeu sem problemas, e a rede conseguiu convergir para o valor do erro determinado. Alguns parâmetros do algoritmo backpropagation utilizados para treinar esta rede são descritos na Tabela 8 .

As previsões giram em torno de um valor médio capaz de simular os picos dos eventos. O modelo de previsão, portanto, consegue explicar a variação do peso no nascimento dos leitões, tendo em vista o alto valor encontrado para o coeficiente de determinação $\mathrm{R}^{2}=0,9389$ (Figura 38a).
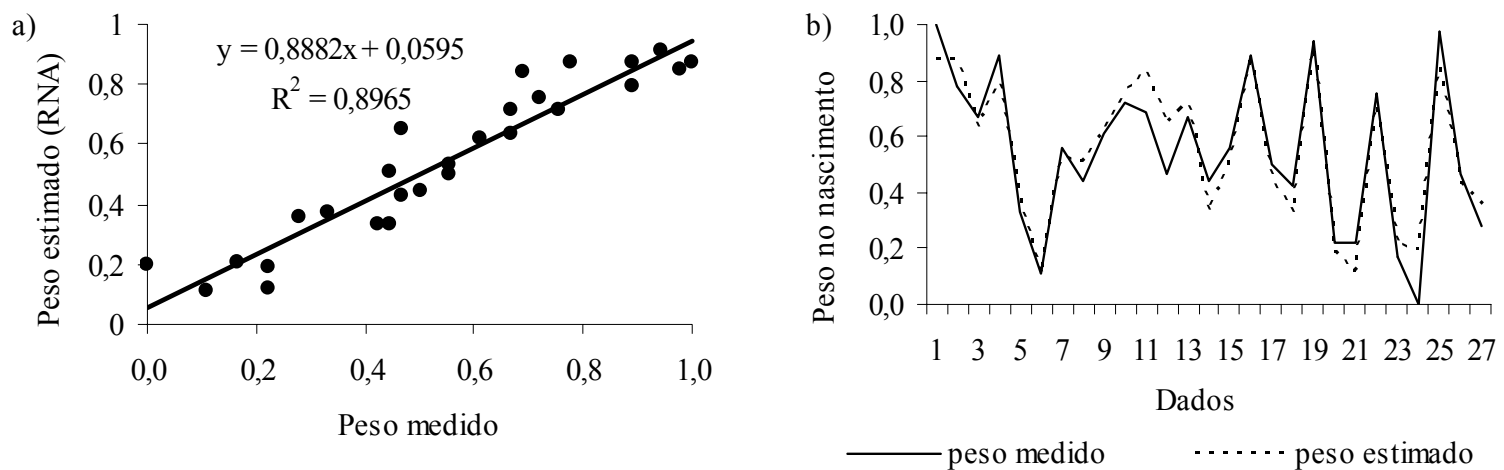

Figura 38 - Relação funcional entre os dados normalizados para o peso no nascimento dos leitões medidos e os dados normalizados para o peso no nascimento estimado pela RNA (a) e sua variação na fase de teste e validação (b)

Como considerações gerais extraídas dos resultados dos testes, pode-se dizer que as aproximações dos valores estimados pela rede apresentaram uma ótima caracterização dos dados reais, registrados "in loco" no decorrer do período experimental, percebendose somente alguns pontos isolados em que houve uma pequena tendência a subestimar valores altos ou superestimar valores baixos (Figura 38b).

Os pares de entradas e saídas possibilitaram uma verificação da evolução do aprendizado por meio da comparação entre a saída desejada e a real. As predições conseguem simular o número de leitões mumificados com base nas variáveis de entrada, tendo em vista o valor encontrado para o coeficiente de determinação $\mathrm{R}^{2}=0,9508$ (Figura $39 a)$. 

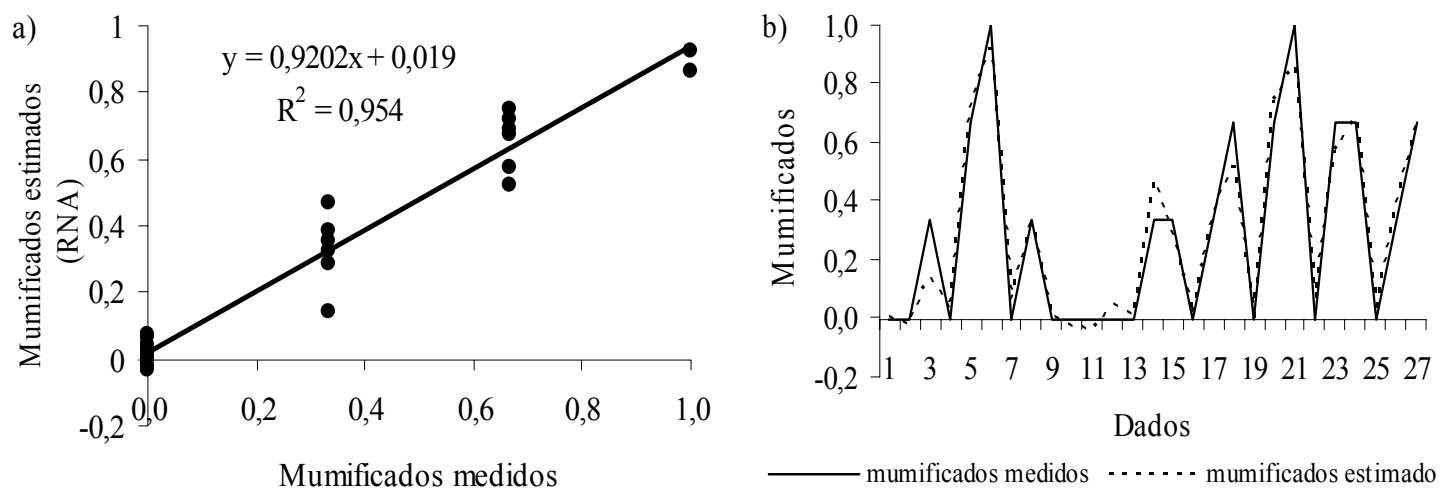

Figura 39 - Relação funcional dos dados normalizados para o número de leitões mumificados medidos e os dados normalizados para o número de mumificados estimados pela RNA (a) e sua variação na fase de teste e validação (b)

A variação do número de leitões mumificados reais e estimados mostrou valores semelhantes, apresentando ótima generalização dos dados medidos, verificando-se alguns pontos isolados o mesmo perfil de variação observado para a variável peso no nascimento, em que denota uma pequena tendência a subestimar valores altos ou superestimar valores baixos (Figura 39b).

O sucesso das redes neurais está diretamente relacionado com a sua alta versatilidade, pois existem aplicações para as mais diversas áreas, e isto faz delas uma tecnologia bastante promissora para o desenvolvimento de aplicações na agropecuária.

O problema de aproximação proposta neste trabalho serviu para demonstrar a viabilidade de utilização de RNAs para a previsão dos índices zootécnicos (peso no nascimento dos leitões, número de leitões mumificados) com base nas variáveis, temperatura do ar e taxa respiratória das fêmeas gestantes, como representação da condição de conforto e bem-estar animal. É importante ressaltar que outras arquiteturas de rede ou outros parâmetros também podem ser aplicados para situações semelhantes e que a solução proposta neste trabalho foi escolhida com o objetivo de apresentar o potencial de aplicação da ferramenta e seu bom desempenho neste tipo de problema. 


\section{CONCLUSÕES}

De acordo com os resultados obtidos nesta pesquisa, pode-se concluir que:

- em relação aos sistemas de alojamento para matrizes gestantes, aquele que se mostrou mais adequado às condições de conforto e bem-estar animal foi o confinamento em baias coletivas, atendendo as exigências internacionais e a demanda animal por um ambiente que lhe garanta maior liberdade de movimentação, conforto térmico ambiental, potencializando o efeito de sua expressão produtiva;

- as variáveis meteorológicas e ambientais apontam o sistema de confinamento em baias coletivas como aquele que permitiu melhor condicionamento térmico natural às matrizes em gestação, considerando-se sua localização no interior da edificação que potencializava as trocas convectivas de calor por meio da ventilação natural e pelo fato de dispor de maior área por animal. Com relação à qualidade química do ar, os teores médios para os gases registrados no interior da instalação, na maior parte do tempo, não superaram os valores considerados críticos para matrizes em fase de gestação;

- referindo-se aos animais confinados em baias coletivas, estes apresentaram menor incidência de comportamentos resultantes do estresse ambiental, estereotipias e interações agressivas referente ao estabelecimento de uma organização social, comparativamente às baias individuais; 
- os parâmetros fisiológicos e os índices zootécnicos apresentaram valores mais adequados para o tratamento baias coletivas, assim como seu reflexo no desempenho da parição dos leitões provenientes das matrizes submetidas a esse tratamento;

- a utilização da teoria dos conjuntos fuzzy aplicada a produção animal, permitiu estabelecer condições de contorno para delinear o conforto e o bem-estar das matrizes gestantes, possibilitando um classificação geral do sistema de produção;

- o uso de RNAs serviu para demonstrar a viabilidade de utilização da ferramenta, apresentando alta eficiência na predição dos índices zootécnicos (peso no nascimento dos leitões, número de leitões mumificados) com base nas variáveis, temperatura do ar e taxa respiratória das fêmeas gestantes. 


\section{REFERÊNCIAS BIBLIOGRÁFICAS}

AARNINK, A.J.A.; ELZING, A. Dynamic model for ammonia volatilization in housing with partially slatted floors, for fattening pigs. Livestock Production Science, v.53, p.153-169, 1998.

ALBRIGHT, L.D. Environment control for animals and plants. St. Joseph: American Society of Agricultural Engineers Michigan, 1990. 453p. (ASAE Textbook, 4).

ALENCAR M.C.B.; GONTIJO L.A.; NÄÄS, I.A; BARACHO, M.S.; MIRAGLIOTTA, M.Y. A saúde ocupacional na produção de frangos de corte no brasil: será que sabemos o bastante? In: SEMINÁRIO POLUENTES AÉREOS E RUÍDOS EM INSTALAÇÕES PARA PRODUÇÃO DE ANIMAIS, Campinas, 2002. Anais. Campinas: FEAGRI, 2002. p.57-62.

ALTROCK, C.V. Fuzzy logic \& neurofuzzy applications explained. Prentice Hall: New Jersey, 1995. 327p.

AMENDOLA, M.; CASTANHO, M.J.; NÄÄS, I.A.; SOUZA, A.L. Análise matemática de condições de conforto térmico para avicultura usando a teoria dos conjuntos fuzzy. Biomatemática, v.14, n.1, p.87-92, 2004.

AMERICAN SOCIETY OF HEATING AND REFRIGERATION AND AIR CONDITIONED ENGINEERS. Environment: handbook of funtamentals. New York: ASAE, 1983. p.139-198.

ANDERSON, B.E. Regulação da temperatura e fisiologia ambiental. In: SWENSON, M.J. Dukes' fisiologia dos animais domésticos. 10. ed. , Rio de Janeiro: Guanabara Koogan, 1988, p.722-735.

ANDRADE, M.T.C. A técnica da lógica fuzzy aplicada ao controle automáticos de processos em plantas químicas industriais. In: CONGRESSO DE EQUIPAMENTOS E AUTOMAÇÃO DA INDUSTRIA QUÍMICA E PETROQUÍMICA, 3., São Paulo, 1997. Resumos. São Paulo, 1997. p.72.

ANIL, L.; ANIL, S.S.; DEEN, J. Relationship between postural behaviour and gestation stall dimensions in relation to sow size. Applied Animal Behaviour Science, v. 77, n.3, p.173-181, 2002.

ANUALPEC 2004. Anuário da pecuária brasileira. São Paulo: FNP, Consultoria e Agroinformativo, 2004. p.267-299. 
APPLEBY, M.C.; HUGHES, O.; ELSON, H.A. Poultry production systems behavior, management and welfare. Wallingford, CAB International, 1992. 238p.

AREY, D.S. Time course for the formation and disruption of social organisation in group-housed sows. Applied Animal Behaviour Science, v.62, n.2-3, p.199-207, 1999.

AREY, D.S.; EDWARDS, S.A. Factors influencing aggression between sows after mixing and the consequences for welfare and production. Livestock Production Science, v. 56,n.1, p. 61-70, 1998.

AREY, D.S.; FRANKLIN, M.F. Effects of straw and unfamiliarity on fighting between newly mixed growing pigs, Applied Animal Behaviour Science, v. 45, n.1, p. 2330, 1995.

AREY, D.S.; SANCHA, E.S. Behaviour and productivity of sows and piglets in a family system or in farrowing crates. Applied Animal Behaviour Science, v.50, n.2, p.135$145,1996$.

ASTION, M.; WILDING, P. The aplication of backpropagation neural networks to porblems in pathology and laboratory medicine. Archive Pathology Laboratory Medicine, v.116, p.995-1001, 1992.

BALDWIN, B.A. Operant studies on the behaviou of pigs and sheep in relation to the physical environment. Journal of Animal Science, v.49, n. 4, p.1125-1127. 1979.

BARB, C.R.; ESTIENNE, M.J.; KRAELING, R.R.; MARPLE, D.N.; RAMPACEK, G.B.; RAHE, C.H.; SARTIN, J.L. Endocrine changes in sows exposed to elevated ambient temperature during lactation. Domestic Animal Endocrinology, v.8, p.117$1127,1991$.

BARKER, J.; CURTIS, S.; HOGSETT, O.; HUMENIK, F. Waste quality \& waste management: safety in swine productions systems. North Carolina: Cooperative Extension Service, 2002. 6p.

BARNETT, J.L.; HEMSWORTH, P.H. The validity of physiological and behavioural measures of animal welfare. Applied Animal Behaviour Science, v.1, p.177-187, 1990.

BARNETT, J.L.; CRONIN, G.M.; MCCALLUM, T.H.; NEWMAN, E.A.; HENNESSY, D.P. Effects of grouping unfamiliar adult pigs after dark, after treatment with amperozide and by using pens with stalls, on aggression, skin lesions and plasma cortisol concentrations. Applied Animal Behaviour Science, v.50, n.1, p. 121-133, 1996.

BARNETT, J.L.; HEMSWORTH, P.H.; CRONIN, G.M.; NEWMAN, E.A.; MCCALLUM, T.H.; CHILTON, D. Effects of pen size, partial stalls and method of feeding on welfare-related behavioural and physiological responses of group-housed pigs. Applied Animal Behaviour Science, v.34, n.1, p. 207-220, 1992. 
BARROS, L.S.; BASSANEZI, R.C. Introdução à teoria dos conjuntos fuzzy: aplicações em biomatemática. In: CONGRESSO LATINO AMERICANO DE BIOMATEMÁTICA, Campinas, 2001. Notas de mini-curso. Campinas: FEAGRI, 2001. p.54-72.

BAUER, J.; HOY, S. Zur häufigkeit von rangordnungskämpfen beim ersten und wiederholten zusammentreffen von sauen zur gruppenbildung. KTBL-Schrift, v.418, p. 181-187, 2002.

BAXTER, M.R.; SCHWALLER, C.E. Space requirements for sows in confinement. In: BAXTER, S.H.; BAXTER, M.R.; MACCORMACK, J.A.D. (Ed.). Farm animal housing and welfare. The Hague: Martinus Nijhoff, 1983. p.181-195.

BENEDI, J.M.H. El ambiente de los alojamientos ganaderos. Hojas Divulgadoras, n.6, p.1-28, 1986.

BOKMA, S. Housing and management of dry sows in groups in practice: partly slatted systems. In: INTERNATIONAL SYMPOSIUM ON ELECTRONIC IDENTIFICATION IN PIG PRODUCTION, Stoneleigh, 1990. Proceedings. Stoneleigh: RASE, 1990. p.37-45.

BORTOLOZZO, F.P.; WENTZ, I.; BRANDT, G.; NOBRE Jr., A. Influência da temperatura corporal sobre a eficiência reprodutiva em fêmeas suínas. In: CONGRESSO BRASILEIRO DE VETERINÁRIOS ESPECIALISTAS EM SUÍNOS, Foz do Iguaçu, 1997. Anais. Foz do Iguaçu: Abraves, 1997. p.281-282.

BRANDT, G.; WENTZ, I.; BORTOLOZZO, F.P.; GUIDONI, A.L. Influência da temperatura corporal sobre a eficiência reprodutiva de fêmeas suínas. In: CONGRESSO BRASILEIRO DE VETERINÁRIOS ESPECIALISTAS EM SUÍNOS, Blumenau, 1995. Anais. Blumenau: Abraves, 1995. p.129.

BROOM, D. M. Animal welfare: concepts and measurement. Journal of Animal Science, v.69, n.10, p.4167-4175, 1991.

BROWN-BRANDL, T.M.; EIGENGERG, R.A.; NIENABER, J.A.; KACHMAN, S.D. Thermoregulatory profile of a newer genetic line of pigs. Livestock Production Science, v.71, p.253-260, 2001.

BRUCE, JM. Ventilation and temperature control criteria for pigs. In: CLARK, J.A. Environmental aspect of housing for animal production. London: Butterworths, 1981. p.197-216.

BUFFINGTON, D.E.; COLAZZO-AROCHO, A.; CATON, G.H. Black globe humidity comfort index (BGHI) as comfort equation for dairy cows. Transaction of the ASAE, v.24, n.4, p.711-714, 1981.

CADENAS, J.M.; PELTA, D.A.; PELTA, H.R.; VERDEGAY, J. L. Application of Fuzzy optimization to diet problems in Argentinean farms. European Journal of Operational Reseach, v.1, n.5, p.10-12, 2003. 
CAVALCANTI, S.S.; BARBOSA, A.S.; SAMPAIO, I.B.M. Efeito da duração do parto na incidência de leitões natimortos. Arquivos da Escola de Veterinária da UFMG, v.3, n.1, p.9-43, 1979.

CHANG, C.W.; CHUNG, H.; HUANG, C.F.; SU, H.J.J. Exposure assessment to airbone endotoxin, dust, ammonia, hydrogen sulfide and carbon dioxide in open style swine houses. Annals of Occupational Hygiene, v.45, n.6, p.457-465, 2001.

CHEVILLON, P. O bem estar dos suínos. http://www.embrapa.gov.br. (10 maio 2000).

CLARK, L.K.; LEMAN, A.D. Factors that influence litter size in pigs: Part 1. Pig News and Information, v.7, p.303-310, 1986.

COMMISSION INTERNATIONALE DU GÉNIE RURAL. Aerial environment in animal housing: concentration in and emission from farm buildings. Dublin, 1994. $116 \mathrm{p}$.

CORNELISSEN, A.M.G.; BERG, J.; KOOPS, W.J; KAYMAK, U. Elicitation of expert knowledge for fuzzy evaluation of agricultural production systems. Agriculture Ecosystems and Environment, v.1, n.1, p 1-18, 2002.

COX, S. W. R. Farm electronics. Oxford: BSP Professional Books, 1988. 156p.

CRONIN, G.M.; WIEPKEMA, P.R. An analysis of stereotyped behaviour in tethered sows. Annales de Recherches Veterinaires, v.15, n.1, p.263-70, 1984.

CURTIS, S.E.; BACKSTROM, L. Housing and environmental: Influences on production. In: LEMANN, A..D.; STRAW, B.E.; ,MENGELING, W.L., D'ALLAIRE, S.; TAYLOR, D.L. Disease of swine. 7.ed. Ames: The Iowa State University, 1992. p.884-900.

CVETICANIN, D. New approach to the dynamic weighing of livestock. Biosystems Engineering, v.86, n.2, p.247-25, 2003.

DALLA-COSTA, O.A., SILVA, R.A.M.S., SANTOS, T.S., SEVERO, D.C., MESQUITA, F.S., ALESSANDRI, A.M.M., DORNELES, L.S., ZANELLA, E.L. e COLDEBELLA, A.. A comparison of the maternal behaviour of sows in confined and outdoor systems. In: INTERNATIONAL CONGRESS ISAE, 34., Madri, 2000. Proceedings. Madri: ISAE, 2000. p.126.

DAMM, B.I., PEDERSEN, L.J., MARCHANT, J.N. E JENSEN, K.H. The presence of a farrowing nest affects gilt responsiveness to neonatal piglets and interval from birth to first suckle. In: INTERNATIONAL CONGRESS ISAE, 34., Madri, 2000. Proceedings. Madri: ISAE, 2000. p.127.

DE LEEUW, J.A.; EKKEL, E.D.; JONGBLOED, A.W.; VERSTEGEN, M.A.W. Effects of floor-feeding and the presence of a foraging substrate on the behaviour and stress physiological response of individually housed gilts. Applied Animal Behaviour Science, v.80, n.2, p. 297-310, 2003.

DEATON, J.W. Environmental factor involved in growth and development In: World animal Science- Poultry Science, v.9, n.1, p.135-142, 1995. 
DIVIDICH, J.; RINALDO, D. Effects de l'environment thérmique sur les performance du porc en croissance. Journée de la Recherche Porcine en France, v.21, n.2, p.219-230, 1989.

DONHAM, K. A historical overview of research on the hazards of dust in livestock buildings. In: INTERNATIONAL SYMPOSIUM ON DUST CONTROL IN ANIMAL PRODUCTION FACILITIES, 30., Aahus, 1999. Proceedings. Horsens: Danish Institute of Agricultural Sciences, 1999. p.13-21.

DURREL, J.L.; BEATTIE, V.E.; SNEDDON, I.A.; KILPATRICK, D. Pre-mixing as a technique for facilitating subgroup formation and reducing sow aggression in large dynamic groups. Applied Animal Behaviour Science, v.84, n.2, p.89-99, 2003.

DUSENBERY, D.B. Using a microcomputer and video camera to simultaneously track 25 animals. Computer Biological Medicine Veterinary, v.15, n.4, p.169-175, 1985.

ESMAY, M.L. Principles of animal environment. West Port CT: ABI, 1982. 325p.

EWBANK, S.A.; MEESE, G.B. Aggressive behaviour in groups of domesticated pigs on removal and return of individuals. Animal Production, v.13, p.685-693, 1971.

FIALHO, F.B. Modernização no controle da produção de suínos: zootecnia de precisão. In: SILVA, I.J.O. Ambiência e qualidade na produção industrial de suínos. Piracicaba: FEALQ, 1999. p.131-148.

FIRK, R.; STAMER, E.; JUNGE, W.; KRIETER, J. Improving oestrus detection by combination of activities measurementes with information about previous oestrus cases. Livestock Production Sciences, v.82, n.1, p. 97-103, 2003.

FLORES, B.; CANTLEY, T.C.; MARTIN, M.J.; DAY, B.N. Effect of elevated ambient temperatures on puberty in gilts. Journal of Animal Science, v.67, p.779-784, 1989.

FONDA, E.S. The effect of heat on reproductive fertility in the sows and gilts. Livestock Production, v.18, p.32-36, 1978.

FORSSTRÖM, J.J.; DALTON, K.J. Artificial neural networks for decision support in clinical medicine. Annals of Medicine, v.27, n.5, p.509-517, 1995.

FRASER, D. The effect of straw on the behaviour of sows in tether stalls. Animal Production, v.1, n.1, p. 59-68, 1975.

FRASER, D. Animal ethics and animal welfare science: bridging the two cultures. Applied Animal Behaviour Science, v.65, n.1, p.171-189, 1999.

FRASER, A. F.; BROOM, D. M. Farm animal behaviour and welfare. 3. ed. London: Baillière Tindall, 1990. 437p.

FRASER, D.; RITCHIE, J.S.D.; FRASER, A.F. The term "stress" in a veterinary context. British Veterinary Journal, v.13, n.1, p.653-662, 1975.

FRIEND, D.W.; CUNNINGHAM, H.M.; NICHOLSON, J.W.G. The duration of farrowing in relation to the reproductive performance of Yorkshire sows. Canadian Journal of Medicine Science, v.26, n.6, p.127-130, 1962. 
GOMIDE, F.A.; GUDWIN, R.R.; TANSCHEIT, R. Conceitos fundamentais da teoria de conjuntos fuzzy lógica e aplicações. In: INTERNATIONAL FUZZY SYSTEMS ASSOCIATION WORLD CONGRESS, 6, Campinas, 1995. Resumos. Campinas: IFSA, 1995. p.1-38.

GONYOU, H.W. Design criteria: Should freedom of movement be retained?. Acta Agricultural Scandinavia, Sect. A, Animal Science, n. 27, Suppl. 1, p. 36-39, 1996.

GORDON, W.A.M. Environmental studies in pig-housing. Ventilation and its measurement. British Veterinary Journal, v.118, p.171-205, 1962.

GUSTAFSSON, M.; JENSEN, P; DE JONGE, F.H.; SCHUURMAN, T. Domestication effects on foraging strategies in pigs (Sus scrofa). Applied Animal Behaviour Science, v.62, n.1, p.305-317, 1999.

HAHN, G.L.; NIENABER, J.A.; DESHAZER, J.A. Air temperature influences on swine performance and behavior. Applied Engineerning in Agriculture, v.3, n.2, p.295$302,1987$.

HANNAS, M.I.; OLIVEIRA, R.F.M.; DONZELE, J.L.; FERREIRA, A.S.; BARBOSA, R.B.; FERREIRA, R.A.; MORETI, A.M. Efeito da temperatura ambiente sobre os parâmetros fisiológicos e hormonais de leitões dos 15 aos $30 \mathrm{~kg}$, (compact disc). In: REUNIÃO ANUAL DA SOCIEDADE BRASILEIRA DE ZOOTECNIA, 36., Porto Alegre, 1999. Porto Alegre: SBZ, 1999.

HANSEN, L.L.; VESTERGAARD, K. Tethered versus loose sows: ethological observations and measures of productivity: 2. Production results. Annales de Recherches Veterinaires, v.15, pp. 185-191, 1984.

HAYKIN, S. Redes neurais: princípios e práticas. 2.ed. Porto Alegre: Bookman, 2001. 900 p.

HEITMAN Jr., H.; HUGHES, H.E. Effects of elevated ambient temperature on pregnant sows. Journal of Animal Science, v.10, n.4, p.907-915, 1951.

HEMSWORTH, P.H.; BARNETT, J.L.; HANSEN, C.; WINFIELD, C.G. Effect of social environmental on welfare status and sexual behaviour of female pigs. II Effects of space allowance. Applied Animal Behaviour Science, v.16, p.259-267, 1986.

HOFF, S.J. A quasi ad-libitum eletronic feeding system for gestating sows in loose housing. Computers and Eletronics in Agriculture, v.19, n.3, p.277-288, 1998.

JENSEN, K.H.; PEDERSEN, B.K.; PEDERSEN, L.J.; JORGENSEN, E. Well-being in pregnant sows: confinement versus group housing with electronic sow feeding. Acta Agricultural Scandinavia, v.45, n.1, p.266-275, 1995.

JORNAL OFICIAL DAS COMUNIDADES EUROPÉIAS. Directivas da CEE. http://www.europa.eu.int/eur-lex/pri/pt/oj/dat/2001/1_316/1_31620011201 pt00360038.pdf. (12 maio 2004). 
KOERKAMP, G.P.W.G.; METZ, J.J.M.; UENK, G.H.; PHILLIPS, V.R.; HOLDEN, M.R.; SNEATH, R.W.; SHORT, J.L.; WHITE, R.P.; HARTUNG, J.; SEEDORF, J.; SCHRÖDER, M.; LINKERT, K.H.; PEDERSEN, S.; TAKAI, H.; JOHNSEN, J.O.; WATHES, C.M. Concentrations and emissions of ammonia in livestock buildings in northern Europe. Journal of Agricultural Engineering Research, v.70, n.1, p.7995, 1998.

KOMINACS, A.P. A preliminary study of the application of artificial neural networks to prediction of milk yield in dairy sheep. Computers and Eletronics in Agriculture, v.35, p.35-48, 2002.

KOVÁCS, Z.L. Redes neurais artificiais: fundamento e aplicações. 2.ed. São Paulo: Edição Acadêmica, 1996. 176p.

KRISTENSEN, K.H.; WATHES, C.M. Amônia e bem-estar das aves: uma síntese. Clipping Merial de Avicultura, v.2, n.6, p.27-32, 2001.

LARRY, D.J.; STEVE, P.; WILLIAM, G.B. Troubleshooting swine ventilation systems: pork industry handbook. Purdue: University Cooperative Extension Service, 1994. 6p.

LAWRENCE, A.B.; APPLEBY, M.C.; MACLEOD, H.A. Measuring hunger in the pig using operant conditioning: the effect of food restriction. Animal Production, v.47, n.1, p. 131-137, 1988.

LEE, A.; ULBRICHT, C.; DORFFNER, G. Application of artificial neural networks for detection of abnormal fetal heart rate pattern: a comparison with conventional algorithms. Journal of Obstetrics and Gynaecology, v.19, n.5, p.482-485, 1999.

LEITE, D.M.G.; COSTA, O.A.D.; VARGAS, G.A.V.; MILLEO, R.D.S.; SILVA, A. Análise econômica do sistema intensivo de suínos criados ao ar livre. Revista Brasileira de Zootecnia, v.30, n.2, p. 127-132, 2001.

LOPES, A.A.; PAZ, S.M.; CUGNASCA, C.E.; SARAIVA, A.M. Sharing Video Images on the Internet Using Java: An Application to Controlled Environment. In: WORLD CONGRESS OF COMPUTERS IN AGRICULTURE AND NATURAL RESOURCES, 2., Foz do Iguaçu, 2002. Proceedings. Foz do Iguaçu: ASAE, 2002. p.114-118.

LOVE, R.J.; EVAN, G.; KLUPIEC, C. Seasonal effects on fertility in gilts and sows. Journal of Reproduction Fertility, v.2, suppl.1, p.191-206, 1993.

LOVE, R.J.; KLUPIEC, C.; THORNTON, E.J.; EVAN, G. An interaction between feeding rate and season affects fertility of sows. Animal Reproduction Science, v.39, p.275-284, 1995.

MACHADO FILHO, L. C.P.; HOTZEL, M.J. Bem estar em suínos. In: SEMINÁRIO INTERNACIONAL DE SUINOCULTURA, 5., São Paulo, 2000. Anais. São Paulo: Gessuli, 2000. p.88-105. 
MAMDANI, E.H. Advances in the linguistic syntesis of fuzzy controllers. International Journal of Man-Machine Studies, v.8, p.669-678, 1976.

MARCHANT, J.N.; BROOM, D.M. Factors affecting posture-changing in loose-housed and confined gestating sows. Animal Science, v.63, n.1, p. 105-113, 1996.

McFARLANE, J.M.; BOE, K.E.; CURTIS, S.E. Turning and walking by gilts in modified gestation crates. Journal of Animal Science, v.66, n.2, p. 326-333, 1988.

McPHEE, C.P.; KERR, J.C.; CAMERON, N.D. Peri-partum posture and behaviour of gilts and the location of their piglets in lines selected for components of efficient lean growth. Applied Animal Behaviour Science, v.71, n.1, p.1-12, 2001.

MEESE, G.B.; EWBANK, R. The establishment and nature of the dominance hierarchy in the domesticated pig. Animal Behaviour, v.21, n.1, p. 326-334, 1973.

MENDL, M.; ZANELLA, A.J.; BROOM, D.M. Physiological and reproductive correlates of behavioural strategies in female domestic pigs. Animal Behaviour, v.44, p.1107-1121, 1992.

MENESES, J.F. Produção de suínos e bem-estar animal: uma perspectiva européia. In: SILVA, I.J.O. Ambiência e qualidade na produção industrial de suínos, Piracicaba: FEALQ, 1999. p.180-195.

MOORE, A.S.; GONYOU, H.W.; GHENT, A.W. Integration of newly introduced and resident sows following grouping. Applied Animal Behaviour Science, v.38, n.1, p.257-267, 1993.

MORES, N.; SOBESTIANSKY, J.; WENTZ, I.; MORENO, A.M. Manejo do leitão do nascimento até o abate. In: SOBESTIANSKY, J.; WENTZ, I.; SILVEIRA, P.R.S.; SESTI, L.A.C. Suinocultura intensiva. Concórdia: Embrapa, CNPSA, 1998. p.135161.

MOUNT, N.C.; SEABROOK, M.F. A study of aggression when group housed sows are mixed. Applied Animal Behaviour Science, v.36, n.1, p.377-383, 1993.

MOURA, D.J. Ventilação na suinocultura. In: SILVA, I.J.O. Ambiência e qualidade na produção industrial de suínos. Piracicaba: FEALQ, 1999. p.149-179.

MOURA, D.J.; NÄÄS, I.A.; SILVA, I.J.O.; SEVEGNANI, K.B.; CORRIA, M.E. The use entalpy as a thermal comfort index. In: LIVESTOCK ENVIRONMENT, 5., St. Joseph, 1997. Proceedings. St. Joseph: ASAE, 1997. v.1, p.242-248.

MUIRHEAD, M.; ALEXANDER, T. Managing pig health and the treatement of disease. Sheffield: 5Mentreprises, 1997. 608p.

NÄÄS, I.A. A influência do meio ambiente na reprodução das porcas. In: SEMINÁRIO INTERNACIONAL DE SUINOCULTURA, 5., São Paulo, 2000. Anais. Concórdia: Embrapa Suínos e Aves, 2000. p.142-151. 
NÄÄS, I.A. Estado da arte no Brasil e prospecção quanto a futuras pesquisas. In: SEMINÁRIOPOLUENTES AÉREOS E RUÍDOS EM INSTALAÇÕES PARA PRODUÇÃO DE ANIMAIS, 1., Campinas, 2002. Anais. Campinas: FEAGRI, 2002. p. 3-15.

NADER, A.; BARACHO, M.S.; NÄÄS, I.A.; SAMPAIO, C.A.P. Avaliação dos níveis de ruídos e da qualidade do ar (com relação a presença de gases e fungos) em creche de suínos. In: SEMINÁRIOPOLUENTES AÉREOS E RUÍDOS EM INSTALAÇÕES PARA PRODUÇÃO DE ANIMAIS, 1., Campinas, 2002. Anais. Campinas: FEAGRI, 2002. p. 49-56.

NAKTGEBOREN, C. Psychogene einflusse auf da kontraktionsmuster des uterus und auf den geburtsverlauf. In: INTERNATIONAL CONGRESS OF ANIMAL REPRODUCTION WITH ARTIFICIAL INSEMINATION, 7., Munich, 1972. Proceedings. Munich, 1972. p.555-560.

NATIONAL RESEARCH COUNCIL. Nutrient requeriments of swine. 10.ed. Washington, 1998. 189p.

NECOECHEA, A.R. Doenças e meio ambiente. Suinocultra Industrial, v.8, n.8, p.13$26,1986$.

NIENABER, J.A.; HAHN, L.G.; YEN, J.T. Thermal environment effects on growingfinishing swine, Part I-Growth, feed intake and heat production. Transaction of the ASAE, v.30, n.6, p.1772-1775, 1987.

NOBLET, J.; DOURMAD, J.Y.; DIVIDICH, J.; DUBOIS, S. Effect of ambient temperature and adition of straw or alfafa in the diet on energy metabolism in pregnant sows. Livestock Production Science. v.21, p.309-324. 1989.

O'CONNELL, N.E.; BEATTIE, V.E.; MOSS, B.W. Influence of replacement rate on the welfare of sows introduce to a large dynamic group. Applied Animal Behaviour Science, v.85, n.1-2, p.43-56, 2004.

OLDIGS, B.; SCHLICHTING, M.C.; ERNST, E. Trials on the grouping of sows. In: INTERNATIONAL CONFERENCE ON APPLIED ETHOLOGY IN LIVESTOCK, 23., Torremolinos, 1993. Proceedings. Torremolinos: KTBL-Schrift, 1993. p. 109120.

OLIVEIRA, R.F.M.; DONZELE, J.L., FREITAS, R.T.F.; FONSECA, F.A. Efeito da temperatura ambiente sobre o desempenho e sobre parâmetros fisiológicos e hormonais de leitões consumindo dietas com diferentes níveis de energia digestível. Revista Brasileira de Zootecnia, v.26, n.3, p.1173-1182, 1997.

OLSSON, A.; SVENDSEN, J. Mixing of sows and gilts: problems and routines. In: SWEDISH UNIVERSITY OF AGRICULTURAL SCIENCES. Report 96. Lund, 1995. p.123-136.

PEDRYEZ, W.; GOMIDE, F. An introduction to fuzzy sets: analysis and design. Cambrige: The MIT Press, 1998. 522p. 
PELTONIEMI, O.A.T.; LOVE, R.J.; HEINOMEN, M.; TUOVINEM, V.; SALONIEMI, H. Seasonal and management effects on fertility of the sow: a descriptive study. Animal Reproduction Science, v.55, p.47-61, 1999.

PERDOMO, C.C.; LIMA, G.J.M.M.; NONES, K. Produção de suínos e meio ambiente. In: SEMINÁRIO NACIONAL DE DESENVOLVIMENTO DA SUINOCULTURA, 9., Gramado, 2001. Anais. Gramado: EMBRAPA, CNPSA, 2001. p.11-17.

PEREIRA, A.R.; ANGELOCCI, L.R.; SENTELHAS, P.C. Agrometeorologia: fundamentos e aplicações práticas. Guaíba: Agropecuária, 2002. 478p.

PEREZ Y PEREZ, P.; PEREZ GUTIEREZ, J.F. Summer infertility of swine stock in Spain. Luxemburg: Commission of the European Communities, 1987. p.25-28.

PETHERICK, J.C.; BLACKSHAW, J.K. A review of the factors influencing the aggressive and agonistic behaviour of the domestic pig. Australian Journal of Experimental Agriculture, v.27, n.3, p. 605-611, 1987.

PICKRELL, J. Hazards in confinement housing: gases and dusts in confined animal houses for swine, poltry, horses and humans. Veterinary Human Toxicology, v.33, n.1, p.32-39, 1991.

PIFFER, I.A.; PERDOMO, C.C.; SOBESTIANSKY, J. Efeito de fatores ambientais na ocorrência de doenças. In: SOBESTIANSKY, J.; WENTZ, I.; SILVEIRA, P.R.S.; SESTI, L.A.C. Suinocultura intensiva. Brasília: EMBRAPA, 1998. p.255-274.

POMAR, C.; HARRIS, D.L.; SAVOIE, P.; MINVIELLE, F. Computer simulation model of swine production systems. Journal of Animal Science, v.69, n.4, p.28222836, 1991.

PRITCHARD, V. Oestrous and mating behavior in group housed sows and the effect of social dominance. Aberdeen, 1996. 145p. Thesis (MSc.) - University of Aberdeen.

ROLLER, W.L.; TEAGUE, H.S.; GRIFO Jr, A.P. Reproductive performance of swine in controlled warm environments. Transactions of the ASAE, v.10, n.4, p.517-522, 1967.

ROSSEAU, P.; CHARRIER, P.; CHOSSON, C.; GRANIER, R. Absence de renouvellement de l'air dans de module de porcherie experimentale: Evolution des parametres climatiques et physiologiques. Journées de la Recherche Porcine en France, v.21, p.253-260. 1989.

ROSSING, W. Animal identification: introduction and history. Computers and Electronics in Agriculture, v.24, n.1, p.1-4, 1999.

ROUSH, W.B.; KIRBY, Y.K.; CRAVENER, T.L.; WIDEMAN JR, R.F. Artificial neural network prediction of ascite in broilers. Poultry Science, v.75, p.1479-1487, 1996.

ROUSH, W.B.; CRAVENER, T.L. Artificial neural network prediction of amino acid levels in feed ingredients. Poultry Science, v.76, n. 5, p.721-727, 1997. 
ROUSH, W.B.; CRAVENER, T.L.; KIRBY, Y.K.; WIDEMAN JR, R.F. Probabilistic neural network prediction of ascite in broilers based on minimally invasive physiological factors. Poultry Science, v.76, p.1513-1516, 1997.

RUDKIN, C.; STEWART, G.D. Behaviour of hens in cages: a pilot study using video tapes. A Report for the Rural Industries Research and Development Corporation, v.40,n.477, p.102, 2003.

SAINBURY, D.W.B. Climatic environment and pig performance. In: COLE, D.J.A. (Ed.). Pig production. London: Butterworths, 1972. p.91-105.

SALIBA, T.M.; CORREAA, M.A.C. Manual prático de avaliação e controle de gases e vapores. São Paulo: Ed. LTR, 2000. 132p.

SAMPAIO, C.A.P. Caracterização dos sistemas térmicos e acústicos em sistemas de produção de suínos nas fases de creche e terminação. Campinas, 2004. 121p. Tese (doutorado) - Faculdade de Engenharia Agrícola UNICAMP.

SANDRI, S.; CORREA, C. Lógica Nebulosa. In: ESCOLA DE REDES NEURAIS: CONSELHO NACIONAL DE REDES NEURAIS, 5, São José dos Campos, 1999. Anais. São José dos Campos: ITA, 1999. p.73-90.

SARUBBI, J. Importância do selo suíno paulista para a saúde animal. http://www.apcs.com.br/7,1,26,5191.asp. (15 abr. 2005).

SAS INSTITUTE, Statistical analysis system: realease 6.08, (software). Cary, 1992. $620 \mathrm{p}$.

SCHOUTEN, W.G.P.; LENSINK, J.; LAKWIJK, N.; WIEGANT, V.M. De-arousal effect of stereotypies in tethered sows. In: INTERNATIONAL CONGRESS ISAE, 34., Madri, 2000. Proceedings. Madri: ISAE, 2000. p.46.

SHAO, J.; XIN, H.; HARMON, J.D. Neural network analysis of postural behavior of young swine to determine their thermal comfort state. Transactions of the ASAE, v.40, n.3, p.755-760, 1997.

SHAO, J.; XIN, H.; HARMON, J.D. Comparison of image feature extraction for classification of swine thermal comfort behavior. Computer and Electronics in Agriculture, v.19, p.223-232, 1998.

SILVA, I.J.O. Qualidade do ambiente e instalações na produção industrial de suínos. In: SIMPÓSIO INTERNACIONAL DE SUINOCULTURA, São Paulo, 1999. Anais. São Paulo: Gessuli, 1999. p.108-325.

SILVA, R.G. Tópicos especiais em construções rurais e ambiência: notas de aula. Campinas: FEAGRI, 1995. 98p.

SORENSEN, P.H. Influencia del ambiente climático en la production del cerdo. In: MORGAN, J.T. (Org.). Nutricion de aves y cerdos. Zaragoza: Ed. Acribia, 1964. p.7-116. 
SPOOLDER, H.A.M.; BURBIDGE, J.A.; EDWARDS, S.A.; SIMMINS, P.H.; LAWRENCE, A.B. Provision of straw as a foraging substrate reduces the development of excessive chain and bar manipulation in food restricted sows. Applied Animal Behaviour Science, v.43, n.3, p. 249-262, 1995.

SPOOLDER, H.A.M.; BURBIDGE, J.A.; EDWARDS, S.A.; LAWRENCE, A.B.; SIMMINS, P.H. Social recognition in gilts mixed into a dynamic group of 30 sows. Animal Science, v.62, n.1, p. 630, 1996.

STEIGER, A. Ethologische beuteilung der aufstallungssysteme in der schweinemast. In: WORLD CONGRESS ON ETHOLOGY APPLIED TO ZOOTECHNICS, 1., Madri, 1978. Anais. Madri: Garsi, 1978. p.227-234.

STOLBA, A.; BAKER, N.; WOOD-GUSH, D.G.M. The characterization of stereotyped behavior in stalled sows by informational redundancy. Behaviour, v.77, n.1, p.157$81,1983$.

STOLBA, A.; WOOD-GUSH, D.G.M. The behaviour of pigs in a semi-natural environment. Animal Production, v. 48, p.419-425, 1989.

TAKAI, H.; PEDERSEN, S.; JOHNSEN, J.O.; METZ, J.H.M.; KOERKAMP, P.W.G.; UENK, G.H.; PHILLIPS, V.R.; HOLDEN, M.R.; SNEATH, R.W.; SHORT, J.L.; WHITE, R.P.; HARTUNG, J.; SEEDORF, J.; SCHRÖRDER, M.; LINKERT, K.H.; WATHES, C.M. Concentration and emissions of airbourne dust in livestock buildings in northern Europe. Journal of Agricultural Engineering Research, v.70, n.1, p.59-77, 1998.

TAVARES, M.; OLIVEIRA, R.F.M.; DONZELE, J.L.; FERREIRA, A.S. Influência da temperatura ambiente sobre o desempenho e os parâmetros fisiológicos de leitões dos 30 aos 60 kg. Revista Brasileira de Zootecnia, v.28, n.2, 791-798, 1999.

TAYLOR, L.; FRIEND, T.; SMITH, L.A. Effects of housing on in situ postures of gestating gilts. Applied Animal Behaviour Science, v.19, n.2, p. 265-272, 1988.

TE BRAKE, J.H.A.; BRESSERS, H.P.M. Applications in service management and oestrus detection. In: INTERNATIONAL SYMPOSIUM ON ELECTRONIC IDENTIFICATION IN PIG PRODUCTION, 1., Stoneleigh, 1990. Proceedings. Stoneleigh: RASE, 1990. p. 63-67.

VAN DER LENDE. Embryo mortality and prolificacy in the pig. In: COLE, D.J.A.; WISEMAN, J.; VARLEY, M.A. Principles of pig science. Longhborough: Nothingan University Press, 1994. 472p.

VAN PUTTEN, G.; VAN de BURGWAL, J.A. Vulva biting in group-housed sows: a preliminary report. Applied Animal Behaviour Science, v.26, n.1, p. 181-186, 1990.

VEIT, H.P.; TROUTT, H.F. Monitoring air quality for livestock respiratory health. Veterinay Medicine and Small Animal Clinician, v.77, p.454-464, 1982. 
VERSTEGEN, M.; TAMMINGA, S.; GREERS, R. The effect of gaseous pollutants on animals. In: DEWI, I.A. Polution in livestock production systems. Amsterdam: CAB International, 1994. p.422-463.

VERSTEGEN, M.W.A.; CLOSE, W.H. The environment and the growing pig. In: COLE, D.J.A.; WISEMAN, J.; VARLEY, M.A. Principles of pig science. Longhborough: Nothingan University Press, 1994. p.257-289.

VIEIRA, H.P.; VIEIRA, R.P. Definition of the summer infertility problem in the pig. Luxemburg: Commission of the European Communities, 1987. 35p.

VIEUILLE-THOMAS, C.; LE PAPE, G.; SIGNORET, J.P. Stereotypies in pregnant sows: indication of influence of the housing system on the patterns expressed by the animals. Applied Animal Behaviour Science, v.44, n.1 ,p.19-27, 1995.

VON BORELL, E. Neuroendocrine integration of stress and significance of stress for the performance of farm animals. Applied Animal Behaviour Science, v.44, p.219$227,1995$.

WARRISS, P. D. Meat science: an introductory text. Wallingford: CABI Publishing, 2000. 310p.

WEARY, D.M.; APPLEBY, M.C.; FRASER, D.Response of piglets to early separation from the sow. Applied Animal Behaviour Science, v. 63, n.2, p.289-300, 1999.

WEBSTER, A.J.F. The challenge of animal welfare. In: WORLD CONFERENCE ON ANIMAL PRODUCTION, Edmonton, 1993. Proceedings. Edmonton: AB Canada, 1993. p. 513-524.

WENTZ, I.; BORTOLOZZO, F.P.; BARCELLOS, D.E.S.N.; JACOBI, H. Ocorrência de síndrome de aborto em suínos no Rio Grande do Sul. In: CONGRESSO BRASILEIRO DE VETERINÁRIOS ESPECIALISTAS EM SUÍNOS, Foz do Iguaçu,1997. Anais. Foz do Iguaçu: Abraves, 1997. p.301-302.

WHITTAKER, X.; SPOOLDER, H.A.M.; EDWARDS, S.A.; LAWRENCE, A.B.; CORNING, S. The influence of dietary fibre and the provision of straw on the development of stereotypic behaviour in food restricted pregnant sows. Applied Animal Behaviour Science, v.61, n.1, p. 89-102, 1998.

WHITTAKER, X.; EDWARDS, S.A.; SPOOLDER, H.A.M.; LAWRENCE, A.B.; CORNING, S. Effects of straw bedding and high fibre diets on the behaviour of floor-fed group-housed sows. Applied Animal Behaviour Science, v.63, n.1/2, p. 25-39, 1999.

WHITTEMORE, C.T. Causes and consequences of change in the mature size of the domestic pig. Outlook Agriculture, v.23, p.55-59, 1994.

WISMANS, W.M.G. Identification and registration of animals in the European Union. Computers and Eletronics in Agriculture, v.24, n.2, p.99-108, 1999. 
WOUTERS, P.; GEERS, R.; PARDUYNS, G.; GOOSSENS, K.; TRUYEN, B.; GOEDSEELS, V.; VAN DEER STUYFT, E. Image analysis parameters as inputs for automatic environmental temperature control in the piglets houses. Computers and Electronics in Agriculture, v.5, n.2, p.233-246,1990.

XIN, H. Assessing swine thermal comfort by image analysis of postural behaviors. Journal of Animal Science, v.77, n.1, suppl. 2, p.1-9, 1999.

XIN, H.; SHAO, J Real-time Assessment of Swine Thermal Comfort by Computer Vision. In: WORLD CONGRESS OF COMPUTERS IN AGRICULTURE AND NATURAL RESOURCES, 2., Foz do Iguaçu, 2002. Proceedings. Foz do Iguaçu: ASAE, 2002. p.362-369.

XIN, H.; GATES, RS.; WHELLER, EF. Quantification of ammonia emissions from U.S. poultry houses. In: SEMINÁRIO DE POLUENTES AÉREOS E RUÍDOS EM INSTALAÇÕES PARA PRODUÇÃO DE ANIMAIS, Campinas, 2002. Anais. Campinas: FEAGRI, 2002. p. 25-32.

XIN, J.; BECK, H.; HALSEY, L.; FLETCHER, J.; ZAZUETA, F. Using Digital Cameras and the Internet to Identify Plant Insect and Disease Problems. In: INTERNATIONAL CONFERENCE ON COMPUTERS IN AGRICULTURE, 17., Orlando, 1998. Proceedings. Orlando: ASAE, 1998. p.327-329.

YAN, P.S.; YAMAMOTO, S. Relationship between thermoregulatory responses and heat loss in piglets. Journal of Animal Science, v.71, n.10, p.5005-509, 2000.

ZADEH, L.A. Fuzzy sets. Information and Control, v.18, p. 338-353, 1965.

ZADEH, L.A. Outiline of a mew approach to the analysis of complex system and decision processes. IEEE Transactions on System, Man and Cybernetics, v.3, p.25-44, 1973.

ZONDERLAND, J.J.; LEEUW, J.A.; NOLTEN, C.; SPOOLDER, H.A.M. Assessing long-term behavioural effects of feeding motivation in group-housed pregnant sows; what, when and how to observe. Applied Animal Behaviour Science, v.87, n.1-2, p.15-30, 2004.

ZURADA, J.M. Introduction to artificial neural systems. St. Paul: West Publishing Company, 1992. 683p. 